Ostracodes from Lower Devonian Formations in Alaska and Yukon Territory

GEOLOGICAL SURVEY PROFESSIONAL PAPER 825

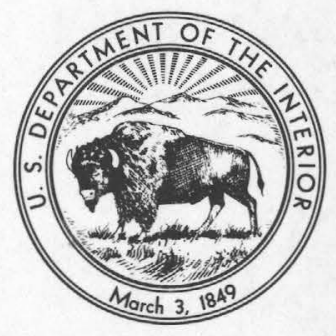




\section{Ostracodes from Lower Devonian Formations in Alaska and Yukon Territory}

By JEAN M. BERDAN and M. J. COPELAND

GE OLOGICAL S U R VEY PROFESSIONAL PAPER 825

Descriptions and illustrations of an ostracode assemblage comprising 73 taxa, including 6 new genera and 33 new species, of potential value for regional correlation in the Arctic province

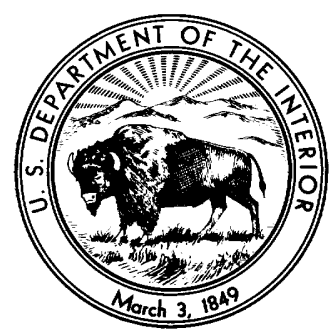




\section{UNITED STATES DEPARTMENT OF THE INTERIOR \\ ROGERS C. B. MORTON, Secretary}

\section{GEOLOGICAL SURVEY}

V. E. McKelvey, Director

Library of Congress catalog-card No. 73-600212

For sale by the Superintendent of Documents, U.S. Government Printing Office Washington, D.C. 20402 - Price $\$ 1.75$ (paper cover)

Stock Number 2401-02407 


\section{CONTENTS}

Abstract

Introduction

Acknowledgments -..--

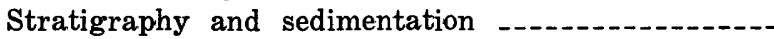

Age and correlation

List of localities

Systematic paleontology

Order Palaeocopida

Genus Mesomphalus Ulrich and Bassler, 1913

Genus Treposella Ulrich and Bassler, 1908

Genus Beyrichia M'Coy, 1846

Genus Yukonibeyrichia n. gen

Genus Alaskabolbina n. gen -..........-

Genus Ogilvites n. gen

Genus Abditoloculina Kesling, 1952 -..--.-

Genus Parabolbina Swartz, 1936

Genus Hollina Ulrich and Bassler, 1908 ...-

Genus Falsipollex Kesling and McMillan, 1951

Genus Hollinella Coryell, 1928

Genus Abortivelum n. gen -........-.--

Genus Adelphobolbina Stover, 1956 .......-

Genus Flaccivelum Kesling and Peterson, 1958

Genus Infractivelum $\mathrm{n}$, gen

Genus Chironiptrum Kesling, 1952

Genus Obotritia Adamczak, 1968 ........-

Genus Kirkbyella Coryell and Booth, 1933 -

Genus Hanaites Pokorný, 1950 ...-.-.-.--

Genus Subarctichites n. gen

Genus Libumella Rozhdestvenskaya, 1959 ..

Genus Neoaparchites Bouček, 1936

Genus Aparchites Jones, 1889

Genus Eukloedenella Ulrich and Bassler, 1923

Genus Poloniella Gürich, 1896

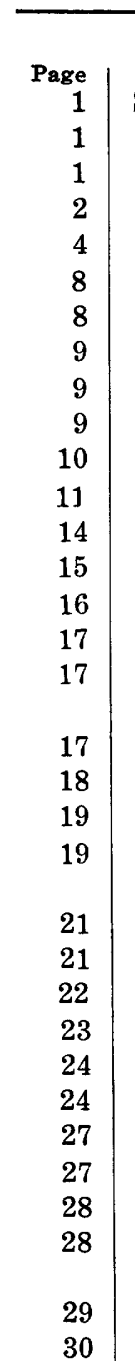

Systematic paleontology-Continued

Order Podocopida - 30

Genus Bairdia M'Coy, 1844 -..- 30

Genus Rectobairdia Sohn, 1961 --------- 31

Genus Bairdiolites Croneis and Gale, 1939_- 31

Genus Newsomites Morris and Hill, 1952 -- 31

Genus Acanthoscapha Ulrich and Bassler,

1923 -

Genus Shidelerites Morris and Hill, 1951 -.- $\quad 32$

Genus Beecherella Ulrich, 1891 _..--_---- 33

Genus Camdenidea Swain, 1953

Genus Tricornina Bouček, 1936 _.....-.- 33

Genus Bicornina Jordan, 1964 _._-_-_-- 34

Genus Berounella Bouček, 1936 ...-.-.-.-- 34

Genus Bairdiocypris Kegel, 1932 _..-_-- 35

Genus Kuresaaria Adamczak, 1967 ....-. 35

Genus Bairdiohealdites McGill, 1968 -.--- $\quad 36$

Genus Praepilatina Polenova, 1970 -..--- $\quad 36$

Genus Barychilina Ulrich, 1891 ........- 36

Genus Trypetera Kesling, 1954 -..--_-_- $\quad 37$

Genus Voronina Polenova, 1952 _.-.-_-_- $\quad 37$

Genus Cavellina Coryell, 1928 _..-_-.--- 37

Genus Tubulibairdia Swartz, 1936 .....-.- 38

Pachydomellid indet. 1 _-_._-_.-.- 38

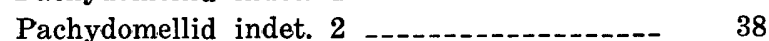

Genus Eriella Stewart and Hendrix, 1945 -- 39

Genus Neocraterellina Krandijevsky, 1968 -- $\quad 39$

Genus Microcheilinella Geis, 1933 _._._-_. $\quad 39$

Ostracode indet. 1 - 40

Ostracode indet. 2 -

Ostracode indet. 3 -..-..- 40

References cited -

Index _....- 45

\section{ILLUSTRATIONS}

[Plates follow index]

Plate 1. Mesomphalus? and Treposella.

2. Beyrichia (Beyrichia).

3. Beyrichia (Scabribeyrichia).

4. Yukonibeyrichia.

5. Alaskabolbina and Alaskabolbina?

6. Ogilvites, Abditoloculina, Abortivelum, Adelphobolbina, and Hollina.

7. Hollinella, Adelphobolbina, and Falsipollex?.

8. Obotritia?, Chironiptrum, Flaccivelum, Parabolbina, and Infractivelum.

9. Kirkbyella, Hanaites, and Subarctichites.

10. Libumella, Neoaparchites?, and "Aparchites." 
Plate 11. Bairdia, Bairdiolites?, Beecherella?, Acanthoscapha, Rectobairdia, Shidelerites, Eukloedenella, and Poloniella (Framella).

12. Tricornina, Bicornina, Berounella, Bairdiocypris?, Bairdiocypris, and Kuresarria.

13. Camdenidea, Praepilatina, Bairdiohealdites?, and Voronina.

14 Eriella?, Microcheilinella?, Neocraterellina?, Cavellina (Invisibila)?, Newsomites?, Barychilina?, Trypetera?, Tubulibairdia, and ostracodes indet.

Figure 1. Index map showing locations of sections from which ostracodes were collected in Alaska and Yukon Territory

2. Diagrammatic sections of the McCann Hill Chert and Michelle and Prongs Creek Formations showing positions of ostracode collections -

3-7. Scatter diagrams showing length versus height of :

3. Beyrichia (Beyrichia) brabbi

4. Beyrichia (Scabribeyrichia) churkini

5. Yukonibeyrichia yukonensis

6. Chironiptrum limitaris -

7. Hanaites brevis

Page

TABLE

TABLE 1. Ostracode taxa described in this paper and the formations and collections in which they occur 


\title{
OSTRACODES FROM LOWER DEVONIAN FORMATIONS IN ALASKA AND YUKON TERRITORY
}

\author{
By Jean M. Berdan and M. J. Copeland ${ }^{1}$
}

\begin{abstract}
Residues of samples, dissolved in acetic and formis acid from the limestone and shale member of the McCann Hill Chert of eastern Alaska and the Michelle and Prongs Creek Formations of Yukon Territory have revealed the presence of a varied, silicified ostracode fauna. This fauna may serve as a basis for correlating strata from the Alaska-Yukon international boundary near lat $65^{\circ} \mathrm{N}$. northeastward for more than 200 miles.

Of the more than 40 genera present, hollinaceans and beyrichiaceans are the most distinctive. The hollinaceans find their closest affinity with genera from lower Middle Devonian (Eifelian) beds from the midcontinent region of North America, and the beyrichiaceans with genera from Lower Devonian and Silurian strata of Appalachian North America and of Europe. Conodonts and dacryoconarid tentaculites indicate that the age of the collections from which the ostracodes were abtained is late Early Devonian (Emsian), but the ostracode assemblage reported here does not resemble any described Emsian fauna.

These ostracodes are considered to represent a provincial assemblage with some Silurian survivors and some precursors of Middle Devonian forms which subsequently migrated to Eurasia and central North America. In all, 73 taxa, including 6 new genera and 33 new species, are described and illustrated.
\end{abstract}

\section{INTRODUCTION}

The McCann Hill Chert of Alaska and the Michelle and Prongs Creek Formations of Yukon Territory, Canada, contain a large fauna of invertebrate fossils which includes a varied and abundant assemblage of ostracodes. Some of the silicified ostracodes from the McCann Hill Chert have been listed and illustrated by Berdan (in Churkin and Brabb, 1967), and silicified ostracodes from the Michelle and Prongs Creek Formations have been listed by Copeland (in Ludvigsen, 1970). Copeland (in Norris, 1967a, sections 16,17, and 19) also reported several nonsilicified specimens from the Michelle Formation in the vicinity of Hart and Blackstone Rivers, Yukon Territory. The present paper is the first comprehensive description of the silicified ostracode assemblage from these formations.

\footnotetext{
${ }^{1}$ Geological Survey of Canada, Ottawa, Ontario, Canada.
}

The first of the silicified ostracode faunules was found in USGS collection 6492-SD, from the basal limestone and shale member of the McCann Hill Chert, one half mile west of Hillard Peak, Alaska, and 3.4 miles N. $41^{\circ} \mathrm{W}$. of International Boundary Commission monument $105,\left(64^{\circ} 57^{\prime} 03^{\prime \prime}\right.$ N., $141^{\circ} 04^{\prime} 05^{\prime \prime}$ W.). From this collection, Berdan (in Churkin and Brabb, 1967, table 1, pl. 4) reported 20 species belonging to 18 genera, and illustrated 14 of these species. Later, similar silicified ostracodes were obtained by Ludvigsen (1970) from five sections ( $\mathrm{I}-\mathrm{V})$ in Yukon Territory, from the Michelle Formation of Blackstone and Hart Rivers (about $65^{\circ} 41^{\prime}$ N., $137^{\circ} 00^{\prime}$ W.) and the Prongs Creek Formation of Solo Creek $\left(65^{\circ} 51.4^{\prime}\right.$ N., $134^{\circ} 15.5^{\prime}$ W. $)$. Copeland (in Ludvigsen, 1970, p. 426) listed 10 species of 9 genera from each of the Michelle and Prongs Creek Formations. In all, the present authors previously recognized 19 known and 2 unnamed ostracode genera. Further study of the original and additional collections has resulted in this report, in which 73 ostracode taxa are described and illustrated. Of these, 6 genera and 33 species are new.

The ostracode occurrences are scattered from near the Alaska-Yukon international boundary at lat $65^{\circ}$ N. for more than 200 miles northeastward to eastern Yukon Territory (fig. 1). Although many of the species are known as yet from only one collection or locality, some of them are widely distributed, and the similarity of the ostracodes on the generic level suggests that they are approximately the same age. The silicified specimens described here may serve as a basis for widespread correlation within the Yukon Shelf of Alaska and Yukon Territory and, in Yukon, across the trough of the Richardson Mountains. Some of the taxa are similar to described species from the Devonian of Asiatic and European parts of the U.S.S.R. and may indicate routes of migration during the Devonian.

\section{ACKNOWLEDGMENTS}

We are grateful to R. Ludvigsen, Calgary, Alberta, for permission to describe the ostracode faunules 


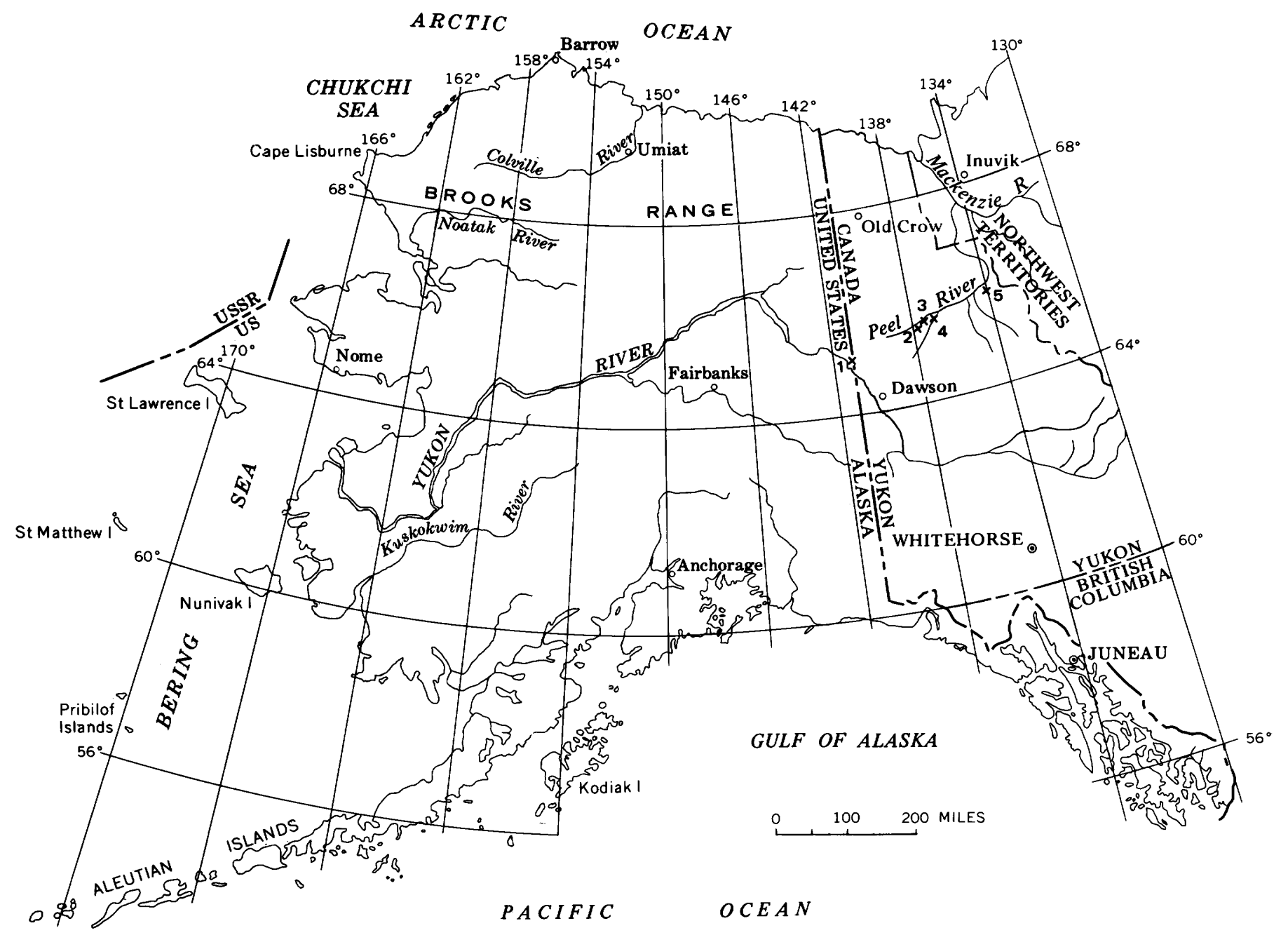

Figure 1.-Locations of measured sections from which ostracodes have been collected in Alaska and Yukon Territory. 1, Type section of McCann Hill Chert described by Churkin and Brabb (1965); 2, sections II and III of the Michelle Formation described by Ludvigsen (1970); 3, section IV of the Michelle Formation described by Ludvigsen (1970); 4, section I of the Michelle Formation described by Ludvigsen (1970); 5, section V of the Prongs Creek Formation described by Ludvigsen (1972).

obtained by him in Yukon Territory during the summer of 1968 while he was employed by Gulf Oil, Canada, Limited. Appreciation is expressed to $\mathrm{R}$. Ludvigsen, to A. C. Lenz, University of Western Ontario, and to A. W. Norris, Geological Survey of Canada, for revision and comments on the Canadian stratigraphic part of the paper, and to Michael Churkin, Jr., E. E. Brabb, and J. T. Dutro, Jr., all of the U.S. Geological Survey, for review of the Alaskan stratigraphic part of the paper. I. G. Sohn, U.S. Geological Survey, and Thomas E. Bolton, Geological Survey of Canada, critically reviewed the manuscript.

\section{STRATIGRAPHY AND SEDIMENTATION}

Throughout the area under discussion, strata of the McCann Hill Chert and Michelle and Prongs
Creek Formations overlie graptolitic shale of the Road River Formation containing Monograptus yukonensis Jackson and Lenz, 1963, which according to Jaeger $(1970$, p. 174-175) is Early Devonian in age (Siegenian? to possibly late Emsian). In the west, the contact of the McCann Hill Chert with the Road River Formation appears to be accordant in the section from which the ostracodes were obtained, although there is possible evidence of a stratigraphic break between the formations-a single cobble of graptolitic shale in the basal McCann Hill Chert (Churkin and Brabb, 1965, p. 181; 1967, p. 231). According to Ludvigsen (1970, p. 412), in the Hart River-Blackstone River area, the Michelle Formation has a gradational contact with the Road River Formation, although Norris (1967b, p. 758) suggested that the contact may be unconformable. The 
contact of the Prongs Creek Formation with the Road River in the Solo Creek area has not been described in detail, but in the area that includes Solo Creek, Norris $(1967 b$, p. 770$)$ stated that the contact is within shales and was tentatively drawn above the highest vccurrence of monograptids, although farther north at Trail River the contact is an erosional unconformity. Ludvigsen $(1972$, p. 302) also drew the contact of the Road River and Prongs Creek immediately above the highest occurrence of graptolites.

The McCann Hill Chert in its type section, from which the ostracodes described in this report were obtained, is abruptly overlain by the lowermost sandstone beds of the Nation River Formation (Upper Devonian). According to Churkin and Brabb (1965, p. $181 ; 1967$, p. 232-233) there is no evidence for a stratigraphic break at the contact, and the upper part of the McCann Hill contains spores similar to those in the overlying Nation River; consequently, the formations are probably conformable. The Michelle Formation is overlain by the Ogilvie Formation in the Hart River-Blackstone River area; the contact is sharp and may represent a disconformity (Norris, 1967b, p. 770; Ludvigsen, 1970, p. 412; 1972, fig. 2). The Ogilvie is considered to be Early and Middle Devonian in age by Ludvigsen (1972, fig. 2). The section from which ostracodes were obtained in the Prongs Creek Formation is incomplete, and the contact of the Prongs Creek with the overlying formation is unknown. Norris (1967b, fig. 4) postulated a change of facies in the area in which this section occurs.

The regional relationships and correlation of the McCann Hill Chert and the Michelle and Prongs Creek Formations have been discussed by Churkin and Brabb (1967), Lenz (1967, 1972), Norris (1967b), and Ludvigsen (1972). Details about the type locality of the McCann Hill Chert and the associated faunas are given by Churkin and Brabb (1965, p. 184, figs. 2,4$)$; the locality is also shown on a geologic map of the Eagle (D-1) quadrangle, Alaska (Brabb and Churkin, 1965). Details of many sections of the Prongs Creek and Michelle Formations in Yukon Territory have been described by Norris (1967a, 1968).

The general character of the lithologies of the McCann Hill Chert and the Michelle and Prongs Creek Formations in the sections from which ostracodes are described in this report and the stratigraphic position of the collections within the sections are shown in figure 2. The McCann Hill Chert is a 200- to 1,000-foot-thick sequence of thinly bedded, laminated light-gray to black chert alternating with siliceous shale and shale, and has a 250 -footthick limestone and shale member at its base (Churkin and Brabb, 1965, p. 180, 181). The basal limestone and shale member, from which the ostracodes were obtained, consists of lenticular beds of darkgray bioclastic limestone interbedded with darkgray to grayish-black calcareous shale, siltstone, chert grit, and laminated limestone (Churkin and Brabb, 1965, p. 180). According to Ludvigsen (1970, p. 410,412 ), in the three sections from which collections were made, the Michelle Formation "consists of moderately resistant, grey and buff-orange weathering, platy to thick-bedded argillaceous limestone with minor non-argillaceous limestone and calcareous shale." The argillaceous limestone is dark gray to black, micrograined to very fine grained, and some beds are fetid. The Prongs Creek Formation on Solo Creek is "a drab sequence of unfossiliferous, black, calcareous shales with interspersed lenses and beds of breccia composed of limestone, dolomite, or completely replaced by silica" (Ludvigsen, 1972, p. 302). These fossiliferous breccias are considered by Norris (1968, p. 23) and Ludvigsen (1972, p. 302) to have been deposited by turbidity currents.

Hand specimens of the McCann Hill Chert, from its type section, that have yielded silicified ostracodes (USGS collns. 6492-SD, 7032-SD, and 7033SD) are gray bituminous bioclastic limestone in which many of the megafossils are broken, suggesting a high-energy environment. Two samples from the McCann Hill (USGS collns. 7037-SD and 7038SD), which were collected from outcrops 300 feet east of the type section and are therefore not shown on figure 2, are also bioclastic but are more siliceous and include a considerable amount of chert. These samples were described as being from thin beds of limestone conglomerate in a shale sequence (Brabb, written commun., 1963). In one of these collections, USGS collection 7037-SD, the ostracodes are in general smaller; many juvenile specimens occur, and also many species that have not been found in the other collections. USGS collection 7038-SD, which is only 5 feet higher than USGS collection 7037-SD, contains virtually the same assemblage as in USGS collections 6492-SD, 7032-SD, and 7033-SD from about 10 feet of the type section. The differences between the ostracode assemblage in USGS collection 7037-SD and that in the other collections is believed to be due to local facies control rather than different stratigraphic position.

Hand specimens of Ludvigsen's collections from the Michelle and Prongs Creek Formations were not available for study. 


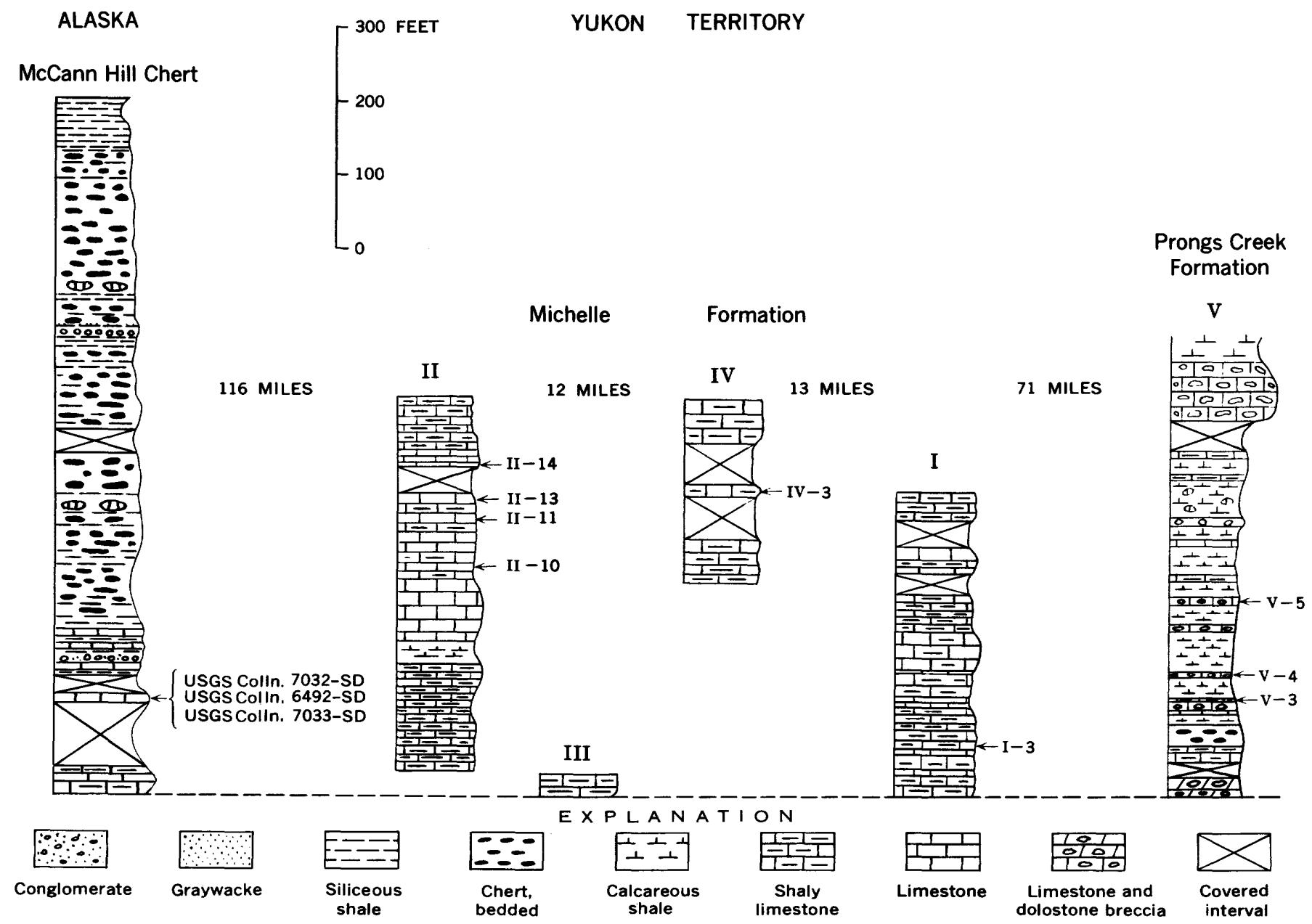

Figure 2.-Diagrammatic sections showing generalized lithology of the McCann Hill Chert, Michelle Formation, and Prongs Creek Formation and positions of ostracode collections. Sections are arbitrarily arranged with reference to the top of the underlying Road River Formation, as determined by Churkin and Brabb in Alaska and Ludvigsen in Yukon Territory; overlying formations not shown. Adapted from Churkin and Brabb (1965, fig. 4, section 5), Fåhraeus (1971, fig. 2), and Ludvigsen (1972, fig. 5).

\section{AGE AND CORRELATION}

The McCann Hill Chert and Michelle and Prongs Creek Formations contain a wide and varied fauna of invertebrates and vertebrates. Churkin and Brabb (1967) listed and illustrated some of the fossils from the McCann Hill Chert, and Churkin and Carter (1970) described the tentaculite fauna. In addition, Ormiston (1969) described a trilobite from the lower limestone and shale member of the McCann Hill Chert (USGS colln. 6492-SD). Ludvigsen (1970) discussed the fauna and illustrated brachiopods and tentaculites from the Michelle Formation and later (Ludvigsen, 1972) described the dacryoconarid tentaculites from the Michelle and Prongs Creek Formations. Stearn and Mehrota (1970) described the stromatoporoids of the Michelle and Prongs Creek Formations, Ormiston (1971) de- scribed the trilobites from the Michelle Formation, and Fåhraeus (1971) described the conodonts from the Michelle and Prongs Creek Formations. The ages of the three formations have been assigned largely on the basis of the conodonts and the dacryoconarid tentaculites.

The McCann Hill Chert fauna (USGS colln. 6492SD) of ostracodes, bryozoans, trilobites, brachiopods, pelecypods, conodonts, and tentaculitids listed by Churkin and Brabb (1967, p. 232-233) was considered by them to be Emsian (late Early Devonian) in age and to correlate with the upper part of the Salmontrout Limestone of the Porcupine-Salmontrout Rivers area, Alaska. A probable late Emsian Age for USGS collection 6492-SD is suggested by the occurrence of the tentaculitid Nowakia barrandei Boucek and Prantl, reported from this collection by Churkin and Carter $(1970$, p. 63), which, accord- 
ing to Bouček $(1967$, p. 1278), is typical of "uppermost Zlichovian or even of very basal Eifelian" beds in Bohemia. Huddle (in Ormiston, 1969, p. 1210 1211) reported the late Emsian conodont Polygnathus foveolatus Philip and Jackson from the same collection, and Klapper and others (1971, fig. 1) showed the basal McCann Hill as late Emsian and correlated it with the Blue Fiord Formation of Devon Island in the Canadian Arctic Archipelago and the upper Eurekaspirifer pinyonensis Zone of Nevada. Ormiston (1969, p. 1211-1212) considered the trilobite Koneprusia sp. from USGS collection 6492-SD to be most like K. subterarmata (Barrande) from the upper Emsian of the Harz region in Germany. In addition, USGS collection 6492-SD contains the two-holed crinoid ossicle Gasterocoma? bicaula Johnson and Lane, which Johnson and Lane $(1969$, p. 70$)$ considered late Emsian to Eifelian in age. Corals from the limestone and shale member of the McCann Hill which were considered Middle Devonian by Oliver (in Churkin and Brabb, 1965, p. 181) do not come from the same localities as the ostracodes described here.

The Michelle Formation fauna of brachiopods, tentaculites, nautiloids, trilobites, conodonts, and ostracodes was discussed and the brachiopods and tentaculites were illustrated by Ludvigsen (1970), who evaluated it as follows: (1) brachiopods indicate at least partial contemporaneity with those of the Eurekaspirifer pinyonensis Zone (Emsian) of Nevada; (2) the tentaculite fauna is tentatively correlated with the Guerichina strangulata Zone of late Praguian (early Emsian) Age in Bohemia; (3) trilobites indicate an undifferentiated Emsian Age, with no forms indicative of the late Emsian; (4) conodonts indicate correlation with the Polygnathus lenzi fauna of early Emsian Age. This assessment indicates that the age of the Michelle Formation is Emsian and possibly early Emsian. Later, Fåhraeus (1971) described and illustrated the conodonts from Ludvigsen's collections from both the Michelle and Prongs Creek Formations. Fåhraeus (1971, p. 670 671) concluded that the Michelle collections were late early Emsian (late Praguian) in age, because of the presence of Polygnathus dehiscens Philip and Jackson, which he considered a senior synonym of $P$. lenzi Klapper. He noted that the highest collection (V-5, fig. 2) from the Prongs Creek Formation on Solo Creek also contained $P$. dehiscens, implying a correlation between this part of the Prongs Creek and the Michelle. Ludvigsen (1972) described the dacryoconarid tentaculites from the Michelle and Prongs Creek Formations and concluded that they indicated an early Emsian Age, he cautioned (Ludvigsen, 1972 , p. 303), however, that a straightforward correlation with the Bohemian succession cannot be made because of the overlapping teilzones in the Michelle of the Praguian tentaculite Turkestanella acuaria (Richter) and the Zlichovian Nowakia parabarrandei.

An undifferentiated Emsian Age was suggested by House (in House and Pedder, 1963, p. 508) for the goniatite Teicherticeras lenzi from beds later included by Norris (1967b, p. 759) in the Michelle Formation. The two-holed crinoid ossicle Gasterocoma? bicaula of late Emsian to Eifelian Age, which occurs in the limestone and shale member of the McCann Hill Chert, has also been reported from the Prongs Creek Formation (Norris, 1967b, p. 770) and the Michelle Formation (Ludvigsen, 1970, p. 427) but also occurs abundantly in the overlying Ogilvie Formation (Norris, 1967b, p. 773).

In summary, previously described fossils suggest that the limestone and shale member of the McCann Hill Chert, the Michelle Formation, and the Prongs Creek Formation are all Emsian in age. Conodonts and dacryoconarid tentaculites indicate that Churkin and Brabb's collections from the limestone and shale member of the McCann Hill are late Emsian and that Ludvigsen's collections from the Michelle and Prongs Creek are early Emsian.

The silicified ostracodes obtained by Churkin and Brabb are from five collections from the limestone and shale member in the type area of the McCann Hill Chert; two collections from the measured section are about 10 feet apart stratigraphically and about 140 to 150 feet above the base of the formation. Those obtained by Ludvigsen are from (1) six collections from the Michelle Formation, four of which, from one locality on the east side of the Blackstone River (Ludvigsen collections II-10 to 14, fig. 2), span a stratigraphic thickness of about 175 feet, starting about 300 feet above the base of the formation; and (2) three collections from the Prongs Creek Formation on Solo Creek which span a stratigraphic interval of about 140 feet, starting about 150 feet above the base of the formation. The ostracode taxa described in this paper and the collections in which they occur are listed in table 1.

Of the 73 ostracode taxa listed in table 1,51 have been found in the collections from the McCann Hill Chert, 28 in the collections from the Prongs Creek Formation, and 17 in collections from the Michelle Formation. Of the total number, 18 are represented by only 1 specimen and are therefore not significant for correlation between the formations; 6 of these 
TABLE 1.-Ostracode taxa described in this paper and the formations and collections in which they occur

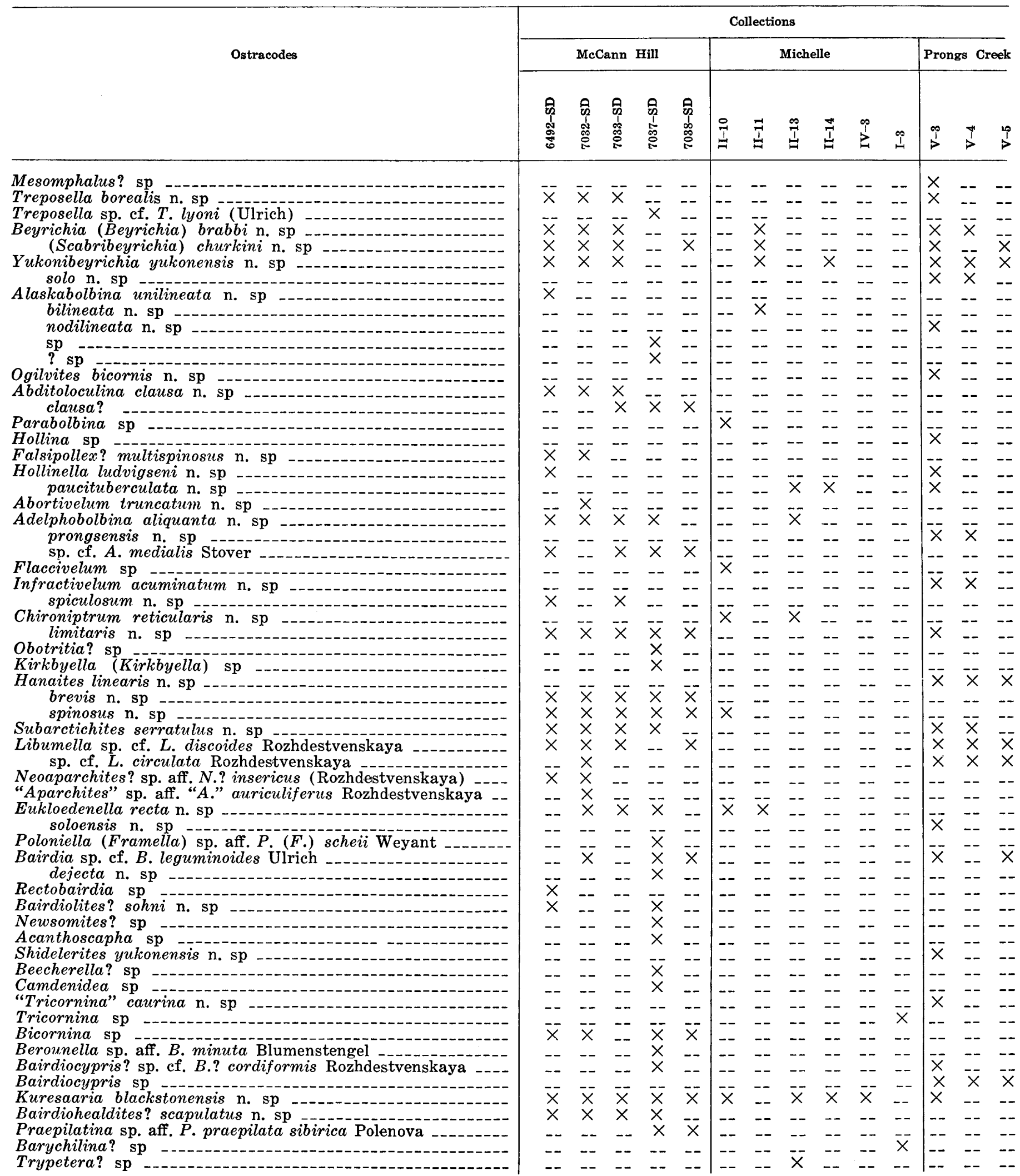


TABLE 1.-Ostracode taxa described in this paper and the formations and collections in which they occur-Continued

\begin{tabular}{|c|c|c|c|c|c|c|c|c|c|c|c|c|c|c|}
\hline \multirow{3}{*}{ Ostracodes } & \multicolumn{14}{|c|}{ Collections } \\
\hline & \multicolumn{5}{|c|}{ McCann Hill } & \multicolumn{6}{|c|}{ Michelle } & \multicolumn{3}{|c|}{ Prongs Creek } \\
\hline & 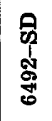 & 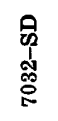 & 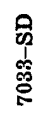 & $\begin{array}{l}0 \\
0 \\
0 \\
\frac{1}{0} \\
0\end{array}$ & $\begin{array}{l}\text { 요 } \\
0 \\
0 \\
0 \\
0\end{array}$ & 章 & $\overrightarrow{\vec{I}}$ & $\stackrel{\oplus}{\Xi}$ & $\stackrel{\vec{I}}{\stackrel{\Xi}{\mid}}$ & $\stackrel{p}{p}$ & $\stackrel{\infty}{\sim}$ & $\stackrel{p}{p}$ & $\vec{\prime}$ & $\stackrel{p}{>}$ \\
\hline Voronina sp. cf. $V$. inventa Rozhdestvenskaya & $x$ & $x$ & -- & -- & -- & -- & -- & -- & -- & -- & -- & -- & -- & -- \\
\hline Cavellina (Invisibila)? sp & -- & -- & -- & $x$ & -- & - & -- & -- & -- & -- & -- & -7 & -- & - \\
\hline Tubulibairdia sp Pachydomellid indet & $\frac{x}{x}$ & $\underset{x}{x}$ & $\times$ & $\underset{x}{X}$ & $\bar{x}$ & -- & -- & -- & -- & -- & -- & $x$ & -- & -- \\
\hline $\begin{array}{l}\text { Pacnydomenlid indet. } 1 \\
\text { Pachydomellid indet. } 2\end{array}$ & $\begin{array}{l}x \\
--\end{array}$ & x & -- & $\begin{array}{l}x \\
x\end{array}$ & $\begin{array}{c}x \\
--\end{array}$ & -- & -- & -- & -- & -- & -- & -- & -- & $\overline{-}$ \\
\hline Eriella? $\mathrm{sp}$ & -- & -- & -- & $\hat{x}$ & -- & -- & -- & -- & -- & -- & $\bar{x}$ & - & - & \\
\hline Neocraterellina? crescentifera n. sp & $\bar{x}$ & $\bar{x}$ & $\bar{x}$ & $\ddot{x}$ & -- & - & -- & - & -- & -- & -- & -- & - & \\
\hline Microcheilinella? sp & -- & -- & -- & -- & -- & -- & -- & -- & -- & -- & -- & $x$ & -- & \\
\hline Ostracode indet. $\mathbf{1}$ & -- & -- & -- & -- & -- & -- & -- & -- & -- & -- & $\times$ & -- & -- & \\
\hline Ostracode indet. 2 & $x$ & -- & -- & -- & -- & -- & -- & -- & -- & -- & -- & $-\overline{-}$ & -- & -- \\
\hline Ostracode indet. 3 & -- & -- & -- & -- & -- & -- & & -- & -- & -- & -- & $x$ & -- & -- \\
\hline
\end{tabular}

rare specimens occur in the McCann Hill Chert, 6 in the Michelle Formation, and 6 in the Prongs Creek Formation. Three of the single specimens from the Michelle Formation are from Ludvigsen collection I-3, which is shown by Ludvigsen (1972, fig. 3) as being more than 200 feet below the other ostracodebearing collections from the Michelle. Of the 22 significant taxa in the Prongs Creek, 13 also occur in the collections from the McCann Hill Chert, and of the 11 significant taxa in the Michelle, 8 also occur in the McCann Hill collections. The Michelle and Prongs Creek collections have five taxa in common. These figures include three species of beyrichiids which occur in all three formations. The ostracodes, as well as the other groups of fossils, therefore, suggest that at least part of the Michelle and Prongs Creek Formations and the limestone and shale member of the McCann Hill Chert are approximately the same age.

For purposes of intercontinental correlation the ostracodes are of little assistance in confirming the age of the Michelle and Prongs Creek Formations and of the limestone and shale member of the McCann Hill Chert as determined by other groups of fossils. This is partly because most of the species are new, but also because at least seven of the genera have not hitherto been reported from beds older than Middle Devonian (Eifelian), and six have not been reported from beds younger than middle Early Devonian (Siegenian). On a generic level, the most distinctive groups are the hollinaceans and the beyrichiaceans. The hollinacean genera Abditoloculina, Adelphobolbina, Falsipollex, Flaccivelum, Hollina, and Hollinella and the beyrichiacean Treposella would under other circumstances appear indicative of early Middle Devonian (Eifelian) age. All seven genera listed above occur with Eifelian conodonts (Huddle, oral commun., 1972) in collections from the Paraspirifer acuminatus Zone of the Jeffersonville Limestone at the Falls of the Ohio between Jeffersonville, Ind., and Louisville, $\mathrm{Ky}$. ; the hollinids have been described by Kesling and Peterson (1958). None of them has been found in upper Lower Devonian (Emsian) formations in eastern North America such as the Camden Chert (Bassler, 1941; Swain, 1953) or the Schoharie Formation (Berdan, 1971), nor have they been reported from formations of Emsian Age in the Rheinische Schiefergebirge (Groos and Jahnke, 1970; Stoltidis, 1971) or Ostthüringen (Zagora, 1968) in Germany, nor from Emsian formations in the Salair district of Siberia (Polenova, 1968).

Other Middle Devonian elements in the fauna are the forms closely related to Voronina inventa Rozhdestvenskaya, 1962, Neoaparchites? insericus (Rozhdestvenskaya, 1962), "Aparchites" auriculiferus Rozhdestvenskaya, 1962, Libumella discoides Rozhdestvenskaya, 1959, and Bairdiocypris? cordiformis Rozhdestvenskaya, 1959, all from beds considered to be Eifelian in Bashkiria, on the western slope of the Ural Mountains in the U.S.S.R.

On the other hand, Early Devonian or older elements of the fauna are represented by such genera as Mesomphalus, Beyrichia (Beyrichia), Beyrichia (Scabribeyrichia), Parabolbina, Newsomites, and Shidelerites. Beyrichia (Scabribeyrichia) and Shidelerites have not previously been reported from strata younger than Silurian; the other genera range from the Silurian into the early or middle Early Devonian (Gedinnian or Siegenian) but have 
not yet been reported from beds of Emsian Age. A form related to Praepilatina praepilata sibirica Polenova, 1970, from the upper Krekov beds in the Salair district of Siberia also suggests a Siegenian Age. The only Emsian element in the ostracode assemblage is the form closely related to Poloniella (Framella) scheii Weyant, 1968, from the lower part of the Blue Fiord Formation on Ellesmere Island, as this part of the formation is considered late Emsian by Boucot, Johnson, and Talent (1969, pl. 20).

Although the ostracodes from Alaska and Yukon Territory show little affinity with any described Emsian ostracode fauna, late Early Devonian ostracodes have been relatively little studied in comparison with those from the Middle Devonian of the North American midcontinent region, Germany, Czechoslovakia, Poland, and Russia. Because the collections from which the ostracodes were obtained have been dated as Emsian on the basis of other groups of fossils, it is necessary to extend downward the ranges of at least seven genera not previously known below the Middle Devonian. The evidence from conodonts and dacryoconarid tentaculites that the McCann Hill collections are late Emsian and the Michelle and Prongs Creek collections are early Emsian suggests that many of the ostracodes described here have an undifferentiated Emsian range. This ostracode assemblage appears to represent a provincial fauna combining relict beyrichiaceans with ancestral hollinaceans and including elements that appeared later in widely separated areas. It will probably prove useful for Emsian correlation within the Arctic province.

\section{LIST OF LOCALITIES}

1. McCann Hill Chert, lower limestone and shale member. USGS collection 6492-SD, one-half mile west of Hillard Peak, 3.4 miles N. $41^{\circ} \mathrm{W}$. of International Boundary Commission monument 105, $64^{\circ} 57^{\prime} 3^{\prime \prime}$ N., $141^{\circ} 04^{\prime} 5^{\prime \prime}$ W., about 140 feet above base of McCann Hill Chert. USGS collection 7032$\mathrm{SD}$, same locality as above but about 10 feet stratigraphically higher. USGS collection 7033-SD, same locality as above, composite sample from float material. USGS collection 7037-SD, from thin beds of limestone conglomerate in shale sequence, 300 feet east of USGS collection 6492-SD, $64^{\circ} 57^{\prime} 2^{\prime \prime}$ N., $141^{\circ} 4^{\prime} 9^{\prime \prime}$ W. USGS collection 7038$\mathrm{SD}$, same locality as above, 5 feet above USGS collection 7037-SD. All collections from Eagle (D-1) quadrangle, Alaska, made by E. E. Brabb, 1961, 1963.

2. Michelle Formation. GSC locality 86588, Lud- vigsen's sections II and III (fig. 2), east side of Blackstone River, $65^{\circ} 41.5^{\prime}$ N., $137^{\circ} 26.5^{\prime}$ W., Yukon Territory. Collections made by Rolf Ludvigsen.

II-10; 260 feet below top of Michelle Formation. II-11; 200 feet below top of Michelle Formation. II-13; 160 feet below top of Michelle Formation. II-14; 100 feet below top of Michelle Formation.

3. Michelle Formation. GSC locality 86589 , Ludvigsen's section IV (fig. 2), south-facing ridge approximately halfway between Hart and Blackstone Rivers, $65^{\circ} 41^{\prime}$ N., $137^{\circ} 01^{\prime}$ W., Yukon Territory. Collections made by Rolf Ludvigsen.

IV $-3 ; 125$ feet below top of Michelle Formation. 4. Michelle Formation. GSC locality 86587 , Ludvigsen's section I (fig. 2), west side of Hart River, $65^{\circ} 38.2^{\prime}$ N., $136^{\circ} 44^{\prime}$ W., Yukon Territory. Collections made by Rolf Ludvigsen.

I-3; about 75 feet above base of Michelle Formation.

5. Prongs Creek Formation. GSC locality 86590 , Ludvigsen's section V (fig. 2), Solo Creek, $65^{\circ} 51.4^{\prime}$ N., $134^{\circ} 15.5^{\prime}$ W., Yukon Territory. Collections made by Rolf Ludvigsen.

$\mathrm{V}-3 ; 161$ feet above Monograptus yukonensis.

$\mathrm{V}-4 ; 196$ feet above $M$. yukonensis.

$\mathrm{V}-5 ; 305$ feet above $M$. yukonensis.

\section{SYSTEMATIC PALEONTOLOGY}

Suprageneric classification of the Class Ostracoda is based largely on the "Treatise on Invertebrate Paleontology-Part Q, Arthropoda 3," edited by Moore (1961), except for the family Beyrichiidae, which is classified according to Martinsson (1962), and the superfamily Hollinacea, which is adopted from Bless and Jordan (1971). The terms used for morphologic features are based partly on the "Treatise," except for the terminology used for the beyrichiids, which follows that proposed by Martinsson (1962) and Henningsmoen (1965). Because this terminology is widely used by students of beyrichiids it seems desirable to use it here rather than to adhere to that of the "Treatise" (1961) for the sake of consistency.

All measurements of specimens were made with a micrometer ocular.

Abbreviations used for institutions from which collection or specimen numbers are cited are as follows: Geological Survey of Canada, GSC ; U.S. Geological Survey, USGS; U.S. National Museum of Natural History, USNM. The section and collection numbers of Ludvigsen (1970) have been used to facilitate comparison with later papers by Fåhraeus (1971) and Ludvigsen (1972). 


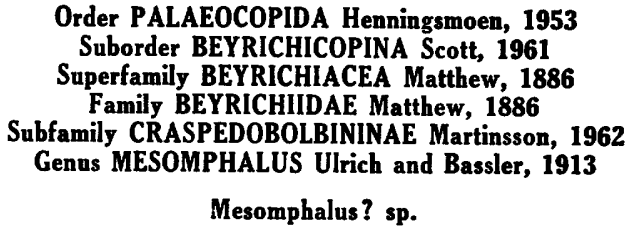

Plate 1, figures 1,2

?Mesomphalus sp., Copeland in Ludvigsen, 1970, p. 426, 427.

Description.-Valves apparently subquadrate in lateral view; hinge straight. Anterior cardinal angle about $105^{\circ}$. Anterior margin smoothly rounded; venter straight; posterior margin unknown. Greatest height and length unknown.

Valve surface papillose, papillae of uniform size. Trilobate, anterior lobe weakly developed, extending feebly to dorsum, separated from preadductorial node by a very low prenodal sulcus; preadductorial node situated above midvalve and separated from syllobium by narrow, shallow, posteriorly convex adductorial sulcus. Syllobium unknown. Ventral part of valve dissected by obliquely curved longitudinal fissus extending from beneath preadductorial node posteriorly for unknown distance. Prominent velar ridge separated from domicilium by pronounced groove paralieling free margin; velar ridge separated from incomplete marginal ridge by narrow groove. Marginal ridge composed anteriorly and posteriorly of short denticles or spines, none ventrally.

Material.-Two incomplete tecnomorphic valves.

Measurements.-Length of figured specimen GSC 29438, $1.8 \mathrm{~mm}$; height of figured specimen GSC 29439, $1.25 \mathrm{~mm}$.

Types.-Figured specimens, GSC 29438, 29439.

Discussion.-These specimens appear somewhat similar to Mesomphalus hartleyi Ulrich and Bassler, 1913 , as figured by Kesling and Rogers (1957, pl. 130, figs. 11-15). The marginal spines of the present specimens are more acuminate, and the preadductorial node apparently is in a more dorsal position. Without complete tecnomorphic and, more important, complete heteromorphic valves these specimens cannot be placed unequivocally within Mesomphalus. Martinsson (1962, p. 188-190) has indicated the similarity of the Devonian genus Mesomphalus to the Silurian genus Clintiella Martinsson, 1962. From the literature it appears, however, that differences exist between these genera based on velar and marginal structures. Cruminal differentiation is unknown.

Occurrence.-Ludvigsen collection V-3, Prongs Creek Formation, Solo Creek, Yukon Territory.
Subfamily TREPOSELLINAE Henningsmoen, 1954 Genus TREPOSELLA Ulrich and Bassler, 1908

Treposella borealis $n$. sp.

Plate 1, figures 5-10

Treposella sp., Berdan in Churkin and Brabb, 1968, table 1, pl. 4, figs. 16, 17. [Imprint 1967.]; Copeland in Ludvigsen, 1970 , p. 426.

Description.-Lateral outline amplete to preplete. Preadductorial lobe outlined by shallow indistinct prenodal sulcus; adductorial sulcus deep, narrow, widest at ventral end. Syllobium cuspate; cusp protrudes above hinge line. Fissus on syllobium connects with prenodal sulcus to form groove concentric to free margin. Velar ridge distinct, extends completely around free margin. Surface reticulate except for velar ridge and adductorial sulcus. Crumina ventral, elongate ovate, very finely punctate. Velar edge crosses crumina with two treposelline bridges; interior of crumina with strut about middle of length.

Material.-Fourteen specimens from Alaska, one specimen from Yukon.

Measurements.-The holotype, a heteromorphic valve, measures $2.35 \mathrm{~mm}$ in length and $1.50 \mathrm{~mm}$ in height. A paratype tecnomorphic valve measures $2.25 \mathrm{~mm}$ in length and $1.43 \mathrm{~mm}$ in height.

Types.-Holotype, USNM 170352; paratypes, USNM 170351, 173730, 173731, GSC 29453.

Discussion.-Treposella borealis differs from $T$. lyoni (Ulrich, 1891), the type species of Treposella, in having a less prominently cuspate syllobium and in having a punctate rather than striate crumina. It differs from $T$. stellata Kesling, 1955, in having only one fissus across the syllobium and no crista on the crumina. The morphology of the ventral surface of the crumina of $T$. borealis resembles that of Garniella Martinsson, 1962, as illustrated by Martinsson (1962, text fig. 89B). The dolonoid scar of Treposella lyoni, described by Martinsson (1962, p. 211-214) from the illustrations of Kesling and Rogers (1957, pl. 127, fig. 3), has not been observed on our specimens of $T$. borealis.

Occurrence.-USGS collections 6492-SD, 7032SD, 7033-SD, from the McCann Hill Chert, Eagle (D-1) quadrangle, Alaska; Ludvigsen collection V-3, from the Prongs Creek Formation, Solo Creek, Yukon Territory.

\section{Treposella sp. cf. T. Iyoni (Ulrich, 1891)}

Plate 1, figures 3, 4

Discussion.-Two small tecnomorphic specimens with the lobation of Treposella lyoni (Ulrich, 1891) and coarser reticulation than $T$. borealis $n$. sp. have been found in the McCann Hill Chert. These specimens have the cuspate, vertically divided syllobium 
of $T$. lyoni but differ from that species in having a very reduced velar ridge. Because the only two specimens found are probably immature individuals, an unequivocal specific assignment is not possible.

Measurements.-The figured specimen (pl. 1, fig. 3) is $0.75 \mathrm{~mm}$ long and $0.45 \mathrm{~mm}$ high.

Types.-Figured specimens, USNM 173728, 173729.

Occurrence.-USGS collection 7037-SD from the McCann Hill Chert, Eagle (D-1) quadrangle, Alaska.

\section{Subfamily BEYRICHIINAE Matthew, 1886 Genus BEYRICHIA M'Coy, 1846 Subgenus BEYRICHIA M'Coy, 1946 \\ Beyrichia (Beyrichia) brabbi n. sp. \\ Plate 2, figures 1-8}

Beyrichia (Beyrichia) sp. A, Berdan in Churkin and Brabb, 1968, table 1, pl. 4, figs. 11, 12. [Imprint 1967.]; Copeland in Ludvigsen, 1970, p. 426, 427.

Description.-Lateral outline preplete to amplete. Anterior lobe broad; prenodal sulcus distinct, inclined posteriorly and tending to isolate pyriform preadductorial lobe. Adductorial sulcus deep, curved anteriorly, extending half or more than half height of valve. Syllobium broad, undivided. Anterior cusp developed as spine; two posterodorsal spinose cusps on syllobium, widely separated, diverging at angle of about $40^{\circ}$. Velar ridge distinct, spinose. Surface covered with spines or pustules except for sulci and small field dorsal to adductorial sulcus, preadductorial lobe, and prenodal sulcus, in which are only two small spines, one dorsal to adductorial sulcus and one dorsal to preadductorial lobe. Finely granulose ornamentation superimposed on pustulose ornamentation. Crumina of heteromorph large, ovate, anteroventral, distinctly set off from domicilium, bounded posteriorly by adductorial sulcus. Ornamentation of crumina like that of domicilium except that pustules are smaller on ventral surface. Trace of velar ridge across ventral surface of crumina indicated by row of small pustules or spines.

Material.-More than 40 specimens from the McCann Hill Chert, more than 3 specimens from the Michelle Formation, and more than 6 specimens from the Prongs Creek Formation.

Measurements.-The holotype, a heteromorphic right valve, measures $2.6 \mathrm{~mm}$ in length and $1.5 \mathrm{~mm}$ in height. A tecnomorphic right valve, a paratype, measures $2.5 \mathrm{~mm}$ in length and $1.5 \mathrm{~mm}$ in height. Measurements of 27 specimens from the McCann Hill Chert (USGS colln. 6492-SD) are shown in figure 3.

Types.-Holotype, USNM 170346; paratypes, USNM 170347, 173732, 173733, 173734, 173735,
173736, GSC 29473, 29474.

Discussion.-This species is similar to Beyrichia (Beyrichia) arctigena Martinsson, 1960 in its undivided syllobium, the size and position of the crumina, and the presence of the two small spines above the adductorial sulcus and preadductorial lobe. However, unlike Beyrichia (Beyrichia) brabbi, B. (B.) arctigena is only very sparsely pustulose. In addition, the syllobial cusps of $B$. (B.) arctigena are closer together than those of $B$. (B.) brabbi. Both species differ from all other species assigned to Beyrichia in having undivided syllobia (Martinsson, 1960, p. 17). The species is named for Earl E. Brabb of the U.S. Geological Survey, who collected the first specimens.

Occurrence.-USGS collections 6492-SD, 7032SD, 7033-SD from the McCann Hill Chert, Eagle (D-1) quadrangle, Alaska; Ludvigsen collection II-11 from the Michelle Formation, Blackstone River, Yukon Territory; Ludvigsen collections V-3 and V-4, from the Prongs Creek Formation, Solo Creek, Yukon Territory.

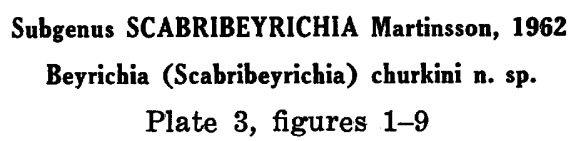

Beyrichia (Beyrichia) sp. B, Berdan in Churkin and Brabb, 1968, table 1, pl. 4, figs. 13, 14. [Imprint 1967.]; Copeland in Ludvigsen, 1970, p. 426, 427.

Description.-Lateral outline preplete to amplete. Anterior lobe broad; prenodal sulcus narrow, distinct, curved posteriorly beneath preadductorial lobe. Preadductorial lobe subpyriform, slanted posteriorly; adductorial sulcus wide, extending about half height of valve. Syllobium wide, divided by sinuate curving fissus or syllobial groove which joins prenodal sulcus beneath adductorial sulcus and preadductorial lobe at angle of approximately $90^{\circ}$. Velar ridge narrow, spinose. Anterior lobe cuspate; two closely spaced spinose cusps on syllobium. Entire surface except for sulci covered with closely spaced, prominent tubercles, four of which tend to merge to form calcarine spine. Crumina large, ovate, anteroventral, pustulose. Tubercles on ventral surface of crumina not markedly different from those on domicilium except for row of small tubercles marking trace of velar ridge.

Material.-More than 60 specimens from the McCann Hill Chert; more than 15 specimens from the Michelle Formation; more than 30 specimens from the Prongs Creek Formation.

Measurements.-The holotype, a heteromorphic left valve, is $2.80 \mathrm{~mm}$ long and $1.55 \mathrm{~mm}$ high. A paratype tecnomorphic left valve is $2.60 \mathrm{~mm}$ long 


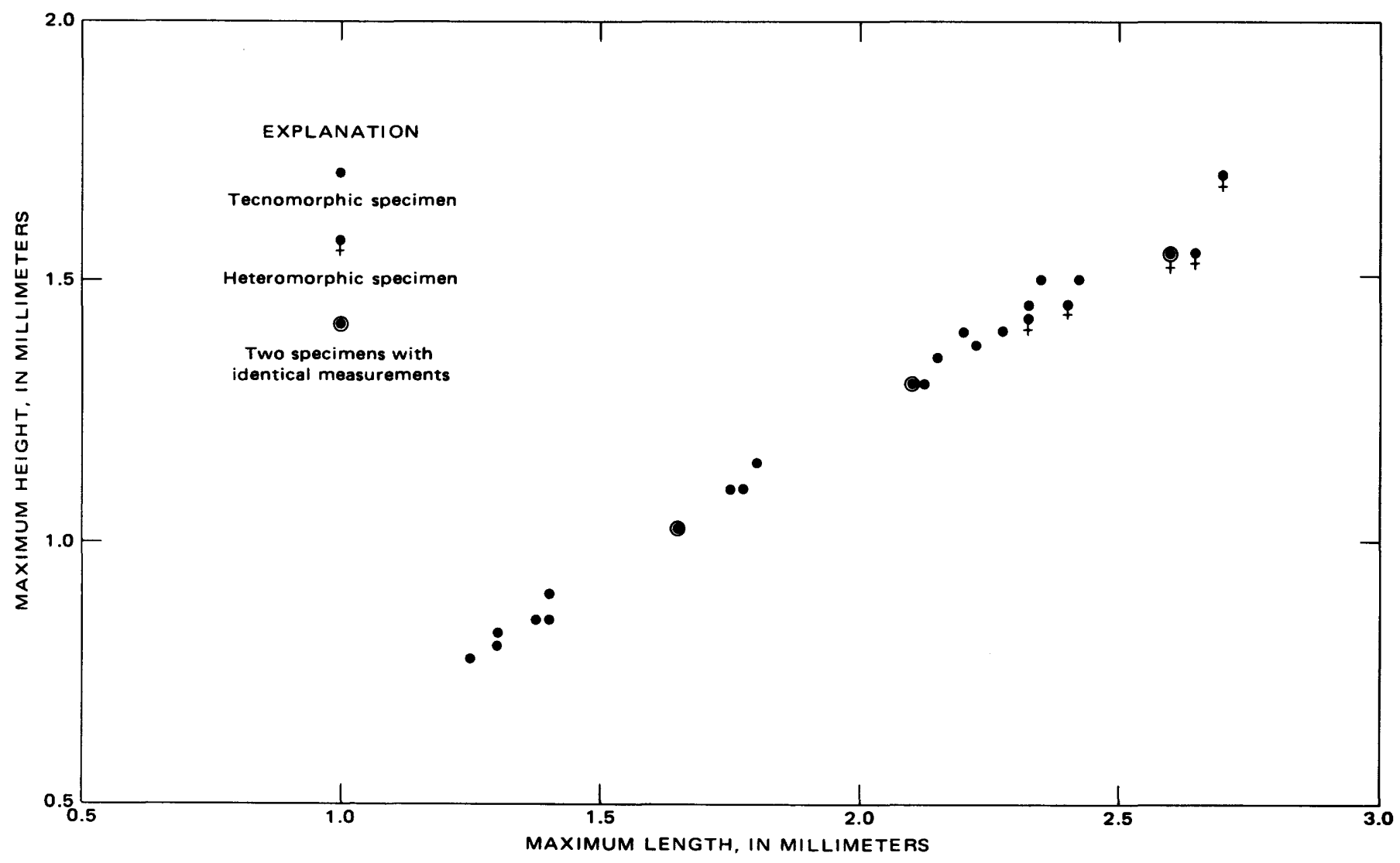

FIGURE 3.-Scatter diagram of maximum length versus maximum height for Beyrichia (Beyrichia) brabbi n. sp.; 27 specimens from the McCann Hill Chert (USGS colln. 6492-SD, paratype slide USNM 173735).

and $1.55 \mathrm{~mm}$ high. Measurements of 57 specimens from the McCann Hill Chert are shown in figure 4.

Types.-Holotype, USNM 170349; paratypes, USNM 170348, 173737, 173738, 173739, GSC 29469, 29470, 29471, 29472.

Discussion.-This species is here placed in the subgenus Scabribeyrichia Martinsson, 1962, because of the characteristic zygal arch outlined by the junction of the fissus or syllobial groove with the prenodal sulcus. Although it superficially resembles species of Eobeyrichia Henningsmoen, 1954, as illustrated by Henningsmoen (1954, p. 21, pl. 1), Eobeyrichia has a fissus on the anterior lobe as well as on the syllobium. Beyrichia (Scabribeyrichia) churkini resembles the form described by Martinsson (1962, p. 301-302, fig. 165B, 165C) as Beyrichia (aff. Scabribeyrichia) sp., from the Wenlock of Gotland, but the North American species has a narrower, more distinct fissus and sharper cusps. It differs from other described species of Scabribeyrichia, such as Beyrichia (Scabribeyrichia) foliosa (Jones, 1888), in being more pustulose. This species is named for Michael Churkin, Jr., who has collected and studied the McCann Hill Chert fauna.
Occurrence.-USGS collections 6492-SD, 7032SD, 7033-SD, 7038-SD, from the McCann Hill Chert, Eagle (D-1) quadrangle, Alaska; Ludvigsen collection II-11, Michelle Formation, Blackstone River, Yukon Territory; Ludvigsen collections V-3, V-5, Prongs Creek Formation, Solo Creek, Yukon Territory.

\section{Genus YUKONIBEYRICHIA n. gen.}

Type species.-Yukonibeyrichia yukonensis n. sp. Species included.-Yukonibeyrichia solo n. sp.

Diagnosis.-Beyrichiine ostracodes with wide, flattened anterior supravelar field sharply set off from remainder of domicilium. Prenodal sulcus weak to obsolete so that anterior lobe and preadductorial lobe tend to merge. Adductorial sulcus wide and deep. Syllobium with single cusp, with or without fissus. Crumina of heteromorph inflates and obliterates anterior supravelar field and occupies anteroventral part of domicilium up to prenodal sulcus. Ornamentation pustulose.

Discussion.-The lobation of this distinctive genus superficially resembles that of a hollinid rather than a beyrichiid, but the cruminal dimorph- 


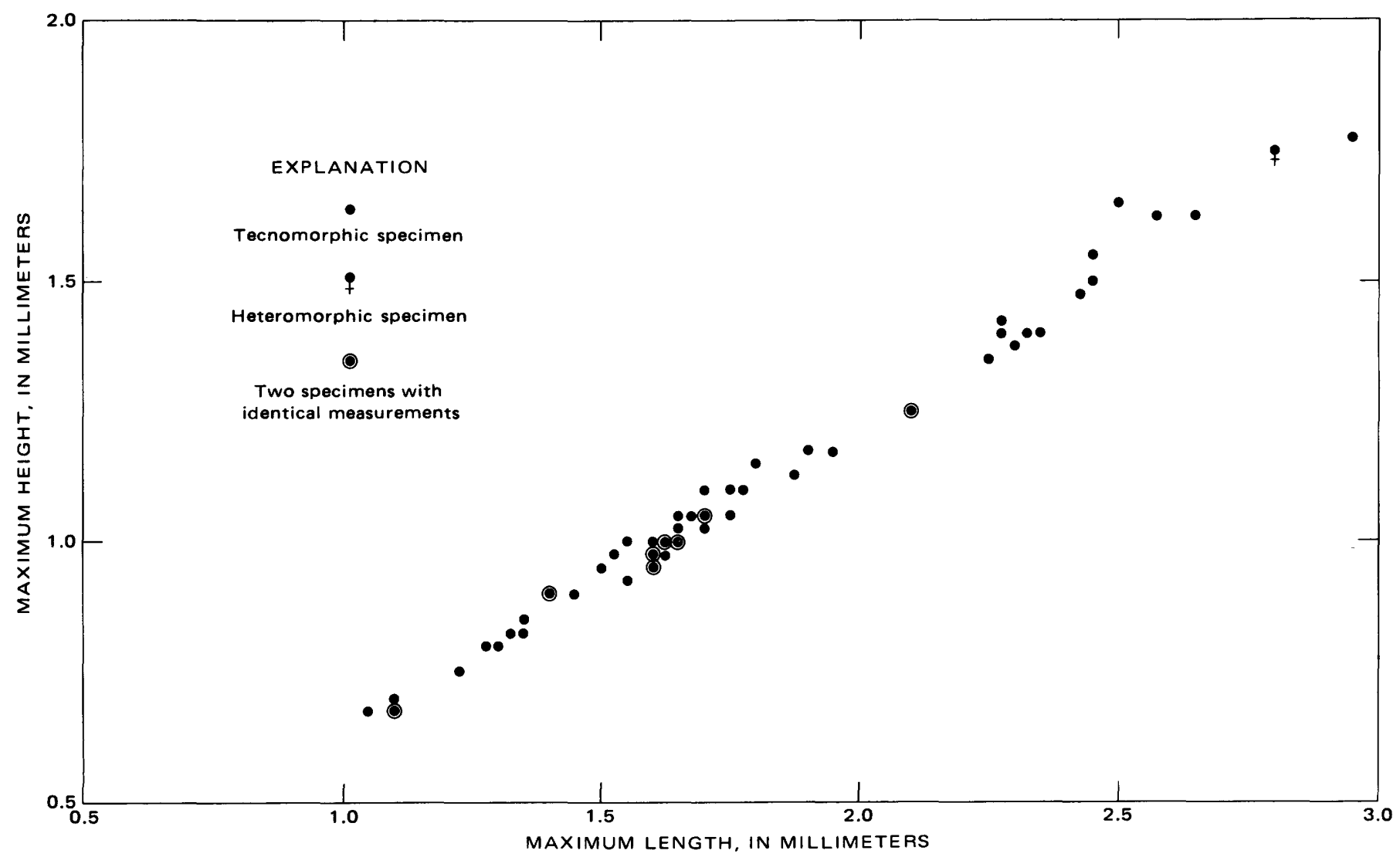

FIGURE 4.-Scatter diagram of maximum length versus maximum height for Beyrichia (Scabribeyrichia) churkini n. sp.; 57 specimens from the MeCann Hill Chert (USGS coll. 6492-SD, paratype slide USNM 173739).

ism indicates that it belongs with the latter group. It is apparently a late development of the line of Beyrichia s. s. The generic name is derived from Yukon Territory and the Yukon River area where it is found.

Geologic range.-As yet this genus is known only from the Lower Devonian of Alaska and Yukon Territory.

\footnotetext{
Yukonibeyrichia yukonensis n. sp.

Plate 4, figures 5-11
}

Beyrichiid, n. gen., n. sp., Berdan in Churkin and Brabb, 1968, pl. 4, fig. 10. [Imprint 1967.]

Description.-Lateral outline preplete; dorsal margin straight; anterior cardinal angle distinct; anterior margin curved smoothly into gently curved ventral margin; posterior margin gently curved; posterior cardinal angle more acute than anterior angle. Wide supravelar field extends anterodorsally around anterior lobe and preadductorial lobe to adductorial sulcus. Prenodal sulcus weak; preadductorial lobe pyriform, only slightly separated from small arcuate anterior lobe. Adductorial sulcus wide and deep. Syllobium large, with shallow fissus. Anterior cardinal angle cuspate; anterodorsal cusp on supravelar field dorsal to prenodal sulcus. Dorsal tubercle on cusp on syllobium; uncular tubercle on posterior supravelar field below posterior cardinal angle. Small tubercle near dorsum above adductorial sulcus. Supravelar field granulose to weakly papillose; remainder of domicilium strongly pustulose except for sulci and fissus. Crumina pustulose like domicilium. Velar ridge apparently crosses ventral surface of crumina without deflection.

Material.-Twenty-three valves from the McCann Hill Chert; more than three specimens from the Michelle Formation; more than 20 specimens from the Prongs Creek Formation.

Measurements.-The holotype, a large tecnomorphic left valve, is $2.80 \mathrm{~mm}$ long and $1.60 \mathrm{~mm}$ high. Another tecnomorphic left valve (USNM 173742) from the McCann Hill Chert is $2.60 \mathrm{~mm}$ long and $1.35 \mathrm{~mm}$ high. Measurements of 20 specimens from the McCann Hill Chert are shown in figure 5.

Types.-Holotype, GSC 29432, paratypes, GSC 29433,29434 , USNM 170345, 173740, 173741, 173742, 173743, 173744.

Discussion.-This species is characterized by its pustulose surface and prominent anterodorsal cusp. 


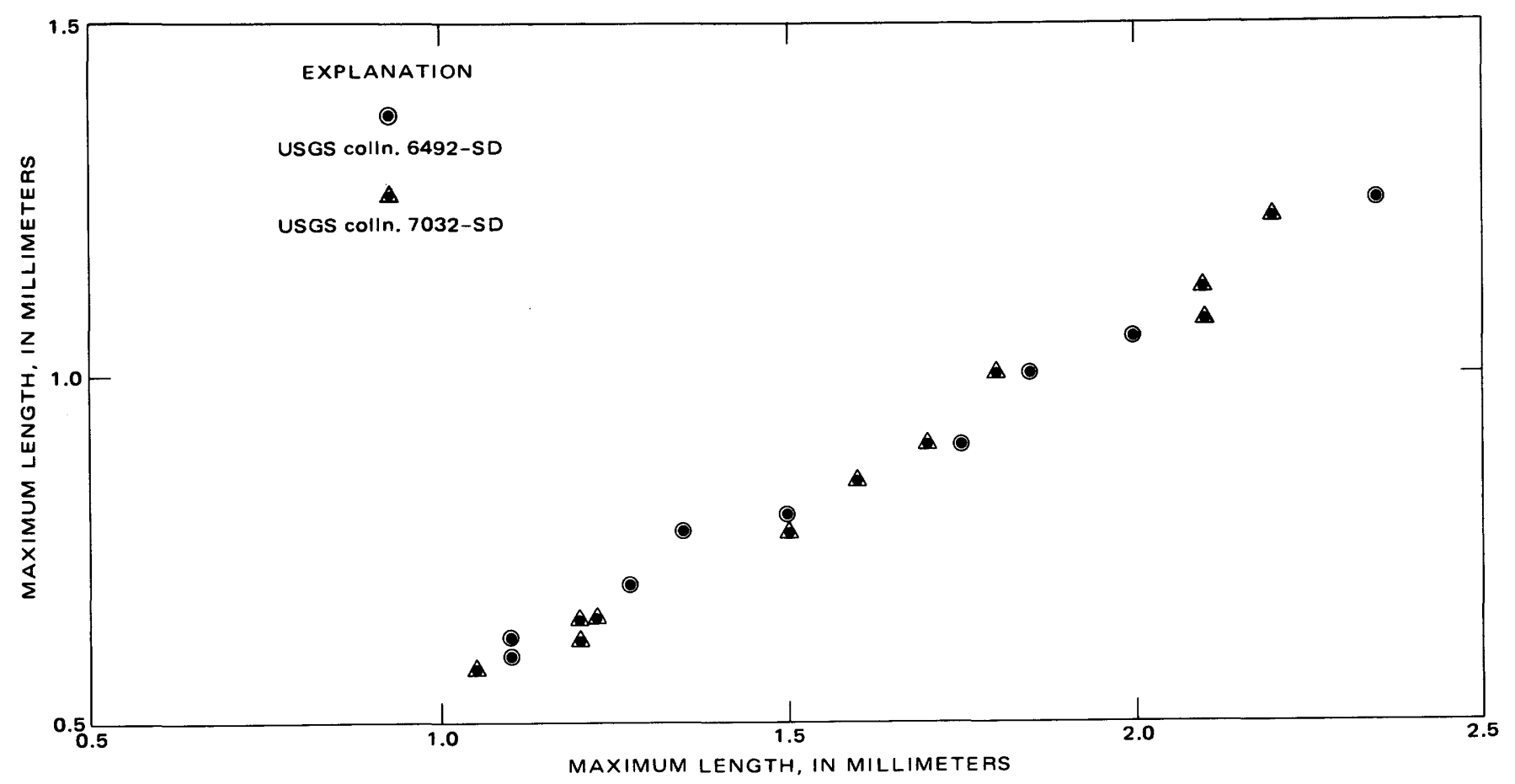

FIGURE 5.-Scatter diagram of maximum length versus maximum height for Yukonibeyrichia yukonensis n. sp.; 20 specimens from the McCann Hill Chert (USGS colln. 6492-SD, paratype slide USNM 173743; USGS colln. 7032-SD, paratype slide USNM 173744).

The uncular tubercle is also characteristic, although there is some variation in its relative size. The position of the uncular and other tubercles appears to be constant throughout the ontogeny of the species, but it is more prominent on immature specimens and better developed on specimens from the McCann Hill Chert than on specimens from the Prongs Creek Formation. The name of the species is based on its occurrence in the Yukon River Valley and Yukon Territory.

Occurrence.-USGS collections 6492-SD, 7032SD, 7033-SD, from the McCann Hill Chert, Eagle (D-1) quadrangle, Alaska; Ludvigsen collections II-11, II-14, from the Michelle Formation, Blackstone River, Yukon Territory ; Ludvigsen collections $\mathrm{V}-3, \mathrm{~V}-4, \mathrm{~V}-5$, from the Prongs Creek Formation, Solo Creek, Yukon Territory.

\section{Yukonibeyrichia solo n. sp.}

Plate 4, figures 1-4

Description.-Lateral outline preplete; anterior cardinal angle distinct. Anterior margin curved smoothly into gently curved ventral margin; posterior margin smoothly curved. Supravelar field wide anterodorsally, extends dorsally around end of anterior and preadductorial lobes to adductorial sulcus. No cusps or prominent tubercles on supravelar field.
Prenodal sulcus obsolete, so that anterior and preadductorial lobes are fused. Adductorial sulcus wide and deep. Syllobium lacking fissus; syllobium has one blunt cusp which lacks prominent tubercle. Surface of domicilium with low pustules except for supravelar field, which is granulose. Crumina pustulose like domicilium; velar ridge appears to cross ventral surface of crumina as slightly sinuous line. Antrum or groove between velar ridge and marginal ridge partly constricted beneath crumina.

Material.-Three specimens from the Prongs Creek Formation.

Measurements.-The holotype, a tecnomorphic right valve, is $2.30 \mathrm{~mm}$ long and $1.30 \mathrm{~mm}$ high. Paratype GSC 29436, a carapace, is $2.20 \mathrm{~mm}$ long and $1.30 \mathrm{~mm}$ high.

Types.-Holotype, GSC 29435; paratypes, GSC 29436, 29437.

Discussion.-Yukonibeyrichia solo differs from $Y$. yukonensis in the complete obsolescence of the prenodal sulcus, the lack of a fissus on the syllobium, and especially in the lack of the anterodorsal cusp, the uncular tubercle, and the tubercle above the adductorial sulcus. Although only three specimens have been found, the consistent character of the cusps and tubercles in several instars of $Y$. yukonensis suggests that the specimens lacking the anterodorsal 
cusp belong to a distinct and different species. The name of the species is derived from Solo Creek, Yukon Territory.

Occurrence.-Ludvigsen collections V-3 and V-4, Prongs Creek Formation, Solo Creek, Yukon Territory.

\section{Subfamily indet.}

Genus ALASKABOLBINA n. gen.

Type species.-Alaskabolbina unilineata n. sp.

Species included.-Alaskabolbina bilineata n. sp., Alaskabolbina nodilineata $\mathrm{n}$. sp.

Diagnosis.-Nonsulcate paleocope ostracodes with central bulb or node and with anterodorsal and posterodorsal cusps or spines. Velum tubulous, incomplete, extending from anterior cardinal angle to posteroventral slope, ending in hollow spine. Domiciliar ornamentation pustulose. Ridge or ridges (torus?) on subvelar field parallel to free margin. Heteromorph not known.

Discussion.-The tubulous velum of Alaskabolbina suggests beyrichiid or eurychilinid affinities, but until heteromorphs are found, the systematic position and relationship of this genus cannot be determined. The conspicuous bulb, which occupies the position of the median sulcus in other ostracodes, is similar to that of the Late Ordovician chilobolbinid genus Cystomatochilina Jaanusson, 1957, but Alaskabolbina lacks any trace of a median pit, and the velum does not extend around the entire free margin. Alaskabolbina may be related to the nonsulcate craspedobolbinine genera Apatobolbina Ulrich and Bassler, 1923, Leptobolbina Martinsson, 1962, and Schohariella Berdan, 1971, but these genera lack the median bulb. The name of the genus is derived from its occurrence in Alaska combined with -bolbina, in reference to the characteristic median swelling.

Geologic range.-As yet this genus is known only from the Lower Devonian of Alaska and Yukon Territory.

Alaskabolbina unilineata n. sp.

Plate 5, figures 13-15

Description.-Lateral outline amplete to slightly preplete. Large subcircular median node above midheight of valve. Median node verrucose, subconical in profile. Massive blunt verrucose anterodorsal and posterodorsal cusps protrude above hinge line. Surface finely papillose, with scattered tubercles arranged concentrically around median node; one large tubercle above node and between two dorsal cusps. Striated velum extending from anterodorsal angle to posterior part of free margin, ending in upward recurved spur. Velum curved away from contact margin in ventral view; subvelar field crossed by single finely denticulate toric ridge parallel to free margin. Heteromorph not known.

Material.-One right valve, and a few fragments from the McCann Hill Chert.

Measurements.-The holotype and only specimen is $1.70 \mathrm{~mm}$ long and $0.90 \mathrm{~mm}$ high.

Types.-Holotype, USNM 173745.

Discussion.-Although only one relatively complete specimen of this species has as yet been found, it is so distinctive that a specific name seems justified. It differs from other species of Alaskabolbina in having heavier dorsal cusps, a single toric ridge, and in being more sparsely papillose.

Occurrence.-USGS collection 6492-SD from the McCann Hill Chert, Eagle (D-1) quadrangle, Alaska.

\section{Alaskabolbina bilineata n. sp.}

Plate 5, figures 16-21

Description. - Lateral outline amplete. Valve nonsulcate, with large subcircular median node at or slightly above center of valve. Domicilium cuspate at both ends; cusps spinose, extending above dorsal margin. Surface papillose, with scattered tubercles surrounding central node and distributed over valve surface. Striated velum extending from anterodorsal angle (?) to posterior part of free margin, ending in tubulous spur. In ventral view, velum bowed outward near midvalve, in contact anteriorly and posteriorly with double torus; toric ridges parallel to and at some distance from marginal ridge.

Material.-Five specimens from the Michelle Formation.

Measurements.-The holotype is $1.80 \mathrm{~mm}$ long and $1.00 \mathrm{~mm}$ high.

Types.-Holotype, GSC 29464; paratypes, GSC 28465, 29466, 29467, 29468.

Discussion.-This species differs from Alaskabolbina unilineata, the type species, in having spinose rather than nodose dorsal cusps, more tubercles on the surface of the valve and double subvelar toric ridges rather than a single denticulate torus.

Occurrence.-Ludvigsen collection II-11, from the Michelle Formation, Blackstone River, Yukon Territory.

\section{Alaskabolbina nodilineata n. sp.}

Plate 5, figures 1-6

Description.-Lateral outline amplete. Valves nonsulcate, with large subcircular median node above center of valve. Valves with wide anterior extralo- 
bate area. Valves with larger tubercles in position of cusps, extending above dorsal margin. Surface papillose with numerous scattered tubercles surrounding and encroaching on median node, extra-lobate area with few tubercles. Striated velum extending from midanterior to posterior part of free margin, ending in spur. In ventral view, velum bowed outward near midvalve, with subvelar area convex and traversed by double row of tubercles (torus?) parallel with free margin. Interior with deep impressions of central node and anteroventral lobe reminiscent of crumina.

Material.-Two specimens from Prongs Creek Formation.

Measurements.-The holotype is $1.20 \mathrm{~mm}$ long and $0.60 \mathrm{~mm}$ high.

Types.-Holotype, GSC 29512; paratype, GSC 29513.

Discussion.-This species differs from Alaskabol bina unilineata in having a large anterior extralobate area, in being more pustulose, and in having a double row of subvelar tubercles as a toric structure in the position of the single denticulate torus of A. unilineata. It differs from A. bilineata in having a large anterior extralobate area, in being more pustulose, and in having a double row of subvelar tubercles instead of a double ridge as in A. bilineata.

The two valves which represent this species may be heteromorphic, but this is not certain. The ventral obesity of the specimens in lateral view, the convex nature of the subvelar field and the depth of the ventral lobate area in interior view suggest this possibility. However, they are not heteromorphs of either Alaskabolbina unilineata or A. bilineata because of the differences in the character of the ornamentation.

Occurrence.-Ludvigsen collection V-3 from the Prongs Creek Formation, Solo Creek, Yukon Territory.

\section{Alaskabolbina sp. \\ Plate 5, figures 11, 12}

Discussion.-Two small specimens (USNM 173844,173845 ) from the McCann Hill Chert (USGS colln. 7037-SD) are apparently immature tecnomorphs of a species of Alaskabolbina. They have the prominent dorsal cusps and median bulb characteristic of the genus, but the velum of both specimens is relatively short and the torus is poorly developed, making it impossible to assign them to any of the described species. The flaring velum of the larger specimen (USNM 173845, pl. 5, fig. 12) is like that of $A$. nodilineata $\mathrm{n}$. sp., but the dorsal cusps are not as well developed in that species. The smaller specimen is $0.55 \mathrm{~mm}$ long and $0.30 \mathrm{~mm}$ high; the larger specimen is $0.80 \mathrm{~mm}$ long and $0.40 \mathrm{~mm}$ high.

\section{Alaskabolbina? sp. \\ Plate 5, figures 7-10}

Discussion.-Four small specimens which appear to be related to Alaskabolbina have been found in the McCann Hill Chert (USGS colln. 7037-SD). These have the median bulb of Alaskabolbina, but lack dorsal cusps and are less papillose than any of the species here assigned to the genus. Two of the figured specimens, USNM 173840 (pl. 5, fig. 7) and USNM 173841 (pl. 5, fig. 8), have short vela which are bent almost perpendicularly to the plane of commissure; one, USNM 173842 (pl. 5, fig. 9), which is otherwise similar, has a longer and less recurved velum. The fourth figured specimen, USNM 173843 (pl. 5, fig. 10 ), has a short but not recurved velum and is more papillose than the others. These specimens are probably immature forms of two or more species of which the adults are as yet unknown. The material is not adequate for a formal description, but is illustrated here to show the variety of the ostracode fauna.

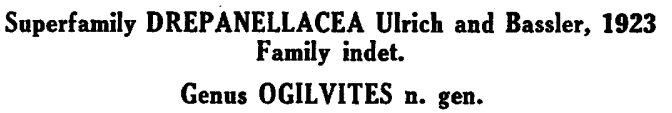

Type species.—Ogilvites bicornis n. sp.

Species included.-Knoxites argutula Zaspelova, 1959.

Diagnosis.-Small, straight-backed, bilobate drepanellids with prominent S2. Lobes coarsely reticulate; ventral part of valves with striae parallel to free margin and/or reticulae. Velar bend parallel to free margin ; free margin smooth.

Discussion.-The prominent, centrally located, nearly equal dorsal lobes of this genus distinguish it from other drepanellids. The position and types of ornamentation are likewise distinctive. The name of the genus is derived from the Ogilvie Mountains, eastern Yukon Territory, where it occurs.

Geologic range.-Lower Devonian, Yukon Territory; Upper Devonian (Frasnian), U.S.S.R.

Ogilvites bicornis n. sp.

Plate 6, figure 1

Description.-Valves subovate in lateral view, bilobate. Dorsum straight; free margins evenly rounded; cardinal angles curved. Left(?) valve slightly overlapping right(?) around free margin. 
Prominent S2 extends from dorsal margin to midvalve. Lobation consists of two conical tubercles, one on either side of S2, which extend well above hinge line. Tubercles reticulate with prominent ridges; about 10 meshlike polygons on each. Reticulae on tubercles limited ventrally by ridge extending beneath S2 and dying out at anterior and posterior edges of reticulation.

Ventral part of valve with five ridges paralleling free margin. Most dorsal ridge, mentioned above, limits tubercular reticulation; second ridge extends uninterruptedly to each cardinal angle; third ridge only as long as most dorsal ridge and branches medially into several reticulae; fourth ridge extends to each cardinal angle and branches near midvalve to form reticulae; fifth ridge borders entire margin of valve as velar bend; marginal area smooth.

Material.-One complete carapace from the Prongs Creek Formation.

Measurements.-The holotype carapace is $0.9 \mathrm{~mm}$ long. The height to the hinge line is $0.60 \mathrm{~mm}$; the height to the tip of the dorsal tubercles is $0.65 \mathrm{~mm}$.

Types.-Holotype, GSC 29454.

Discussion.-This species differs from Ogilvites argutula (Zaspelova, 1959) from post-Snezha beds in the Novgorod district, U.S.S.R., in having more prominent dorsal tubercles wth reticulae more uniform in size and distribution. Both species have a similar type of surface ornamentation (Zaspelova, 1959 , pl. 8 , figs. $7 \mathrm{a}, \mathrm{b}$ ), but $O$. argutula has a more prominent velar flange rather than a velar bend as in $O$. bicornis.

Occurrence.-Ludvigsen collection V-3, Prongs Creek Formation, Solo Creek, Yukon Territory.

Superfamily HOLLINACEA Swartz, 1936

Family CTENOLOCULINIDAE Jaanusson and Martinsson, 1956

Subfamily CTENOLOCULININAE Jaanusson and Martinsson, 1956

Genus ABDITOLOCULINA Kesling, 1952

Abditoloculina clausa n. sp.

Plate 6, figures 2-8

Abditoloculina sp., Berdan in Churkin and Brabb, 1968, table 1, pl. 4, fig. 3. [Imprint 1967.]

Description.-Lateral outline amplete to preplete. L1 projecting as cusp above hinge line; L2 rounded node below hinge line; L3 rounded node about same size as L2 but set higher on valve. S1 weak; S2 deep, narrow, confined to dorsal third of valve. Prominent median spurlike node beneath S2, below and between L2 and L3. Two posterior tubercles, one just ventral to posterior cardinal angle, second in posteroventral quarter of valve beneath first tubercle. Tecnomorph with anterior node at or slightly above midheight on anterior margin; velum extends from node postero- ventrally to posterior third of valve. Anteroventral spur above but merging with velum. Heteromorph with six loculi extending from anterior node to posterior third of valve; anteroventral spur on third loculus. Loculi closed in ventral view (pl. 6, fig. 4). Surface finely granulose.

Material.-Seven tecnomorphic and 3 heteromorphic carapaces, and more than 10 valves from the McCann Hill Chert.

Measurements.-The holotype, a heteromorphic carapace, is $0.90 \mathrm{~mm}$ long, $0.50 \mathrm{~mm}$ high, and 0.50 $\mathrm{mm}$ wide, including the spur. A tecnomorphic carapace (USNM 173746) is $0.90 \mathrm{~mm}$ long, $0.47 \mathrm{~mm}$ high, and $0.50 \mathrm{~mm}$ wide. There is little variation in size of individuals.

Types.-Holotype, USNM 170338; paratypes, USNM 173746, 173747, 173748, 173749.

Discussion.-Kesling and Peterson (1958, p. 130) concluded that species of Abditoloculina may be discriminated by the number of loculi present in the heteromorphs. A. clausa differs from the 14 previously described species of Abditoloculina in having only 6 loculi ; the lowest number previously recorded was 7 for the type species of the genus, $A$. insolita Kesling, 1952, and for $A$. binodata Kesling and Peterson, 1958. In addition, unlike any of the other species, the loculi of $A$. clausa are closed in ventral view (pl. 6, fig. 4) ; that is, in a complete carapace with the valves in contact, no locular openings can be seen. The adult tecnomorph of $A$. clausa differs from those of other species in having relatively subdued spurs and a well-developed velum. This species is similar to A. binodata in having two posterior tubercles. The name of the species is derived from the Latin clausus, $-a,-u m$, referring to the closed loculi.

Occurrence.-USGS collections 6492-SD, 7032$\mathrm{SD}$, and 7033-SD from the McCann Hill Chert, Eagle (D-1) quadrangle, Alaska.

\section{Abditoloculina clausa? \\ Plate 6, figure 9}

Description.-Lateral outline preplete. L1 projecting as cusp above hinge line; L2 rounded node below hinge line; L3 rounded node about same size as L2 but set higher on valve. S2 wide and deep. Prominent median spur beneath S2, below and between L2 and L3. Two posterior tubercles, one just below posterior cardinal angle, second in posteroventral quarter of valve beneath first tubercle. Anterior node at or slightly above midheight on anterior margin. Anteroventral posteriorly curved spur in anterior third of valve, on anteroventral margin. 
Material.-Three tecnomorphic right valves from the McCann Hill Chert.

Measurements.-The figured specimen is $0.70 \mathrm{~mm}$ long and $0.40 \mathrm{~mm}$ high.

Types.-Figured specimen, USNM 173750.

Discussion.-The lobation of these three valves resembles that of tecnomorphs of Abditoloculina clausa n. sp. except for the pronounced median and anteroventral spurs; they also differ in lacking a well-defined velum. The spurs are suggestive of $A$. binodata Kesling and Peterson, 1958, but the tecnomorph of $A$. binodata has not been described. They may possibly be immature tecnomorphs of $A$. clausa if the trimorphic concept (Bless and Jordan, 1971, 1972 ) is substantiated. However, this material is not adequate either to prove or disprove the trimorphic concept.

Occurrence.-USGS collections 7033-SD, 7037SD, and 7038-SD from the McCann Hill Chert, Eagle (D-1) quadrangle, Alaska.

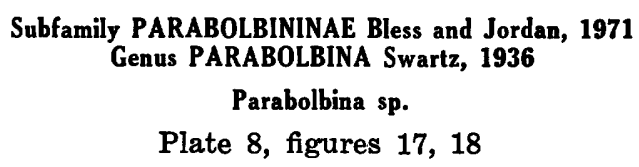

Plate 8, figures 17, 18

Description.-Carapace elongate, slightly preplete, trilobate. Dorsal border straight; anterior border subround; ventral border gently convex; posterior border tapering, subround. Anterior cardinal angle abrupt, more than $90^{\circ}$; posterior cardinal angle acuminate. All lobes confluent with ventral inflation. L1 low, nearly merged with small L2; L3 broad, occupying posterior half of valve, separated anteriorly from L2 by deep geniculate S2 extending from dorsum and ending abruptly near midvalve. Lateral surface ornamented with papillae of various sizes, free border smooth. Spurs located at anteroventral and posteroventral parts of valve, large, blunt, ends broken. Anterior spurs flattened and closer to free margin than posterior spurs.

Material.-One tecnomorphic carapace from the Michelle Formation.

Measurements.-The figured specimen is $0.93 \mathrm{~mm}$ long, $0.52 \mathrm{~mm}$ high, and $0.50 \mathrm{~mm}$ wide.

Types.-Figured specimen, GSC 29449.

Discussion.-This possibly immature specimen is somewhat similar to Parabolbina pulchella Kesling and McMillan, 1951, from the Bell Shale of Michigan, but lacks a tuberculate free border. $P$. hypercala Kesling and Tabor, 1953, from the Genshaw Formation of Michigan is more papillose and has L3 more pronounced. P. granosa (Ulrich, 1900), the type species of the genus, has smaller spurs and a less distinct L2.

Occurrence.-Ludvigsen collection II-10, from the Michelle Formation, Blackstone River, Yukon Territory.

\section{Family HOLLINIDAE Swartz, 1936 \\ Subfamily HOLLININAE Swartz, 1936 \\ Genus HOLLINA Ulrich and Bassler, 1908 Hollina sp. \\ Plate 6, figure 23}

Description. - Lateral outline amplete; hinge straight; cardinal angles obtuse. Free margins evenly rounded. L1 large, vertically elongate parallel to anterior border, terminating near middle of anteroventral part of valve; L2 is small node; L3 is large bulb; L4 narrow, vertically elongate, smaller than L1. S1 narrow, somewhat sinuous; S2 deep, particularly in dorsal half of valve, sinuous, dorsally confluent with S1, passing between L2 and L3 and between two ventral lobes; S3 deep, vertical. All sulci reach ventral border. Two large ventral lobes, anterior one nodelike, ventral of $\mathrm{L} 2$, posterior one elongate-triangular, knoblike, ventral of L3. Marginal tubercles on ridge or bend parallel with entire free margin; tubercles of ventral part larger. Entire surface covered with papillae, those on lobes being larger than those in sulci.

Material.-One tecnomorphic right valve.

Measurements.-The figured specimen is $1.50 \mathrm{~mm}$ long and $0.93 \mathrm{~mm}$ high.

Types.-Figured specimen, GSC 29441.

Discussion.-This specimen appears to represent a species which is similar to Hollina insolens (Ulrich, 1900) and $H$. pyxidata Kesling, 1953. Both of those species, however, have a different arrangement of the two ventral lobes, which project as spurs, and L1 and L4 are more nodelike and L2 is smaller. Also, H. pyxidata is more posteriorly acuminate. $H$. compressa Kesling and Peterson, 1958, has a flatter valve surface and elliptical spurs.

Occurrence.-Ludvigsen collection V-3, Prongs Creek Formation, Solo Creek, Yukon Territory.

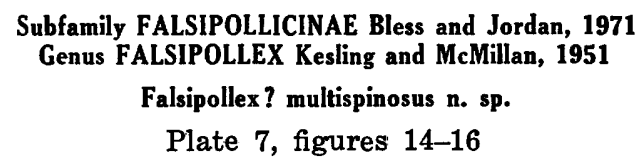

Description.-Lateral outline amplete. Hinge line straight; anterior margin curved; ventral margin less curved; posterior margin smoothly curved. L1 subdued, separated from L2 by short, shallow S1. L2 small, rounded; L3 bulbous, separated from ventral lobe by shallow groove. Velum in tecnomorph replaced by row of spines; velum in hetero- 
morph forms an anteroventral, elongate elliptical dolonal pouch. Surface covered with fairly long blunt spines except for sulci. Ornamentation between spines finely granular.

Material.-One heteromorphic right valve, one broken heteromorphic left valve, and one broken tecnomorphic left valve, all from the McCann Hill Chert.

Measurements.-The holotype is $1.80 \mathrm{~mm}$ long and $1.05 \mathrm{~mm}$ high.

Types.-Holotype, USNM 173761; paratypes, USNM 173762, 173763.

Discussion.-This species is only questionably assigned to Falsipollex because it apparently lacks the two ventral spurs on the tecnomorph which are considered diagnostic of the genus by Kesling and McMillan (1951, p. 67-68). However, the lobation, ornamentation and dolonate character of the heteromorphic velum are all more suggestive of Falsipollex than of any other hollinid genus. The specific name is derived from the abundant spines.

Occurrence.-USGS collections 6492-SD, 7032$\mathrm{SD}$, from the McCann Hill Chert, Eagle (D-1) quadrangle, Alaska.

\section{Family HOLLINELLIDAE Bless and Jordan, 1971}

Discussion.-Bless and Jordan (1971, p. 870-873, 880-881) proposed the family Hollinellidae for hollinomorph ostracodes with velar and lobate dimorphism. They considered the "tecnomorphs" of hollinellid genera to be those with a wide frill and welldeveloped antrum and the "heteromorphs" to be those with a narrow frill and a canaliculus, because in genera such as Jordanites Bless, 1967 and Hollinella (Praehollinella) Bless and Jordan, 1971, juvenile specimens have a wide frill (Bless and Jordan, 1971 , p. 870-872). Later, Bless and Jordan (1972, p. 10-13) substituted the terms "presumable male" and "presumable female" for "tecnomorph" and "heteromorph," respectively. As originally proposed by Jaanusson and Martinsson (1956, p. 401-402), the term "tecnomorph" referred to juveniles of both sexes and the adult dimorph which resembled the juveniles; "heteromorph" referred to the adult dimorph which differed from the juveniles. Because there is no evidence that the adult male, rather than the female, did not develop dimorphism in the last molt, we are using the terms "tecnomorph" and "heteromorph" rather than "presumable male" and "presumable female." Although Bless and Jordan (1971) considered the wide frilled forms with a relatively narrower L3 to be tecnomorphs in the Hollinellidae, the only hollinellid for which we have growth stages, Adelphobolbina aliquanta n. sp., has narrow frilled juveniles with a relatively wide L3. Pending further study of Early and Middle Devonian hollinellids, we are considering the tecnomorph to be the narrow frilled form in the following descriptions.

\section{Genus HOLLINELla Coryell, 1928 \\ Hollinella ludvigseni n. sp. \\ Plate 7, figures 1-3}

?Hollinella sp., Copeland in Ludvigsen, 1970, p. 426.

Description.-Valves subelliptical, preplete; hinge line long and straight. L1 broad, low; L2 small, ovate, nearly joined to L1; L3 bulbous, hemispherical, projecting to or slightly above hinge line. S1 short, shallow, indistinct; S2 deep, expanded ventrally below proximal parts of L2 and L3; a shallow groove present posterior to L3. Ventral lobe from L1-L2 to posterior part of valve. Surface ornamented with small, closely spaced papillae. Velar frill broad, papillose, extending from anterior cardinal angle to midposteroventral margin, with a posterior spinelike projection. Frill flat to slightly convex in tecnomorph, slightly concave in heteromorphic valves. Posteriorly, valves have marginal denticles.

Material.-Two specimens from the Prongs Creek Formation, one specimen from the McCann Hill Chert.

Measurements.-A heteromorphic valve is 1.20 $\mathrm{mm}$ long and $0.75 \mathrm{~mm}$ high; a tecnomorphic valve is $1.15 \mathrm{~mm}$ long and $0.70 \mathrm{~mm}$ high.

Types.-Holotype, GSC 29462; paratypes, GSC 29463, USNM 173764.

Discussion.-This species differs from Hollinella antespinosa (Ulrich, 1891) and $H$. plauta Kesling and Tabor, 1953, in having L3 hemispherical, without a dorsal projection. From $H$. pumila Kesling, 1953, and $H$. senticosa Kesling, 1953, it differs in having a much more pronounced frill in both dimorphs.

Occurrence.-Ludvigsen collection V-3, Prongs Creek Formation, Solo Creek, Yukon Territory; USGS collection 6492-SD, McCann Hill Chert, Eagle (D-1) quadrangle, Alaska.

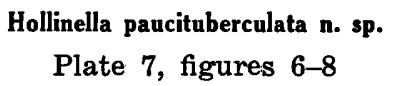

?Hollinella sp., Copeland in Ludvigsen, 1970, p. 426.

Description.-Valves triangular-subelliptical, preplete; hinge long, straight. L1 broad, with dorsal cusp projecting above hinge line on left valve; L2 elongate, joined ventrally to L1; L3 large, bulbous, hemispherical, projecting above hinge line. S1 short, shallow to threadlike; S2 deep, joined dorsally to S1, with smooth, shallow geniculate ventral extension 
crossing ventral lobe to velar frill; an indistinct smooth groove along posterior edge of L3. Ventral lobe traversed by ventral extension of S2 and postL3 groove. Lobes ornamented with widely spaced tubercles which are especially sparse on posterior quarter of valves. Velar frill flat, broad in heteromorph, narrower in tecnomorph, extending from anterior cardinal angle to midposteroventral margin, with posterior spinelike projection. Valves with marginal denticles posteriorly.

Material.-More than 20 valves from the Prongs Creek Formation and the Michelle Formation.

Measurements.-The average length of several specimens is $1.49 \mathrm{~mm}$; the average height is 0.87 $\mathrm{mm}$.

Types.-Holotype. GSC 29494; paratypes, GSC 29495, 29496.

Discussion.-The sparsely tuberculate lobes, the very sparsely tuberculate posterior, and the anterior cusp on the left valve serve to distinguish this species from the other species of Hollinella which have a ventral extension of S2. $H$. paucituberculata differs from $H$. antespinosa (Ulrich, 1891) in having a more distinct ventral extension of $\mathrm{S} 2$, different surface ornamentation, and a differently shaped L3. It is more similar to $H$. sella Stover, 1956, but as illustrated by Stover (1956, pl. 111, figs. 1-6), $H$. sella has a more distinct L2 and a more bulbous L3 than $H$. paucituberculata. Also, $H$. paucituberculata has a small, posteriorly directed spine at the posterior cardinal angle which may prove to be of specific importance. The presence of this spine, the anterodorsal cusp, and the pattern of the tubercles in this species are very similar to the same characters in Adelphobolbina aliquanta n. sp.

Occurrence.-Ludvigsen collections II-13, and II14, from the Michelle Formation, Blackstone River, Yukon Territory, and Ludvigsen collection V-3, from the Prongs Creek Formation, Solo Creek, Yukon Territory.

\section{Genus ABORTIVELUM n. gen.}

Type species.-Abortivelum truncatum n. sp.

Species included.-Only the type species.

Diagnosis.-Hollinellid ostracodes with cuspate L1, distinct L2, L3 large and confluent with ventral lobe. Velum reduced to velar bend or ridge in tecnomorph, restricted to anterior and anteroventral part of valves in heteromorph. Heteromorphic velum not distinctly set off from domicilium.

Discussion.-The reduced and suppressed velum distinguishes this genus from other hollinellid genera. Abortivelum most closely resembles Flaccivelum Kesling and Tabor, 1952, by the lack of dis- tinct separation between the heteromorphic velum and the domicilium, but in Flaccivelum the velum extends posteriorly beyond S2 and ends in a sharp spur, whereas in Abortivelum the velum does not extend posteriorly beyond S2 and merges smoothly with the surface of the valve. The name of the genus is based on the suppressed character of the velum.

Geologic range.-Lower Devonian of Alaska.

\section{Abortivelum truncatum n. sp.}

Plate 6, figures 10-16

Description.-Lateral outline preplete. Hinge line straight; anterior margin rounded; ventral margin smoothly curved and merging with smoothly curved posterior margin. L1 cuspate on both valves; cusp projecting above hinge line in lateral view. L2 small, oblong, distinctly separated from L1 by very short but deep S1. L3 large, bulbous, projecting above hinge line in lateral view; separated from posterior slope of valve by shallow posterodorsal depression but not clearly separated posteroventrally or ventrally. S2 deep, narrow, extending from dorsal margin to about midvalve. Tecnomorph with velar bend extending from anterior cardinal angle to posteroventral quarter of valve; heteromorph with velar frill extending from anterior cardinal angle to below S2. Velar frill merges with lateral surface of valve and is not distinctly separated from it. Surface finely granulose.

Material.-Nineteen specimens, including one complete heteromorphic and three complete tecnomorphic carapaces, from the McCann Hill Chert.

Measurements.-The holotype is $1.35 \mathrm{~mm}$ long and $0.85 \mathrm{~mm}$ high.

Types.-Holotype, USNM 173752; paratypes, USNM 173751, $173753,173754$.

Discussion.-This distinctive species does not closely resemble any previously described hollinellid. The specific name is derived from the truncated appearance of the heteromorph.

Occurrence.-USGS collection 7032-SD, from the McCann Hill Chert, Eagle (D-1) quadrangle, Alaska.

\section{Genus ADELPHOBOLBINA Stover, 1956 \\ Adelphobolbina aliquanta n. sp. \\ Plate 6, figures 17-22}

Adelphobolbina sp., Berdan in Churkin and Brabb, 1968, table 1, pl. 4, fig. 6. [Imprint 1967.]; Copeland in Ludvigsen, 1970, p. 426 (part).

Description.-Carapace elongate, amplete. Dorsum straight; anterior margin narrowly rounded; ventral margin smoothly curved; posterior margin denticulate, gently curved to acuminate posterior cardinal angle. L1 large, inflated, dorsally with tu- 
bercle projecting above hinge line, which is most prominent on left valve, posteriorly with shallow depression (S1) marking junction with fused L2. S2 deep, extending from dorsal border to midvalve, geniculate, concave anteriorly. L3 large, inflated, extending smoothly into ventral lobe, distinctly separated from posterodorsal field. Posterior surface of valve sloping gently to posterior margin. Cardinal angles distinct, anterior about $110^{\circ}$, posterior about $90^{\circ}$; some specimens with posterior cardinal spine.

Velar frill extending from anterior cardinal angle to posteroventral part of valve, terminating posteriorly in spine. Lateral surface with numerous tubercles on lobate areas; posterior surface with few tubercles. Smaller tubercles along dorsal margin and at outer edge of velar frill. Heteromorphic valves with wide straight velar frill; tecnomorphic frill narrower.

Material.-More than 40 specimens from the McCann Hill Chert; 1 specimen from the Michelle Formation.

Measurements.-The holotype is $1.55 \mathrm{~mm}$ long and $0.90 \mathrm{~mm}$ high. A smaller tecnomorph is $1.50 \mathrm{~mm}$ long and $0.85 \mathrm{~mm}$ high.

Types.-Holotype, USNM 173755; paratypes, USNM 170341, 173756, 173757, 173758, GSC 29497.

Discussion.-This species is similar to Adelphobolbina papillosa (Ulrich, 1891) but is less tuberculate on the posterior slope, has a velar frill ending abruptly rather than smoothly as in A. papillosa, has an anterodorsal cusp on the left valve, and is more acuminate posteriorly. A. aliquanta differs from $A$. megalia (Kesling and Tabor, 1953) and $A$. pinguis (Kesling and McMillan, 1951) in being more coarsely tuberculate, but it is not coarsely spinose like A. spicata (Kesling and McMillan, 1951). A. medialis Stover, 1956 and $A$. trilobata (Stewart, 1936) have a longer S2 than A. aliquanta. According to Warthin (1937, card 66), A. bulbosa (Tolmachoff, 1926), from the Middle Devonian (bed Db) of Ellesmere Island, is evenly pustulose, except on the velar frill, and A. papillata (Tolmachoff, 1926) is pustulose on the lobes but not on the posterior slope (Warthin, 1937, card 67). The specific name aliquanta refers to the moderate number of tubercles.

Occurrence._USGS collections 6492-SD, 7032SD, 7033-SD, 7037-SD, from the McCann Hill Chert, Eagle (D-1) quadrangle, Alaska; Ludvigsen collection II-13 from the Michelle Formation, Blackstone River, Yukon Territory.

\section{Adelphobolbina prongsensis n. sp.}

Plate 7, figures 9-13

Adelphobolbina sp., Copeland in Norris, 1967a, p. 138, 140; Copeland in Ludvigsen, 1970, p. 426 (part).
Description. - Carapace elongate, subelliptical, slightly preplete in lateral view. Dorsum straight; anterior margin rounded; ventral margin gently curved; posterior margin rounded. S2 deep, extending from dorsal border to midvalve, slightly concave anteriorly and continued as shallow narrow constriction nearly to ventral frill. L1 large, inflated, with shallow depression posteriorly marking junction with fused L2. L3 large, inflated, slightly constricted at confluence with gently curved ventral lobe. Posterior surface of valve sloping gently to posterior margin. Cardinal angles obtuse, anterior about $120^{\circ}$, posterior about $100^{\circ}$.

Velar frill extending from anterior cardinal angle to posteroventral part of valve, wider anteriorly. Lateral surface with papillae of two sizes; smaller papillae on lobes and larger ones on posterior part of valves and, on tecnomorphic valve, between velar frill and lobate areas. Heteromorphic valve with wide, straight velar frill almost in contact with ventral lobe; larger papillae restricted to posterior part of valve.

Material.-Five specimens from the Prongs Creek Formation.

Measurements.-The holotype is $1.45 \mathrm{~mm}$ long and $0.93 \mathrm{~mm}$ high. A tecnomorphic valve, paratype GSC 29501, is $1.45 \mathrm{~mm}$ long and $0.84 \mathrm{~mm}$ high.

Types.-Holotype, GSC 29498; paratypes, GSC 29499, 29500, 29501, 29502.

Discussion.-This species is most similar to Adelphobolbina papillosa (Ulrich, 1891), from the Jeffersonville Limestone of Indiana and $A$. megalia (Kesling and Tabor, 1953) from the Genshaw Formation of Michigan. A. papillosa, however, has more and larger papillae and, on the heteromorph, a more discrete, prominent velar frill (Kesling and Tabor, 1953, pl. 3, figs. 16, 17) ; A. megalia has a broader L3, more discrete velar frill, and apparently lacks the faint ventral constriction at the base of S2 which slightly separates L1 from the ventral lobe. This ventral constriction or prolongation of S2 is not as well developed as that in $A$. medialis Stover, 1956, where it is a definite part of S2. A. medialis, unlike $A$. prongsensis, is evenly papillose.

Occurrence.-Ludvigsen collections V-3, V-4, from the Prongs Creek Formation, Solo Creek, Yukon Territory.

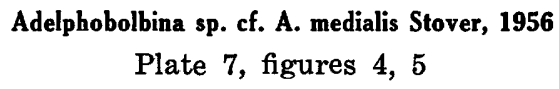

Adelphobolbina medialis Stover, 1956, p. 1104-1105, pl. 112, figs. 4-9.

Description.-Lateral outline amplete; dorsum straight; anterior and posterior margins evenly rounded; ventral margin smoothly curved. L1 large, 
low, separated from small oval L2 by short, shallow, indistinct S1. S2 wide, deep, extending more than half height of valve and continued ventrally to margin of domicilium by shallow depression. L3 large, inflated, merging with ventral lobe but distinctly separated from relatively narrow posterodorsal field. Cardinal angles obtuse. Velar frill extending from anterior cardinal angle to posterior edge of L3. Surface of domicilium evenly papillose except for deep parts of S2. A few scattered papillae present on velar frill.

Material.-Twenty valves from the McCann Hill Chert.

Measurements.-The two figured specimens are $1.25 \mathrm{~mm}$ long and $0.77 \mathrm{~mm}$ high and $1.25 \mathrm{~mm}$ long and $0.75 \mathrm{~mm}$ high, respectively.

Types.-Figured specimens, USNM 173759, 173760.

Discussion.-The specimens from the McCann Hill Chert all appear to be immature tecnomorphs. They resemble Adelphobolbina medialis Stover, 1956, in having S2 long and extending in a shallow furrow to the velar frill, in the evenly papillose surface and in the inflated L3. However, in typical A. medialis, L2 is completely merged with $\mathrm{L} 1$, and $\mathrm{S} 1$ is entirely suppressed. Also, A. medialis appears to lack papillae on the velar frill. A. medialis is from the Windom Member of the Moscow Shale (Middle Devonian) of western New York, and until definite adult specimens from the Lower Devonian of Alaska can be found it seems better to compare the McCann Hill Chert specimens with $A$. medialis rather than assigning them to the species.

Occurrence.-USGS collections 6492-SD, 7033SD, 7037-SD, 7038-SD, from the McCann Hill Chert, Eagle (D-1) quadrangle, Alaska.

\section{Genus FLACCIVELUM Kesling and Peterson, 1958 Flaccivelum sp.}

Plate 8, figures 15, 16

Description.-Valve elongate, amplete. L2 somewhat elongate, partly fused with L1; dorsal edge of L1 extending to hinge line. S2 deep, curved anteriorly, extending from hinge line to near midvalve. L3 broad, extending slightly above hinge line. L1 and L3 confluent with ventral lobe. Posterior part of valve gently convex, not lobate. Heteromorph with broad flat frill, confluent with lateral surface and deflected laterally at its posterior end.

Material.-One heteromorphic right valve from the Michelle Formation.

Measurements.-The figured specimen is $1.10 \mathrm{~mm}$ long and $0.70 \mathrm{~mm}$ high.

Types.-Figured specimen, GSC 29509.

Discussion.-This specimen is most nearly similar to Flaccivelum teleutaea (Kesling and Tabor, 1952) and $F$. informis (Ulrich, 1891), but differs from both in lacking a posteroventral projection of the ventral lobe and in having L3 confluent with the ventral lobe.

Occurrence.-Ludvigsen collection II-10, Michelle Formation, Blackstone River, Yukon Territory.

\section{Genus INFRACTIVELUM n. gen.}

Type species.-Infractivelum acuminatum n. sp. Species included.-Infractivelum spiculosum n. sp.

Diagnosis.-Hollinellid ostracodes with distinct L2 and prominent L3 continuous with ventral lobe. Velum continuous from anterior cardinal angle to midposteroventral slope in both tecnomorphs and heteromorphs. Heteromorphic velum only weakly separated from lateral surface of domicilium. Tecnomorphic velum of same extent as heteromorphic velum but narrow and flaring away from free margin. L1 may extend as cusp above hinge line on left valve of adult tecnomorph.

Discussion.-The lobation of Infractivelum differs from that of Hollinella Coryell, 1928, in having L3 confluent with the ventral lobe rather than bulbous, and from that of Adelphobolbina Stover, 1956, in having L3 narrower and more prominent. Infractivelum resembles Ruptivelum Kesling and Weiss, 1953 , in having a relatively distinct $\mathrm{L} 2$, but differs from that genus in having an uninterrupted tecnomorphic velum even in immature specimens (pl. 8, fig. 20). The heteromorphic velum of Infractivelum is like that of Flaccivelum Kesling and Tabor, 1952, but lacks the outward posterior swing of that genus, and the lobation of Infractivelum is more distinct. Jordanites Bless, 1967, and Hollinella (Praehollinella) Bless and Jordan, 1971, both have the velum merging gradually with the domicilium at its posterior end rather than truncated as in Infractivelum. The name is based on the unbroken character of the velum.

Geologic range.-Lower Devonian of Alaska and Yukon Territory.

\section{Infractivelum acuminatum $n$. sp. Plate 8, figures 19-23}

Adelphobolbina sp., Copeland in Ludvigsen, 1970, p. 426 (part).

Description. - Carapace elongate, subelliptical, preplete, somewhat acuminate posteriorly. Dorsum long, straight; lateral borders subround; free margins gently curved. S2 deep, slitlike, extending from dorsal margin to midvalve, slightly concave anteriorly. L1 large, inflated, with short dorsal cusp extending above hinge line of left valve. L2 fused to L1 ventrally but separated dorsally by short S1. L3 large, inflated, somewhat angular dorsally and extending to or beyond hinge line. Posterior surface of 
valve sloping gently to posterior margin. Anterior cardinal angle broad, about $110^{\circ}$; posterior cardinal angle narrow, nearly $90^{\circ}$. Velar frill extending from anterior corner to posteroventral part of valve, narrow in tecnomorphs. Heteromorphic valves with wider frill confluent with $\mathrm{L} 1$ and ventral lobe. Lateral surface with uniform fine papillae.

Material.-Five specimens from the Prongs Creek Formation.

Measurements.-The holotype is $1.60 \mathrm{~mm}$ long and $1.00 \mathrm{~mm}$ high. A tecnomorphic left valve is $1.30 \mathrm{~mm}$ long and $0.75 \mathrm{~mm}$ high.

Types.-Holotype, GSC 29503; paratypes, GSC 29504, 29505, 29506, 29507.

Discussion.-Small specimens which are considered to be immature tecnomorphs of this species do not have as acuminate an L3 as the adults.

Occurrence.-Ludvigsen collections $\mathrm{V}-3$ and $\mathrm{V}-4$, from the Prongs Creek Formation, Solo Creek, Yukon Territory.

\section{Infractivelum spiculosum n. sp.}

Plate 8, figures 24-27

Hollinella? sp., Berdan in Churkin and Brabb, 1968, table 1, pl. 4, fig. 7. [Imprint 1967.]

Description.-Lateral outline preplete; dorsal margin straight; anterior margin smoothly curved; ventral margin less sharply curved; posterior margin curved up to sharp posterior cardinal angle, which is about $90^{\circ}$. Anterior cardinal angle rounded. L1 with anterodorsal cusp which projects over hinge line on both valves; L2 small, ovate, separated from L1 by short shallow S1; L3 bulbous, acuminate, with point directed perpendicular to lateral surface. S2 wide, deep to about midheight of valve, curved anteriorly beneath L2 and extended as shallow groove around anterior end of ventral lobe to velar frill. Posterior part of valve slopes smoothly to posterior margin. Surface finely granulose with scattered large papillae on the lobate areas, especially prominent on L3 and parallel to velar frill. Velar frill extends from anterior cardinal angle to posteroventral part of valves; wide, confluent with lateral surface, and curved toward contact margin in heteromorph; narrower and reflexed away from contact margin in tecnomorph.

Material.-Six specimens from the McCann Hill Chert.

Measurements.-The holotype is $1.55 \mathrm{~mm}$ long and $0.92 \mathrm{~mm}$ high. A tecnomorphic paratype is $1.30 \mathrm{~mm}$ long and $0.77 \mathrm{~mm}$ high.

Types.-Holotype, USNM 107342; paratypes, USNM 173765, 173766, 173767, 173768.

Discussion. - Infractivelum spiculosum differs from I. acuminatum in having a more acuminate L3, distinct anterodorsal cusps on both valves and larger, and less regularly distributed papillae. The specific name refers to the sharp, anterodorsal cusps.

Occurrence. - USGS collections 6492-SD and 7033-SD, from the McCann Hill Chert, Eagle (D-1) quadrangle, Alaska.

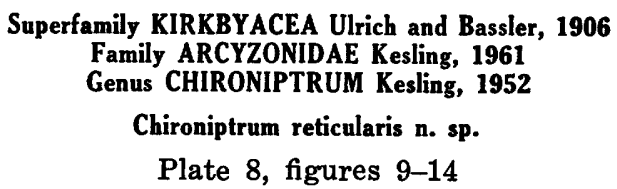

Chironiptrum sp., Copeland in Ludvigsen, 1970, p. 426, 427 (part).

Description.-Valves subelliptical, slightly postplete; right larger than left. Hinge line straight; free margins evenly curved. Deep pit near center of valve. Lateral surface surrounded by wide flaring frill confluent with dorsal ridge. Greatest height and width posterior. Lateral surface strongly reticulate; frill and channel smooth. Marginal ridge on both valves; ridge on right valve larger, somewhat tuberculate. Thin ridge at contact margin of right valve for closure against marginal ridge of left valve. Marginal ridge extending posteriorly beyond frill in some specimens.

Material.-Six specimens from the Michelle Formation.

Measurements.-Average of several specimens, length, $0.80 \mathrm{~mm}$, height, $0.50-0.55 \mathrm{~mm}$.

Types.-Holotype, GSC 29456; paratypes, GSC 29457, 29458, 29459, 29460, 29461.

Discussion.-This species is typical of the genus, but differs from Chironiptrum oiostathmicum Kesling, 1952, the type species, in being more coarsely reticulate, in lacking papillae at the intersections of the reticulae, and in lacking spurlike projections at the cardinal angles.

Occurrence.-Ludvigsen collections II-10 and II13 from the Michelle Formation, Blackstone Creek, Yukon Territory.

\section{Chironiptrum limitaris n. sp. \\ Plate 8, figures 2-8}

Chironiptrum sp., Berdan in Churkin and Brabb, 1968, table 1, pl. 4, fig. 2. [Imprint 1967.]; Copeland in Ludvigsen, 1970 , p. 426, 427 (part).

Description._-Valves subelliptical, slightly postplete; hinge line straight; anterior and posterior margins evenly curved; ventral margin gently curved to nearly straight. Deep drop-shaped pit slightly anterior of center of valve. Lateral surface surrounded by wide flaring frill confluent with dorsal ridge, which is only faintly visible along dorsal margin in lateral view. Lateral surface finely reticulate, some papillae at junctions of ridges forming reticulation. 
Frill and channel smooth. Marginal ridge around free margin.

Material.-More than 60 specimens from the McCann Hill Chert, 1 specimen from the Prongs Creek Formation.

Measurements.-The holotype is $0.80 \mathrm{~mm}$ long, $0.50 \mathrm{~mm}$ high, and $0.40 \mathrm{~mm}$ wide. Measurements of 53 other specimens are shown in figure 6 .

Types.-Holotypes, USNM 173770; paratypes, GSC 29455, USNM 170337, 173769, 173771, 173772, 173773.

Discussion.-This species is most similar to Chironiptrum oiostathmicum Kesling, 1952, in shape, size of reticulation, and presence of papillae on the lateral surface, but the reduction of the frill along the dorsal margin in $C$. limitaris distinguishes it from that species. C. limitaris differs from C. reticularis $\mathrm{n}$. sp. in the presence of papillae on the lateral surface of the valve and in being more finely reticulate.

This species is fairly abundant in collection from the McCann Hill Chert, but only one collection, USGS collection 7037-SD, contains many immature specimens; the other collections contain mostly adults.

Occurrence.-USGS collections 6492-SD, 7032SD, 7033-SD, 7037-SD, 7038-SD, all from the McCann Hill Chert, Eagle (D-1) quadrangle, Alaska;
Ludvigsen collection V-3, Prongs Creek Formation, Solo Creek, Yukon Territory.

\section{Genus OBOTRITIA Adamczak, 1968 \\ Obotritia? sp. \\ Plate 8 , figure 1}

Description.-Lateral outline amplete to slightly preplete; hinge line straight; free margins evenly rounded. Subelliptical high carina approximately concentric about obscure muscle spot but eccentric to margins of valve; low dorsally, slightly sinuate anterodorsally, high and flaring anteroventrally, ventrally, and posteriorly. Posterior quarter of valve extends beyond carina. Anterior cardinal angle produced as anterodorsal spine; posterior cardinal angle broken. Lateral surface enclosed by carina very finely punctate; surface outside carina smooth.

Material.-One left valve from the McCann Hill Chert.

Measurements.-The figured specimen is $0.70 \mathrm{~mm}$ long and $0.47 \mathrm{~mm}$ high.

Types.-Figured specimen, USNM 173774.

Discussion.-This single specimen is questionably assigned to Obotritia Adamczak, 1968, because it has a muscle spot rather than a central pit and an elliptical carina which is confluent with the dorsal ridge. However, Obotritia eifeliensis Adamczak, 1968, as described and illustrated by Adamczak (1968, p. 85-

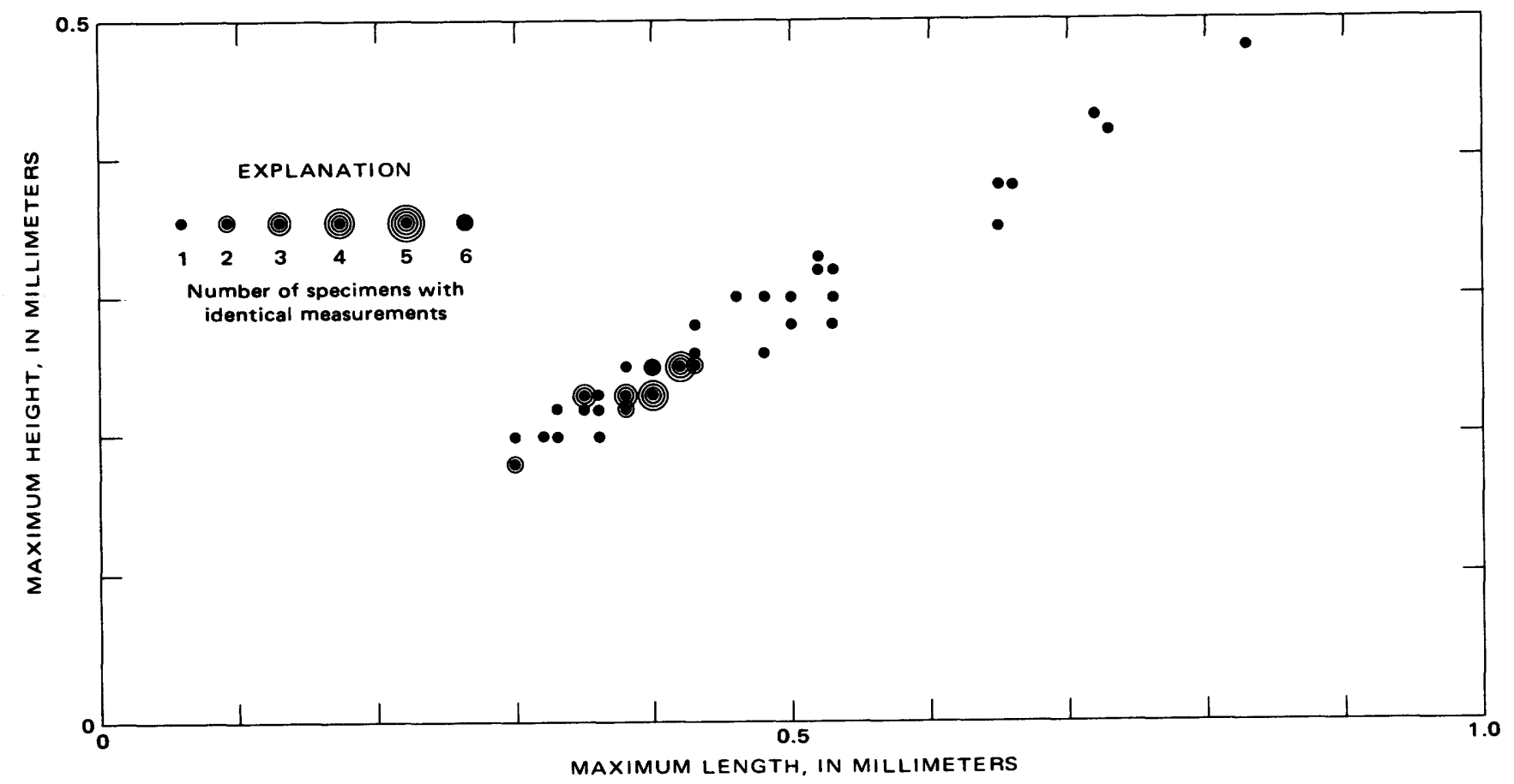

FIgURE 6.-Scatter diagram of maximum length versus maximum height for Chironiptrum limitaris $\mathrm{n}$. sp.; 53 specimens from the McCann Hill Chert (USGS colln. 7037-SD, paratype slide USNM 173772). 
86 , pl. 38, figs. 1-3) is coarsely reticulated and the carina is parallel to the free margins.

Occurrence.-USGS collection 7037-SD, from the McCann Hill Chert, Eagle (D-1) quadrangle, Alaska.

\section{Family KIRKBYELLIDAE Sohn, 1961 \\ Genus KIRKBYELLA Coryell and Booth, 1933 \\ Subgenus KIRKBYELLA Coryell and Booth, 1933 \\ Kirkbyella (Kirkbyella) sp. \\ Plate 9, figure 1}

Description.-Lateral outline amplete; anterior and posterior margins smoothly curved; ventral margin straight. Essentially unisulcate; S1 obsolete, S2 narrow, deep, extending from hinge line to onehalf or one-third height of valve and curving dorsally and ventrally to outline small rounded L2. Ventral lobe large, massive, projecting as sharp spine posteriorly, separated from ventral margin by narrow rim. Cardinal angles obtuse. Valve covered with very fine striations approximately parallel to margins.

Material.-Three valves from the McCann Hill Chert.

Measurements.-The figured specimen is $0.60 \mathrm{~mm}$ long and $0.30 \mathrm{~mm}$ high.

Types.-Figured specimen, USNM 173775.

Discussion.-These specimens have the narrow rim beneath the posterior part of the ventral lobe characteristic of Kirkbyella (Kirkbyella) as described by Sohn (1961, p. 143) and are consequently assigned to that subgenus. The specimens are not sufficiently complete to justify giving them a formal name, but the distinctive striated ornamentation is unlike that of any other described species of Kirkbyella.

Occurrence.-USGS collection 7037-SD from the McCann Hill Chert, Eagle (D-1) quadrangle, Alaska.

\section{Suborder NODELLOCOPINA Becker, 1968 \\ Superfamily NODELLACEA Becker, 1968 \\ Family NODELLIDAE Zaspelova, 1952 \\ Genus HANAITES Pokorný, 1950}

Type species.-Halliella (Hanaites) givetiana Pokorný, 1950.

Species included.-Proplectrum platum Kesling and McMillan, 1951.

?Eurychilina mirabilis Polenova, 1952.

Hanaites linearis $\mathrm{n}$. sp.

Hanaites brevis $\mathrm{n}$. sp.

Hanaites spinosus n. sp.

Revised diagnosis.-Unisulcate paleocope ostracodes, preplete to amplete in lateral outline. Sulcus vertical or slanted posteriorly. Velum developed an- teriorly as palmate or hooklike projection (hamus) in tecnomorph; heteromorph with velum widened and bent away from free margin anteriorly. Lateral surface reticulate or punctate; velum and sulcus smooth.

Discussion.-Hanaites, originally considered a subgenus of Halliella by Pokorny (1950, p. 599), was placed in the Hollinidae by Stover $(1956$, p. 1105) because the velar dimorphism of the heteromorphs which he had found suggested a relationship with the hollinids. Recently Becker (1968a, p. 129-131; 1968b, p. 553-555) proposed the suborder Nodellocopina and the superfamily Nodellacea to include the family Nodellidae Zaspelova, 1952, with two genera, Nodella Zaspelova, 1952, and Tetracornella Zaspelova, 1952, which have hamal dimorphism, that is, velar dimorphism in which the tecnomorphic velum forms a projection or hook (hamus) anteriorly and the heteromorphic velum widens and flares away from the contact margin anteriorly. This type of dimorphism is also characteristic of Hanaites, which accordingly is here assigned to the family Nodellidae.

Geologic range.-Lower Devonian of Alaska and Yukon Territory; Middle Devonian of the eastcentral United States, Czechoslovakia, and possibly the U.S.S.R.

\section{Hanaites linearis n. sp.}

Plate 9, figures 2, 3

Description.-Carapace elongate; lateral outline preplete. Hinge line straight; anterior border evenly curved; ventral border straight to convex, inclined; posterior border more acutely convex, somewhat acuminate. Anterior cardinal angle about $100^{\circ}$; posterior cardinal angle $75^{\circ}$ to $80^{\circ}$. Sulcation consisting of $\mathrm{S} 2$, which slants slightly posteriorly from dorsal margin to slightly below midvalve. S2 widens and deepens ventrally, ending in rounded pit, and is bounded, except dorsally, by smooth rim. Lobation consisting of confluent L1 and L2, ventral lobe and L3.

Velar frill continuous from posterodorsal corner to midanterior margin, in heteromorph becoming broader anteriorly, in tecnomorph of equal width throughout and terminating anteriorly in a spurlike process (hamus). Smooth antrum between velar frill and fine marginal ridge. Marginal ridge projects slightly beyond velar frill posteroventrally.

Surface of valves deeply reticulate, except for S2 and anterodorsal corner, with row of reticulae at dorsal contact of velar frill and domicilium. Dorsal crest limits reticulae dorsally, extending as fine ridge from near anterior end of velar frill, above L1-L2, forming part of rim around S2, projecting across L3 as a straight ridge posteriorly from the postero- 
dorsal corner of S2 and ending in a downcurved, more broadly projecting angulation.

Material.-Four specimens from the Prongs Creek Formation.

Measurements.-The holotype is $1.38 \mathrm{~mm}$ long and $0.65 \mathrm{~mm}$ high.

Types.-Holotype, GSC 29478; paratype, GSC 29477.

Discussion.-This species differs from Hanaites givetiana Pokorný, 1950, the type species of the genus, in the development of a dorsal crest and in having S2 inclined posteriorly rather than vertical (Pokorný, 1950, p. 600.) H. platus (Kesling and McMillan, 1951) lacks the dorsal crest of $H$. linearis, has a more pronounced palmate anterior spur and a posterodorsal node. Eurychilina mirabilis Polenova, 1952, appears to be referable to Hanaites, but the illustrations of this species (Polenova, 1952, pl. 1, fig. 5; Rozhdestvenskaya, 1962, pl. 6, figs. 1, 2) indicate that it has a spine at the posterior cardinal angle and that its $\mathrm{S2}$ is more vertical than that of $H$. linearis. Differences between $H$. linearis and the two new species, $H$. brevis and $H$. spinosus, are discussed under those species. The specific name of $H$. linearis is based on the linear character of the dorsal crest.

Occurrence.-Ludvigsen collections $\mathrm{V}-3, \mathrm{~V}-4$, and V-5 from the Prongs Creek Formation, Solo Creek, Yukon Territory.

\section{Hanaites brevis n. sp. \\ Plate 9, figures 4-9}

Hanaites sp. B, Berdan in Churkin and Brabb, 1968, table 1, pl. 4, fig. 5. [Imprint 1967.]

Description.-Carapace short for genus; lateral outline slightly preplete. Hinge line straight; anterior border evenly curved; ventral border gently convex, inclined posteriorly; posterior border more sharply convex. Anterior cardinal angle more than $130^{\circ}$; posterior cardinal angle $90^{\circ}$ to $115^{\circ}$. S2 slants slightly posteriorly to midvalve or slightly below, widens and deepens ventrally, ending in rounded pit, and is bordered by narrow, smooth rim.

Velar frill narrow, reduced anterodorsally; in tecnomorph produced as small, thin, ventrally directed hooklike spur (hamus) at midheight of valves on anterior margin; in heteromorph wider anteroventrally and deflected away from free margin at about midheight, spur lacking. Antrum between velar frill and marginal ridge reticulate in both heteromorph and tecnomorph. Marginal ridge widens posteroventrally, projects from beneath velar frill posteriorly, and is deflected away from contact margin on each valve posterodorsally so that a small oval chamber, open posteriorly, is formed on the posterodorsal end of both tecnomorphic and heteromorphic carapaces.

Surface of valves deeply reticulate except for anterodorsal corner, S2, and velar frill. Row of larger reticulae at dorsal contact of velar frill and domicilium. Four to six reticulae between ventral end of S2 and velar frill. Narrow dorsal crest extends from posterodorsal end of S2 posteriorly and bends ventrally before reaching posterior cardinal angle. Posterior end of dorsal crest raised as low knob on some specimens. Narrow groove on each valve between dorsal crest and hinge line (pl. 9, fig. 8).

Material.-More than 110 specimens from the McCann Hill Chert.

Measurements.-The holotype is $1.33 \mathrm{~mm}$ long and $0.75 \mathrm{~mm}$ high. A figured paratype (USNM 173776) is $1.35 \mathrm{~mm}$ long and $0.70 \mathrm{~mm}$ high. The length and height of 54 specimens, including the holotype, are shown in figure 7.

Types.-Holotype, USNM 173777; paratypes, 170340, 173776, 173777a, 173778, 173779.

Discussion.-Hanaites brevis differs from other species assigned to Hanaites in being relatively short and stout and in having a weak, poorly developed hamus. It most closely resembles $H$. linearis n. sp. in having a linear dorsal crest on each valve, but $H$. linearis is more elongate, the dorsal crest is better developed, and there are three to four reticulae between S2 and the velar frill rather than four to six as in $H$. brevis. Also, the heteromorphic velar frill is wider in $H$. linearis than in $H$. brevis. The specific name of $H$. brevis refers to its short lateral outline.

Occurrence.-USGS collections 6492-SD, 7032SD, 7033-SD, 7037-SD, and 7038-SD, from the McCann Hill Chert, Eagle (D-1) quadrangle, Alaska.

\section{Hanaites spinosus n. sp. \\ Plate 9, figures 10-15}

Hanaites sp. A, Berdan in Churkin and Brabb, 1968, table 1, pl. 4, fig. 4. [Imprint 1967.]; Copeland in Ludvigsen, 1970, p، 426.

Description.-Carapace elongate; lateral outline preplete. Dorsal border straight; anterior border broadly rounded; ventral border straight, inclined; posterior border narrowly rounded. Anterior cardinal angle about $110^{\circ}$, posterior cardinal angle about $90^{\circ}$. Sulcation consisting of S2, which slants slightly posteriorly to midvalve, terminating in deep rounded pit. Lobation consisting of combined L1 and L2, ventral lobe, and L3, all confluent.

Velar frill continuous from somewhat above midheight on anterior margin to posterodorsal cardinal angle; widest on anterior half of valve; projecting ventrally as hooklike spur in tecnomorphs, wider and bent away from free margin anteriorly in hetero- 


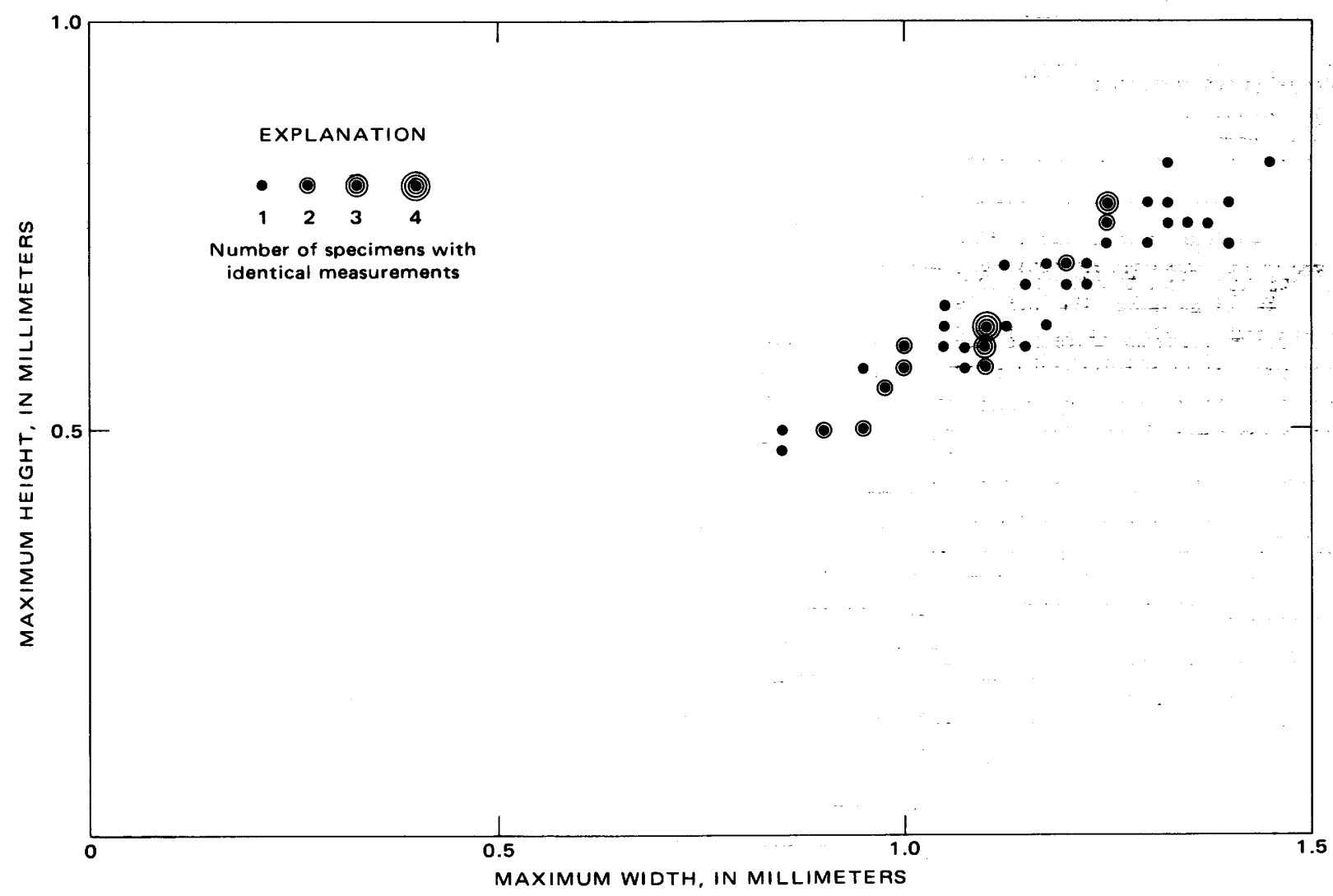

FIGURE 7.-Scatter diagram of maximum length versus maximum height for Hanaites brevis $\mathrm{n}$. sp.; 54 specimens from the McCann Hill Chert (USGS colln. 6492-SD, paratype slide 173779).

morphs. Smooth antrum between velar frill and fine marginal ridge, which projects posteriorly beyond velar frill. Dorsal ridge on left valve overreaches dorsal margin of right valve. Surface of valves, except for S2 and anterodorsal corner, deeply reticulate, with row of larger pitlike reticulae at dorsal proximal edge of velar frill. Anterodorsal corner more finely reticulate and with tendency to develop oblique ridge parallel to anterodorsal free margin. Large, blunt, posterodorsally inclined reticulate spine on L3 in posterodorsal part of valve below hinge line.

Material.-Twenty-four specimens from the McCann Hill Chert and two specimens from the Michelle Formation.

Measurements.-The holotype (USNM 173780) is $1.30 \mathrm{~mm}$ long and $0.75 \mathrm{~mm}$ high. An immature tecnomorph (USNM 173781) from the McCann Hill Chert is $1.00 \mathrm{~mm}$ long and $0.50 \mathrm{~mm}$ high. An immature tecnomorph from the Michelle Formation is $0.70 \mathrm{~mm}$ long and $0.40 \mathrm{~mm}$ high; a mature specimen (GSC 29479) from the Michelle Formation is 1.05 $\mathrm{mm}$ long and $0.60 \mathrm{~mm}$ high.

Types.-Holotype, USNM 173780; paratypes, USNM 170339, 173781, 173782, 173783, GSC 29479, 29479a.
Discussion.-Hanaites spinosus has a much more pronounced posterodorsal spine than $H$. platus (Kesling and McMillan, 1951) and is less elongate than that species. The other described species of Hanaites apparently lack the prominent posterodorsal spine. $H$. linearis $\mathrm{n}$. sp. and $H$. brevis $\mathrm{n}$. sp. may develop a low node at the posterodorsal angulation of the dorsal crest, especially in immature tecnomorphs, but this node is not as large as the spine of $H$. spinosus, nor does $H$. spinosus have the dorsal crest of these species. The spines of $H$. spinosus are better developed on the left valves of adults than they are on the right, and the presence or absence of the anterodorsal ridge appears to be variable within the species. Some specimens are nearly smooth; this may be caused by differences in preservation or may be a variation 'within the species. There is also variation in the degree of development of the ventral lobe, which is prominent in some specimens, especially small tecnomorphs. Furthermore, the posterodorsal spine is more prominent in young individuals.

Occurrence.-USGS collections 6492-SD, 7032SD, 7033-SD, 7037-SD, 7038-SD, from the McCann Hill Chert, Eagle (D-1) quadrangle, Alaska; Ludvigsen collection II-10, from the Michelle Formation, Blackstone River, Yukon Territory. 
Superfamily OEPIKELLACEA Jaanusson, 1957

Family APARCHITIDAE Jones, 1901

Genus SUBARCTICHITES n. gen.

Type species.-Subarctichites serratulus n. sp. Species included.-Aparchites crossotus Kesling, 1952.

Diagnosis.-Long hinged aparchitid ostracodes with distinct cardinal angles; free margin with row of denticles on anterior and venter but not on posterior. Velar bend smooth or denticulate. Hinge incised, of ridge and groove type. No dimorphism observed.

Discussion.-This genus probably includes numerous aparchitids described from the Devonian which have denticulate margins, but the presence or absence of marginal denticles is not mentioned in many descriptions. Subarctichites differs from Aparchites s.s. as discussed by Swartz $(1969$, p. 1239) in the character of the free margin. The anterior position of the denticles on the free margin distinguish Subarctichites from the nonsulcate and nonspinose species assigned to the dimorphic genus Gravia Polenova, 1953, in which the denticles are posterior or posteroventral. The lack of cruminal dimorphism in Subarctichites separates it from the superficially similar genera Saccarchites Swartz and Whitmore, 1956, and Phlyctiscapha Kesling, 1953. The name of the genus is based on its occurrence near, but south of, the Arctic Circle.

Geologic range.-Lower Devonian of Alaska and Yukon Territory, Middle Devonian of Michigan.

\section{Subarctichites serratulus $\mathbf{n}$. sp. \\ Plate 9, figures 16-24}

Saccarchites? sp., Berdan in Churkin and Brabb, 1968, table 1, pl. 4, fig. 15. [Imprint 1967.]

Saccarchites sp., Copeland in Ludvigsen, 1970, p. 426.

Description.-Valves subovate, amplete to slightly preplete in lateral outline. Dorsal border of left valve nearly straight; dorsal border of right valve slightly arched. Free margins evenly rounded. Greatest height and length nearly median; greatest thickness slightly posteromedian. Cardinal angles nearly equal, about $120^{\circ}$. Margin of valves with row of stout discrete spines extending from above midanterior margin to posteroventral part of valve; spines larger and more distant from contact margin on right valve. Supramarginal bend of same extent, parallel to and separated from marginal spines. Surface smooth or finely granulose. Hinge of right valve grooved; ends of hinge of left valve with notches at cardinal angles. Muscle scar is dark, round spot in central part of valve.

Material.-Thirty-six specimens from the McCann Hill Chert; six specimens from the Prongs Creek Formation.
Measurements.-The holotype is $1.20 \mathrm{~mm}$ long, $0.87 \mathrm{~mm}$ high, and $0.87 \mathrm{~mm}$ wide. The measurements of six specimens from the Prongs Creek Formation are as follows (in millimeters) : length, 1.05, height, 0.70 ; length, 1.40 , height, 1.00 ; length, 1.20 , height, 0.85 ; length, 1.40 , height, 1.00 ; length, 1.32 , height, 1.05 ; length, 1.35, height, 1.00 .

Types.-Holotype, USNM 173784; paratypes, USNM 170350, 173785, 173786, 173787, 173788, GSC 29483, 29484, 29485, 29486.

Discussion.-This species is very similar to $S u b$ arctichites crossotus (Kesling, 1952), from the Bell Shale of Michigan, in shape and presence of a marginal row of spines. S. serratulus, however, has a more elevated right dorsal margin and a marginal row of spines and a supramarginal bend instead of two rows of marginal spines like $S$. crossotus. Both species apparently have approximately the same dimensions, although the holotype of $S$. crossotus (Kesling, 1952, p. 24) is somewhat smaller than most of the specimens of $S$. serratulus. The cardinal sockets on the inside of the left valve appear to be for the reception of the cardinal angles of the right valve; no teeth or other projections have been observed in the right valve which would fit these sockets. The specific name of $S$. serratulus refers to the marginal denticles.

Occurrence.-USGS collections 6492-SD, 7032SD, 7033-SD, 7037-SD, all from the McCann Hill Chert, Eagle (D-1) quadrangle, Alaska; Ludvigsen collections V-3, V-4, from the Prongs Creek Formation, Solo Creek, Yukon Territory.

\footnotetext{
Genus LIBUMELLA Rozhdestvenskaya, 1959

Libumella sp. cf. L. discoides Rozhdestvenskaya, 1959

Plate 10, figures 1-5
}

Libumella discoides Rozhdestvenskaya, 1959, p. 134, pl. 4, figs. 1a, b.

Libumella sp., Copeland in Norris, 1967a, p. 115, 127, 138, 140; Berdan in Churkin and Brabb, 1968, table 1, pl. 4, fig. 9. [Imprint 1967.]; Copeland in Ludvigsen, 1970, p. 426.

Description.-Carapace large, subcircular in outline; length greater than height; anterior margin lower than posterior. Hinge short, incised, at midvalve. Left valve larger than right, overlapping right along entire free margin; left valve overraching right at hinge line. Each valve with thin marginal ridge. Valve surface ornamented with deep punctae except marginally and in area of circular adductor scar.

Material.-More than 80 specimens from the McCann Hill Chert; more than 60 specimens from the Prongs Creek Fo- nation.

Measurements. - Several specimens from the Prongs Creek Formation rarge from 0.95 to 1.45 
$\mathrm{mm}$ in length and from 0.80 to $1.20 \mathrm{~mm}$ in height; the length/height ratio is 1.2 .

Types. - Figured specimens, USNM 170344, 173789 ; GSC 29480, 29481.

Discussion.-These specimens may be conspecific with those described and drawn by Rozhdestvenskaya (1959, p. 134, pl. 4, figs. 1a, b) from the Biya beds (Eifelian) of Bashkiria. The punctae of the Russian specimens may be slightly larger than those of the North American specimens.

Occurrence.-USGS collections 6492-SD, 7032SD, 7033-SD, 7038-SD, from the McCann Hill Chert, Eagle (D-1) quadrangle, Alaska; Ludvigsen collections V-3, V-4, V-5 from the Prongs Creek Formation, Solo Creek, Yukon Territory.

\section{Libumella sp. cf. L. circulata Rozhdestvenskaya, 1962}

Plate 10, figures 6-8

Libumella circulata Rozhdestvenskaya, 1962, p. 179, pl. 3, figs. 3a-g.

Description.-Lateral outline subcircular to elliptical; dorsum rounded; free margins evenly curved. Narrow, subdued rim around free margins of overlapping valve continued as weak margin parallel to dorsum; overlapped valve without rim. Shell surface smooth. Hinge short, straight, apparently slightly incised.

Material.-One specimen from the McCann Hill Chert; five specimens from the Prongs Creek Formation.

Measurements.-The figured specimen from the McCann Hill Chert is $1.70 \mathrm{~mm}$ long and $1.35 \mathrm{~mm}$ high.

Types.-Figured specimens, USNM 173790, GSC 29482.

Discussion.-These specimens differ from Libumella circulata as illustrated by Rozhdestvenskaya (1962, pl. 3, figs. 3a, b) in having the rim parallel to the dorsum less well developed, and in the specimen from the McCann Hill Chert having a better developed rim around the free margins. Otherwise they appear close to figures of typical $L$. circulata.

Occurrence.-USGS collection 7032-SD, from the McCann Hill Chert, Eagle (D-1) quadrangle, Alaska; Ludvigsen collections $\mathrm{V}-3, \mathrm{~V}-4, \mathrm{~V}-5$, from the Prongs Creek Formation, Solo Creek, Yukon Territory.

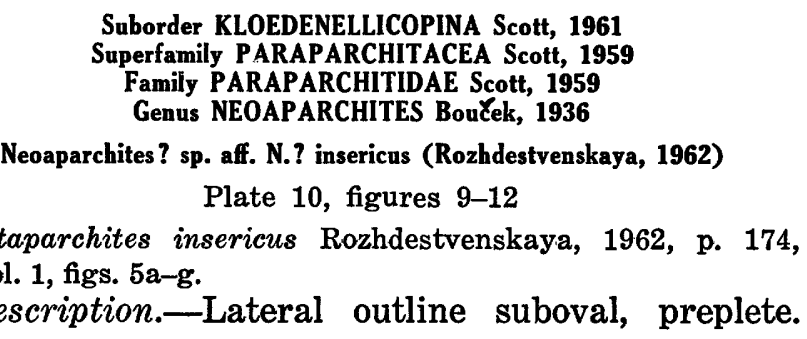

Dorsum very slightly curved; anterior and posterior ends evenly curved; ventral margin broadly curved. Hinge straight, slightly incised. Left valve overlaps right very slightly; interior of left valve channelled along free margin to receive edge of right. Surface punctate except for postcentral smooth, poorly defined muscle spot and narrow area concentric to free margins. Punctae coarser around muscle spot, becoming finer toward free margins.

Material.-One complete carapace and one right valve from the McCann Hill Chert.

Measurements.-The complete carapace is 1.70 $\mathrm{mm}$ long, $1.25 \mathrm{~mm}$ high, and $0.85 \mathrm{~mm}$ wide.

Types. - Figured specimens, USNM 173791, 173792.

Discussion.-The specimens from the McCann Hill Chert differ from Neoaparchites? insericus from the Eifelian of the southern Urals as illustrated by Rozhdestvenskaya (1962, pl. 1, figs. 5a, g) in having a smooth muscle spot and in having a gradation from the center to the margins in the size of the punctae. $N$.? insericus has been removed from Punctaparchites Kay, 1934, to which it was originally assigned by Rozhdestvenskaya, because Harris (1957, p. 261-263) has demonstrated that the type species of Punctaparchites, $P$. rugosus (Jones, 1858) was incorrectly oriented and is a podocopid. However, N.? insericus is only questionably assigned to Neoaparchites Boucek, 1936, because, although Boucek (1936, p. 39) stated that Neoaparchites was proposed for species of Aparchites with rounded cardinal angles, the original illustration and description of the type species, Primitia obsoleta Jones and Holl, 1865 , indicate the presence of an obtuse but welldeveloped posterior cardinal angle. Further study of Neoaparchites obsoletus is required to clarify the characteristics of the genus.

Occurrence._USGS collections 6492-SD, 7032SD from the McCann Hill Chert, Eagle (D-1) quadrangle, Alaska.

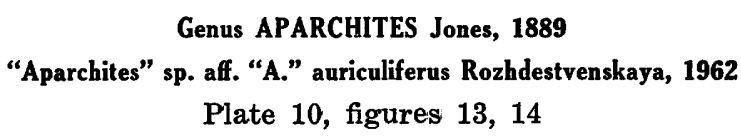

Genus APARCHITES Jones, 1889

“Aparchites" sp. aff. “A.” auriculiferus Rozhdestvenskaya, 1962

Plate 10, figures 13, 14

Aparchites auriculiferus Rozhdestvenskaya, 1962, p. 171172 , pl. 1, figs. 1a, b; 2a, b.

Description.-Lateral outline subcircular; dorsum straight, forming chord across circular outline of free margins. Hinge slightly incised; cardinal angles obtuse but distinct. Valves equal; essentially no overlap on free margins. No marginal structures. Shell surface smooth.

Material.-One incomplete carapace from the McCann Hill Chert.

Measurements.-The single specimen is $1.85 \mathrm{~mm}$ long, $1.65 \mathrm{~mm}$ high, and $1.10 \mathrm{~mm}$ wide. 
Types.-Figured specimen, USNM 173793.

Discussion.-The specimen from the McCann Hill Chert appears to have a somewhat shorter hinge line than the specimens from the Eifelian beds of the southern Urals and western Bashkiria figured by Rozhdestvenskaya but is otherwise similar. Swartz (1969, p. 1238-1239), in restudying the type species of Aparchites, A. whiteavesi Jones, 1889, has suggested that the genus Aparchites be restricted to those species, that resemble the type species in having inward bending and thickening of the free margins. This type of marginal structure is not present in "A." auriculiferus nor in the probably related species "A." chuchlensis Přibyl, 1952. These species appear to constitute a new genus in the Paraparchitacea, but additional material is necessary before such a genus is described.

Occurrence.-USGS collection 7032-SD, from the McCann Hill Chert, Eagle (D-1) quadrangle, Alaska.

\footnotetext{
Superfamily KLOEDENELLACEA Ulrich and Bassler, 1908 Family KLOEDENELLIDAE Ulrich and Bassler, 1908 Genus EUKLOEDENELLA Ulrich and Bassler, 1923
}

Eukloedenella recta n. sp.

Plate 11, figures 19-24

?Eukloedenella sp., Copeland in Norris, 1967a, p. 138; Copeland in Ludvigsen, 1970, p. 426 [part].

Description.-Lateral outline subovate to subquadrate, amplete to slightly postplete; dorsal outline of heteromorphic carapace subtriangular; tecnomorphs lanceolate in dorsal view. Dorsal and ventral margins subparallel; anterior margin evenly rounded; posterior margin straight to slightly convex. Posterior cardinal angle curved, but projection of dorsal and posterior margins meeting at about $90^{\circ}$. Essentially equivalved, but right valve overlaps left slightly around free margins. Stragulum on right valve overlaps left valve from anterior cardinal angle to midlength of carapace; hinge behind stragulum slightly incised. Greatest height and length near midpoint of carapace; greatest width posterior. S2 deep, elongated, pitlike. No indication of S1. Surface with some punctae or smooth.

Material.-Four specimens from the Michelle Formation; 1 carapace and 10 single valves from the McCann Hill Chert.

Measurements.-The three figured carapaces from the Michelle Formation are $0.95 \mathrm{~mm}$ long, $0.60 \mathrm{~mm}$ high, and $0.52 \mathrm{~mm}$ wide; $0.80 \mathrm{~mm}$ long, $0.50 \mathrm{~mm}$ high, and $0.42 \mathrm{~mm}$ wide; $0.90 \mathrm{~mm}$ long, $0.60 \mathrm{~mm}$ high, and $0.50 \mathrm{~mm}$ wide, respectively.

Types.-Holotype, GSC 29443; paratypes, GSC 29444, 29445, 29446, USNM 173794, 173795.

Discussion.-Most of the specimens are hetero- morphic; a few tecnomorphic single valves are less abruptly truncated posteriorly in dorsal view and have a more lanceolate outline. Eukloedenella recta belongs to the group of $E$. umbilicata Ulrich and Bassler, 1923, the type species of the genus. However, it differs from other species assigned to this group by Ulrich and Bassler (1923, p. 669-671) by its wide, truncated dorsal outline and right-over-left overlap. E. dalhousiensis Copeland, 1962 is also similar to $E$. recta, but according to Copeland (1962, p. 42 , pl. 10 , figs. 2,3 ) the stragulum of $E$. dalhousiensis is narrow and on the left valve, although the right valve has a slight angulation over the left immediately above the median sulcus. The specific name of $E$. recta refers to the straight or rectangular outline of the species.

Occurrence.-Ludvigsen collections II-10, II-11 from the Michelle Formation, Blackstone River, Yukon Territory; USGS collections 7032-SD, 7033-SD, 7037-SD from the McCann Hill Chert, Eagle (D-1) quadrangle, Alaska.

\section{Eukloedenella soloensis $n$. sp. \\ Plate 11, figure 28}

?Eukloedenella sp., Copeland in Ludvigsen, 1970, p. 426 (part).

Description.-Lateral outline subovate, postplete, with strong posterior inflation extending above hinge line. Posterior margin more broadly rounded than anterior. Slight indication of S1. S2 anterior of midvalve (1.0 $\mathrm{mm}$ from anterior end), deep, slitlike, not extending to dorsum. Posteroventral margin flattened, flangelike. Surface finely punctate. Interior showing fold of S1 and well-defined subovate depression of L2.

Material.-One heteromorphic? right valve.

Measurements.-The type specimen is $2.30 \mathrm{~mm}$ long and $1.50 \mathrm{~mm}$ high.

Type.-Holotype, GSC 29442.

Discussion.-This species is similar in lateral outline to Eukloedenella sulcifrons Ulrich and Bassler, 1923, as emended by Swartz (1933, female specimens, pl. $30,6 \mathrm{a}, \mathrm{d})$ but the sulcus of $E$. soloensis is more slitlike and the surface is punctate. Swartz (1933, p. 258) indicated that some specimens of $E$. sulcifrons have "a suggestion of a shallow undefined anterior sulcus" like that present on $E$. soloensis. $E$. punctillosa Ulrich and Bassler, 1923, is also similar to $E$. soloensis in lateral outline but is more regularly punctate and has a deeper sulcus. $E$. soloensis is unusually large for a species of Eukloedenella.

Occurrence.-Ludvigsen collection V-3, from the Prongs Creek Formation, Solo Creek, Yukon Territory. 


\author{
Genus POLONIELLA Gürich, 1896 \\ Subgenus FRAMELLA Weyant, 1968 \\ Poloniella (Framella) sp. aff. P. (F.) scheii Weyant, 1968 \\ Plate 11, figures 25-27
}

Poloniella (Framella) scheii Weyant, 1968, p. 103-104, pl. 1, figs. 4, 5.

Description.-Lateral outline amplete to slightly preplete. Dorsal margin in lateral view slightly sinuous to straight; anterior margin smoothly curved; ventral margin weakly concave; posterior margin more sharply curved than anterior margin. Narrow marginal sulcus connects dorsally with $\mathrm{S} 1$ and posteroventrally with S3. S1 about half height of valve, narrowed ventrally, inclined anteriorly; S2 also about half height of valve, narrow, more slanted anteriorly than S1; S3 arcuate, concave anteriorly, extending from dorsal margin nearly to ventral margin where it connects with marginal sulcus. L1 ovate in outline; L2 sinuous, narrow ventrally, slanted anteriorly and with a dorsoposterior extension; L3 large, slanted anteriorly, curved posteriorly, with narrow, shallow diagonal groove inclined anteriorly ; L4 crescentic, narrow, concave anteriorly. Surface smooth. Stragular process poorly developed. Heteromorph not known.

Material.-Five specimens, comprising four left and one right tecnomorphic valves, from the McCann Hill Chert.

Measurements.-Two figured specimens are 0.60 $\mathrm{mm}$ long and $0.30 \mathrm{~mm}$ high, and $0.67 \mathrm{~mm}$ long and $0.35 \mathrm{~mm}$ high, respectively.

Types.-Figured specimens USNM 173796, 173797, 173798.

Discussion.-These specimens are most like the tecnomorphs of Poloniella (Framella) scheii described and illustrated by Weyant $(1968$, p. 103 , pl. 1, fig. 5), from the lower part of the Blue Fiord Formation of Ellesmere Island. However, the specimens from the McCann Hill Chert differ from Weyant's specimens in the presence of the diagonal groove on L3.

Occurrence.-USGS collection 7037-SD, from the McCann Hill Chert, Eagle (D-1) quadrangle, Alaska.

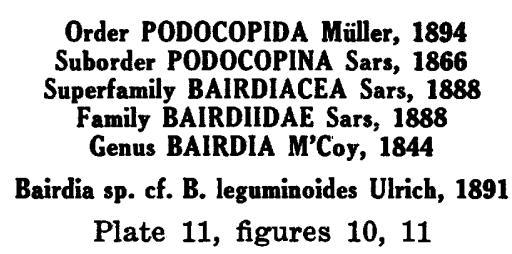

Bairdia leguminoides Ulrich, 1891, p. 197, pl. 17, figs. 5ac; (for a complete synonymy see Sohn, 1960 [1961], p. 29).

Description.-Carapace elongate, spindle-shaped, with short straight hinge line and dorsally inclined acuminate ends prolonged as spines on larger left valve. Posterior end more acute. Left valve overlaps right all around. Dorsal and ventral borders convex. Both valves inflated, maximum thickness near middle of valve. Surface smooth, possibly with some punctae.

Material.-Two specimens from the Prongs Creek Formation, three specimens from the McCann Hill Chert.

Measurements.-The figured specimen from the Prongs Creek Formation is $1.20 \mathrm{~mm}$ long and 0.50 $\mathrm{mm}$ high; the figured specimen from the McCann Hill Chert is $1.15 \mathrm{~mm}$ long, $0.55 \mathrm{~mm}$ high, and 0.45 mm wide.

Types.-Figured specimens, GSC 29508, USNM 173799.

Discussion.-The specimens from the McCann Hill Chert have a longer hinge than the holotype of Bairdia leguminoides Ulrich, 1891 (USNM 41788), and also appear to have a slight ventral flattening. They differ from B. mucronata Rozhdestvenskaya, 1960, in lacking a marked ventral overlap, and differ from B. emaciata Kesling and Kilgore, 1952, in being less elongate.

Occurrence.-Ludvigsen collections $\mathrm{V}-3$ and V-5 from the Prongs Creek Formation, Solo Creek, Yukon Territory; USGS collections 7032-SD, 7037-SD, and 7038-SD from the McCann Hill Chert, Eagle (D-1) quadrangle, Alaska.

\section{Bairdia dejecta n. sp. \\ Plate 11, figures 1-4}

Description.-Lateral outline bairdioid; dorsum curved; dorsoanterior margin long and nearly straight; dorsoposterior margin short and concave; ventroanterior and ventroposterior margins gently curved; ventral margin slightly concave. Carapace narrow and fusiform in dorsal outline. Left valve overlaps right all around. Dorsoanterior and dorsoposterior margins of left valve prolonged as downward slanting spines. Shell surface smooth.

Material.-One complete and one broken carapace from the McCann Hill Chert.

Measurements.-The holotype is $1.40 \mathrm{~mm}$ long, $0.55 \mathrm{~mm}$ high, and $0.40 \mathrm{~mm}$ wide.

Types. - Holotype, USNM 173800; paratype, USNM 173801.

Discussion.-This species differs from other species of Bairdia in having the terminal spines directed obliquely downward rather than upward as in the group of Bairdia leguminoides Ulrich, 1891. The specific name refers to the downcast appearance of the specimens. 
Occurrence.-USGS collection 7037-SD, from the McCann Hill Chert, Eagle (D-1) quadrangle, Alaska.

\section{Genus RECTOBAIRDIA Sohn, 1961 \\ Rectobairdia sp. \\ Plate 11, figure 15}

Description.-Lateral outline bairdioid; dorsum straight, more than half length of valve. Dorsoanterior margin concave, meeting smoothly curved ventroanterior margin at an angle above midheight of valve. Ventral margin slightly concave. Dorsoposterior margin concave, meeting smoothly curved ventroposterior margin at an acute angle about midheight of valve. Dorsal outline of valve smoothly curved. Surface smooth.

Material.-One left valve from the McCann Hill Chert.

Measurements.-The figured specimen is $1.20 \mathrm{~mm}$ long and $0.52 \mathrm{~mm}$ high.

Types.-Figured specimen, USNM 173802.

Discussion.-The long straight dorsum indicates that this specimen should be assigned to the genus Rectobairdia Sohn, 1961.

Occurrence.-USGS collection 6492-SD from the McCann Hill Chert, Eagle (D-1) quadrangle, Alaska.

\section{Genus BAIRDIOLITES Croneis and Gale, 1939 \\ Bairdiolites? sohni n. sp. \\ Plate 11, figures 5, 6, 9}

Description.-Lateral outline fusiform; dorsum curved. Dorsoanterior and dorsoposterior margins straight to slightly concave; ventroanterior margin gently curved; ventral margin straight to slightly convex; ventroposterior margin nearly straight. Left valve overlaps right all around. Anterior and posterior ends sharply acuminate, extended as spines on larger left valve. Both valves with vertical shoulders or ridges on anterior and posterior quarters. Dorsal outline subfusiform, with parallel sides. Surface smooth. Duplicature well developed. Muscle scar round.

Material.-One carapace and three valves, all from the McCann Hill Chert.

Measurements.-The holotype is $1.25 \mathrm{~mm}$ long, $0.47 \mathrm{~mm}$ high, and $0.40 \mathrm{~mm}$ wide.

Types.-Holotype, USNM 173803; paratypes, USNM 173804, 173805, 173806.

Discussion.—Bairdiolites? sohni superficially resembles Bairdia leguminoides Ulrich, 1891, because of its acuminate or spinose ends, but differs in having the two characteristic vertical ridges and a more rounded dorsum. This species is only questionably assigned to Bairdiolites because the other described species of Bairdiolites lack the very acuminate ends of B.? sohni. Bairdiolites has previously been considered to range from the Late Mississippian into the Early Pennsylvanian (Sohn, 1960 [1961], p. 6970) ; however, two Middle Devonian species illustrated by Rozhdestvenskaya (1962, pl. 21, figs. 3a-v, 4a-b), Bairdia transversocostata Rozhdestvenskaya, 1962, and Bairdia navicula Martinova and Polenova, 1955, may belong in Bairdiolites rather than Bairdia.

Occurrence.-USGS collections 6492-SD, 7037SD, from the McCann Hill Chert, Eagle (D-1) quadrangle, Alaska.

\section{Genus NEWSOMITES Morris and Hill, 1952 \\ Newsomites? sp. \\ Plate 14, figures 17,18}

Description.-Lateral outline ovate, preplete; dorsum gently curved; anterior margin broadly rounded; ventral margin gently curved; posterior margin sharply curved. Dorsal outline oval; maximum width median. Hinge incised; larger left valve overlaps anterior and posterior ends of right valve. In end view, carapace tumid and asymmetrical ; left valve markedly larger than right, overlaps and overreaches right ventrally. Surface smooth.

Material.-One carapace from the McCann Hill Chert.

Measurements.-The figured specimen is $0.47 \mathrm{~mm}$ long, $0.32 \mathrm{~mm}$ high, and $0.40 \mathrm{~mm}$ wide.

Types.-Figured specimen, USNM 173847.

Discussion.-The preplete lateral outline suggests that this may be a juvenile specimen. The normal pore canals reported by Lundin and Newton (1970, p. 33, 34) for Newsomites pertumidus Morris and Hill, 1952, and $N$. profusus Lundin and Newton, 1970 , have not been observed in the specimen from the McCann Hill Chert; they have probably been obliterated by this type of silicification. Although Newsomites was originally described from the Silurian of the Eastern United States, Polenova (1968, p. 72-74) has included in this genus a species and three subspecies from the Devonian of Siberia, extending its range to Middle Devonian.

Occurrence.-USGS collection 7037-SD from the McCann Hill Chert, Eagle (D-1) quadrangle, Alaska.

Family BEECHERELLIDAE Ulrich, 1894 Genus ACANTHOSCAPHA Ulrich and Bassler, 1923 Acanthoscapha sp.

Plate 11, figures 12-14

Description.-Lateral outline subfusiform; dorsum long, slightly concave at either end, terminating in spines; anterior margin more sharply curved 
than posterior margin; ventral margin slightly concave. Hinge line more than half length of carapace; left valve slightly overreaches right dorsally and overlaps right in ventral concavity. Anteroventral and posteroventral margins of both valves meet as flattened flange. Posterior terminal spine on left valve nearly parallel to hinge line, anterior terminal spine inclined slightly upward. Dorsal outline fusiform. Shell surface smooth.

Material.-One poorly preserved carapace from the McCann Hill Chert.

Measurements.-The figured specimen is $1.25 \mathrm{~mm}$ long, $0.35 \mathrm{~mm}$ high, and $0.32 \mathrm{~mm}$ wide.

Types.-Figured specimen, USNM 173807.

Discussion.-This single carapace is close to Acanthoscapha navicula (Ulrich, 1891) from the Kalkberg Limestone of eastern New York, but is too poorly preserved to identify specifically.

Occurrence.-USGS collection 7037-SD from the McCann Hill Chert, Eagle (D-1) quadrangle, Alaska.

Genus SHIDELERITES Morris and Hill, 1951

Type species.-Shidelerites typus Morris and Hill, 1951.

Species included.-Shidelerites yukonensis n. sp.

Revised diagnosis. - Asymmetrical beecherellid ostracodes with upright or posteriorly slanted spine on anterodorsal end of larger left valve, acuminate posterior, and laterally compressed anteroventral and posteroventral marginal areas.

Discussion.-Morris and Hill (1951, p. 698) oriented Shidelerites with the anterior spine pointed downward in an anteroventral position, and compared the genus to the Cypridinidae but noted that it lacks the opening for protrusion of the anterior appendages characteristic of that family. Later, Triebel (1961, p. 347-348) examined topotype specimens and suggested that the genus should be reoriented so that the spine is anterodorsal in position and the sinuous margin is ventral. He proposed a revised diagnosis for Shidelerites (Triebel, 1961, p. 348) which is freely translated as follows:

Carapace middle sized, without distinct sculpture, spindleshaped in dorsal outline, elongated in lateral view, height less than half length. Anterior end broadly rounded, posterior end drawn out into a sharp process that is somewhat below the straight hinge line. Dorsal margin of left valve with a triangular upward-pointing process on the anterior, which is lacking on the right (valve). Ventral margin slightly bent in before the middle, projecting to the ends in flat arcs. Carapace in these parts somewhat compressed, in the remaining (parts) approximately evenly arched. Left valve larger than right, very widely overreaching at the anterodorsal margin with its triangular process, less overreaching on the remaining dorsal margin, somewhat overlapping ventrally in the oral region. Along the anterior margin and the terminal part of the ventral margin the valves lie simply together. Inner characters unknown.

Triebel $(1961$, p. 349) noted that Shidelerites had been tentatively referred to the Bairdiidae by Betty Kellett Nadeau (note in Morris and Hill, 1951, p. 699) and stated that no better classification could be made until the internal characters of the valves were known. Having noted the resemblance of Shidelerites to Acanthoscapha Ulrich and Bassler, 1923 (=Allanella Bouček, 1936; see Berdan, 1960, p. 471), Triebel (1961, p. 349) concluded that Acanthoscapha also should be assigned to the Bairdiidae rather than the Beecherellidae. His reasons for removing Acanthoscapha from the Beecherellidae were based on the flattened venter of Beecherella as opposed to the laterally compressed ventral margins of Acanthoscapha, the hollow ventroterminal spines of Beecherella as opposed to the dorsoterminal spines of Acanthoscapha, and the resemblance of Acanthoscapha to Bairdia. In our opinion, the flattened venter of Beecherella should not be considered a family characteristic, because this feature appears at random in otherwise unrelated stocks. Acanthoscapha may well be ancestral to Bairdia, but should be retained in the Beecherellidae because of its long straight hinge line and attenuated outline. In addition to Shidelerites, Scaphina Polenova, 1968 and Celechovites Pokorný, 1950, should be included in the Beecherellidae, as suggested by Polenova (1968, p. 54). These genera all resemble Beecherella in having a long straight hinge line and height less than half the length of the valves.

To facilitate comparison with Shidelerites yukonensis n. sp., the holotype (USNM 116420) and a paratype (USNM 116421a) of Snidelerites typus Morris and Hill, 1951, are illustrated with the revised orientation on plate 11 , figures 16,17 .

Geologic range.-Waldron Shale (Middle Silurian) of Indiana; Prongs Creek Formation (Lower Devonian) of Yukon Territory.

\section{Shidelerites yukonensis $n$. $\mathbf{s p .}$ \\ Plate 11, figure 18}

Description.-Carapace elongate in lateral view, acuminate at each end; fusiform in dorsal view; oval in end view. Left valve larger than right, overreaching it dorsally and overlapping it midventrally and posteroventrally. Greatest height in posterior half, excepting anterior spine; greatest length in dorsal half. Hingeline straight, in anterior three-fourth of valve. Posterodorsal margin sloping ventrally to acuminate posterior cardinal corner, slightly concave; posteroventral margin evenly curved to midventer. Ventral margin concave at midlength, curv- 
ing smoothly into anteroventral and posteroventral margins. Anteroventral margin gently curved to meet vertical anterior margin. Anterior cardinal angle of right valve with slight dorsal angulation; anterior cardinal angle of left valve wrapped around that of right valve and produced into strong vertically directed spine or horn. Lateral surface smooth; anteroventral and posteroventral areas slightly concave parallel with the free margin, anteroventral area apparently larger. Internally, duplicature visible through hole in left valve continuous at least in posterior half of valve as fine shelflike thickening of free margin.

Material. - One complete carapace from the Prongs Creek Formation.

Measurements.-The holotype is $1.55 \mathrm{~mm}$ long and $0.60 \mathrm{~mm}$ high.

Types.-Holotype, GSC 29440.

Discussion.-Shidelerites yukonensis differs from $S$. typus Morris and Hill, 1951, the type species of the genus, in having the anterior margin nearly vertical rather than smoothly curved, and in having the anterodorsal spine erect rather than slanted posteriorly.

Occurence.-Ludvigsen collection V-3, Prongs Creek Formation, Solo Creek, Yukon Territory.

\section{Genus BEECHERELLA Ulrich, 1891 \\ Beecherella? sp.}

Plate 11, figures 7,8

Description.-Lateral outline subtrapezoidal; both ends acuminate; greatest length ventral; greatest height in anterior quarter. Hinge line straight, not parallel to ventral margin, sloping slightly posteriorly. Venter flat, extended laterally as ala with minute posteriorly directed spine. Dorsal outline subtriangular. Shell surface smooth. Duplicature poorly developed.

Material.-One right valve from the McCann Hill Chert.

Measurements.-The figured specimen is $0.55 \mathrm{~mm}$ long, $0.25 \mathrm{~mm}$ high, and $0.25 \mathrm{~mm}$ wide.

Types.-Figured specimen, USNM 173808.

Discussion.-This single right valve is suggestive of Beecherella in its lateral outline and flattened venter, but the relatively short hinge, poorly developed duplicature, and wide alate process are not typical of the genus Beecherella as represented by the type species, $B$. carinata Ulrich, 1891 . The flattened venter and alate process are like similar structures developed in the genus Pseudocyproides Morris and Hill, 1952, but the type species of this genus, $P$. alatus, is described by Morris and Hill (1952, p. 16, pl. 1, fig. 4) as having a strongly arched dorsum.
Examination of the holotype of $P$. alatus Morris and Hill, 1952 (USNM 123230) suggests that the resemblance is homeomorphic.

Occurrence.-USGS collection 7037-SD, from the McCann Hill Chert, Eagle (D-1) quadrangle, Alaska.

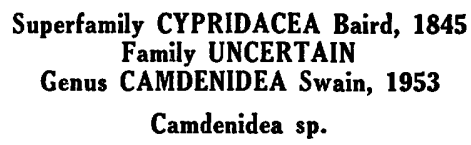

Plate 13, figures 1-4

Description.-Lateral outline subreniform; dorsal margin smoothly curved, merging with more sharply curved anterior margin; ventral margin straight to concave; posterior margin acuminate. Dorsal outline subelliptical. Right valve overlaps left around free margins; left valve with crescentic depressed areas on anterior and posterior margins which are absent on right valve. Surface smooth. Duplicature narow.

Material.-Two left valves, one right valve, and one carapace from the McCann Hill Chert.

Measurements.-The carapace is $0.55 \mathrm{~mm}$ long, $0.27 \mathrm{~mm}$ high, and $0.32 \mathrm{~mm}$ wide.

Types.-Figured specimens, USNM 173812, 173813, 173814.

Discussion.-These small specimens differ from Camdenidea camdenensis Swain, 1953, the type species of the genus, in having the right valve larger than the left and in having anteroventral and posteroventral compressed areas on the left valve only. A formal name is not proposed for them here because of the probability that they are immature individuals.

Occurrence.-USGS collection 7037-SD from the McCann Hill Chert, Eagle (D-1) quadrangle, Alaska.

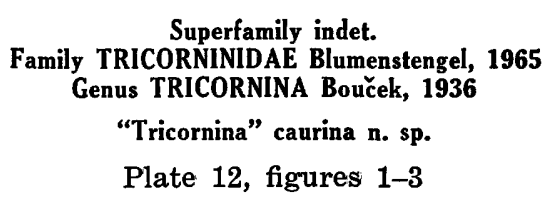

Description. - Carapace boat-shaped; greatest length along dorsal margin; posterior cardinal angle acuminate; posteroventral margin sloping to relatively straight ventral margin; anterior cardinal angle more than $90^{\circ}$, anterior margin broadly rounded. Anterior and posterior margins with narrow marginal flange. Surface smooth, evenly curved from lateral margins to very long hollow spine at midvalve. Spine base large, diameter about threequarters height of valve; spine extending at right angles to valve, tapering distally with slight dorsal and posterior swing. 
Material.-One right valve from the Prongs Creek Formation.

Measurements.-The holotype is $1.35 \mathrm{~mm}$ long and $0.60 \mathrm{~mm}$ high. The spine is $0.85 \mathrm{~mm}$ long.

Types.-Holotype, GSC 29448.

Discussion.-The size and orientation of the lateral spine of this species is extremely distinctive. The anterodorsal corner of the valve is slightly broken so it is impossible to determine if an anterodorsal spine or projection should be present.

Occurrence.-Ludvigsen collection V-3, from the Prongs Creek Formation, Solo Creek, Yukon Territory.

\section{Tricornina sp.}

Plate 12, figure 4

Description.-Valve boat-shaped; dorsal margin greatest length; posterior angle acuminate; anterior angle with strong, dorsally directed spine. Surface smooth, with long straight only slightly tapering spine near midventral part of valve. Spine projects posterolaterally at about $45^{\circ}$ to the valve surface.

Material.-One small incomplete (now broken) left valve from the Michelle Formation.

Measurements.-Specimen broken, not measured.

Types.-Figured specimen, GSC 29510.

Discussion.-This specimen is too poorly preserved for adequate comparison with other tricorninids. It has the general features of the genus.

Occurrence.-Ludvigsen collection I-3 from the Michelle Formation, Hart River, Yukon Territory.

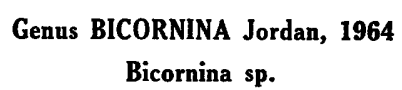

Plate 12, figures 5-7

Description.-Lateral outline boat-shaped; dorsal margin straight to slightly convex; free margins smoothly curved. Anterior cardinal angle acute, produced as spine on larger left valve; posterior cardinal angle blunt or rounded. Dorsal outline arrowshaped; posteroventral half of both valves occupied by large hollow spine which projects posteriorly and curves dorsally, extending beyond posterior margin of carapace. Shell surface smooth. No duplicature.

Material.-One broken, poorly preserved carapace, two left valves, and one right valve from the McCann Hill Chert.

Measurements.-The figured left valve is $0.65 \mathrm{~mm}$ long without the anterior spine and $0.35 \mathrm{~mm}$ high. The length, including both spines, is $0.85 \mathrm{~mm}$.

Types.-Figured specimens, USNM 173809, 173810.

Discussion.-Jordan (1964, p. 58-59) distinguished Bicornina from Tricornina Bouček, 1936 on the basis that Bicornina lacks the posterodorsal spine of Tricornina. The blunt posterior angle of the specimens from the McCann Hill Chert suggests that they belong in Bicornina.

Occurrence.-USGS collections 6492-SD, 7032SD, 7037-SD, 7038-SD from the McCann Hill Chert, Eagle (D-1) quadrangle, Alaska.

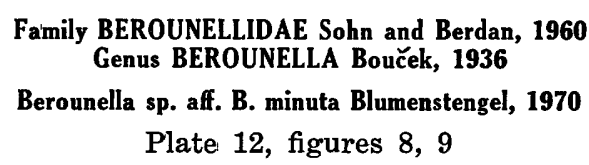

Berounella minuta Blumenstengel, 1970, p. 19-20, pl. 1, figs. $10,11$.

Description.-Lateral outline subtrapezoidal; dorsal margin straight to slightly concave; ventral margin straight, parallel to dorsal margin; anterior margin slightly sinuous; posterior margin concave, curving posteriorly parallel to dorsal margin. Posterior end of valve drawn out into long hemitube characteristic of genus. Valve trilobate; L1 nearly vertical, extending from anterodorsal to anteroventral margins of valve; L2 knoblike, anteromedian in position; L3 curved obliquely forward. L3 with long hollow spine arising from ventral part and projecting posteriorly and slightly dorsally. Small spine at midheight of posterior margin. Three, possibly four, small digitate spines on anterodorsal part of anterior margin. Anteroventral and posteroventral margins slightly flattened. Duplicature best developed on anterior and posterior margins.

Material.-One right valve from the McCann Hill Chert.

Measurements.-The figured specimen is $0.95 \mathrm{~mm}$ long, including the spine, and $0.30 \mathrm{~mm}$ high.

Types.-Figured specimen, USNM 173811.

Discussion.-The single right valve from the McCann Hill Chert resembles Berounella minuta Blumenstengel, 1970, in having a long prominent spine on L3, which is apparently not as well developed, if present, on the other species of Berounella listed by Blumenstengel $(1965$, p. 56). However, our specimen differs from $B$. minuta in the arrangement of the anterodorsal spines. Blumenstengel (1970, p. 19, pl. 1, fig. 10) described and illustrated $B$. minuta as having a prominent anterodorsal spine which curves upward and forward, and a second smaller spine beneath this. Our specimen has three short spines on the anterodorsal part of the anterior margin. A fourth may have been present and then broken off, but it could not have been as prominent as the anterodorsal spine shown by Blumenstengel.

Occurence.-USGS collection 7037-SD, from the McCann Hill Chert, Eagle (D-1) quadrangle, Alaska. 


\section{Suborder METACOPINA Sylvester-Bradley, 1961 \\ Superfamily HEALDIACEA Harlton, 1933 \\ Family BAIRDIOCYPRIDIDAE Shaver, 1961 Genus BAIRDIOCYPRIS Kegel, 1932}

Bairdiocypris? sp. cf. B.? cordiformis Rozhdestvenskaya, 1959

Plate 12, figures 10, 11

Bairdiocypris (?) cordiformis Rozhdestvenskaya, 1959, p. 167, pl. 25, figs. 1a, b; 2a, b.

Description.-Carapace reniform to heart-shaped; greatest length in ventral third; greatest height slightly anterior of midlength. Left valve overlaps right along dorsal margin; greatest overlap posterodorsal. Right valve with low marginal flange at anteroventral and posteroventral corners; flange not present midventrally where both valves are slightly concave.

Material._One carapace from the Prongs Creek Formation and one from the McCann Hill Chert.

Measurements.-The specimen from the Prongs Creek Formation is $0.90 \mathrm{~mm}$ long and $0.70 \mathrm{~mm}$ high.

Types.-Figured specimens, GSC 29450, USNM 173840.

Discussion.-The figured specimens are very similar to Bairdiocypris? cordiformis from the Biya beds (Eifelian) of Bashkiria; the Yukon specimen, however, has its greatest height slightly anterior of midvalve, that of $B$.? cordiformis is slightly posterior of midvalve.

Occurrence.-Ludvigsen collection V-3 from the Prongs Creek Formation, Solo Creek, Yukon Territory; USGS collection 7037-SD from the McCann Hill Chert, Eagle (D-1) quadrangle, Alaska.

\section{Bairdiocypris sp. \\ Plate 12, figure 12}

"Bythocypris" sp., Copeland in Norris, 1967a, p. 128, 130, $138,140,141$.

Description.-Carapace subovate in lateral view, slightly concave midventrally, regularly convex dorsally. Left valve overlapping right along all margins; least overlap at anteroventral margin. Hinge curved, about one-third greatest length, inclined posteroventrally, and situated in posterior half of valve. Surface smooth.

Material.-More than 10 specimens from the Prongs Creek Formation.

Measurements.-The figured specimen is $1.20 \mathrm{~mm}$ long and $0.80 \mathrm{~mm}$ high.

Types.-Figured specimen, GSC 29476.

Discussion.-Some variation in overlap occurs in this species, some specimens showing more left-overright overlap posteroventrally. In general, however, the greatest overlap is as indicated above.

Occurrence.-Ludvigsen collections V-3, V-4, V-5, Prongs Creek Formation, Solo Creek, Yukon Territory.
Genus KURESAARIA Adamczak, 1967

Kuresaaria blackstonensis n. sp.

Plate 12, figures 13-25

Bairdiocypris sp., Berdan in Churkin and Brabb, 1968, table 1, pl. 4, fig. 8 [imprint 1967]; Copeland in Ludvigsen, 1970, p. 426 (part).

Description.-Carapace subovate to subtriangular in lateral view; anterior and posterior margins evenly rounded; dorsal margin highly arched; ventral margin convex. Carapace fusiform in dorsal view. Left valve larger than right, overlapping right all around; greatest overlap along dorsum and venter. Valves moderately convex, smooth; greatest thickness median in ventral half. Hinge straight, sloping posteriorly, about one-half greatest length of valve, consisting of simple groove and ridge hingement. Left valve with contact groove terminating in two ventral stop ridges, not present midventrally. Right valve more angular than left. Hinge of right valve prominent, with abrupt terminal angulations; anterior margin extended ventrally, ventral margin sloping upward to regularly curved posterior margin. Muscle scar on median inner surface, circular in outline but less distinct on its dorsal edge, apparently consisting of numerous small scars. Shell very thick.

Material._Nine specimens from the Michelle Formation; three specimens from the Prongs Creek Formation; more than 90 specimens from the McCann Hill Chert.

Measurements.-Three left valves from the $\mathrm{Mi}$ chelle Formation are $1.35 \mathrm{~mm}$ long and $0.95 \mathrm{~mm}$ high, $1.02 \mathrm{~mm}$ long and $0.70 \mathrm{~mm}$ high, and $1.10 \mathrm{~mm}$ long and $0.75 \mathrm{~mm}$ high, respectively. Two right valves from the Michelle Formation are $1.32 \mathrm{~mm}$ long and $0.80 \mathrm{~mm}$ high, and $1.25 \mathrm{~mm}$ long and 0.78 $\mathrm{mm}$ high, respectively.

Types.-Holotype, GSC 29487; paratypes, GSC 29488, 29489, 29490, 29491, 29492, 29493, USNM 170343, 173815, 173816, 173817, 173818.

Discussion.-This species is considered to belong in Kuresaaria because of the character of the contact groove and ventral stop ridges, although the hinge is straighter than that of typical Kuresaaria. It differs from $K$. gotlandica Adamczak, 1967, the type species of the genus, in having the greatest height more median and lacking the shallow anterodorsal depression of $K$. gotlandica. An unusually thick shell has been demonstrated for $K$. gotlandica by Adamczak (1967, figs. 3C, D) ; this condition prevails in $K$. blackstonensis also. One specimen (pl. 12, fig. 23) from the McCann Hill Chert, which is imperfectly silicified, shows structures that appear to be siliceous fillings of small pore canals in the shell 
wall. These are smaller and more closely spaced than those of the pachydomellids.

Occurrence.-USGS collections 6492-SD, 7032SD, 7033-SD, 7037-SD, and 7038-SD from the McCann Hill Chert, Eagle (D-1) quadrangle, Alaska; Ludvigsen collections II-10, II-13, II-14, and IV-3 from the Michelle Formation, Blackstone River, Yukon Territory; Ludvigsen collection V-3 from the Prongs Creek Formation, Solo Creek, Yukon Territory.

\section{Genus BAIRDIOHEALDITES McGill, 1968 \\ Bairdiohealdites? scapulatus n. sp. \\ Plate 13, figures 8-11}

Description.-Lateral outline subreniform; dorsal outline sublanceolate. Dorsal margin smoothly curved, sloping abruptly into short, straight posterodorsal margin; posteroventral margin sharply curved; ventral margin straight to slightly concave; anterior margin sharply curved, merging smoothly into gently curved anterodorsal slope. Left valve overlaps right around free margins, overreaches right along straight hingeline. Greatest height median to posteromedian; greatest width in posterior third of carapace. Shoulderlike swelling or ridge on posterodorsal third of both valves, most prominent on right valve. Lateral surface of both valves flattened anterior to shoulder. Surface smooth. Muscle scar median to anteromedian in position, round, composed of many small flecks. Marginal structures not observed.

Material.-More than 15 specimens from the McCann Hill Chert.

Measurements.-The holotype is $1.60 \mathrm{~mm}$ long, $1.00 \mathrm{~mm}$ high, and $0.80 \mathrm{~mm}$ wide (maximum width through shoulders).

Types.-Holotype, USNM 173819; paratypes, USNM 173820, 173821, 173822, 173823, 173824.

Discussion.-This species is questionably assigned to Bairdiohealdites because of its overlap and outline, especially the abrupt posterodorsal slope, and because of the distinct circular muscle scar, which was noted by McGill (1967, p. 1080) in the type species of the genus, $B$. rozhdestvenskayae. Bairdiohealdites? scapulatus, however, differs from other species referred to the genus in having a distinct posterodorsal shoulder. Although this character suggests a relationship to Condracypris Roth, 1929, Lundin (1968, p. 57-59) has noted that Condracypris has a duplicature, a structure that is lacking in $B$. ? scapulatus. Furthermore, species assigned to Condracypris characteristically have the greatest height anterior to the midlength, whereas in B.? scapulatus the greatest height is posterior to the midlength. Lundin $(1968$, p. 58) does not consider the elongate nodes of Condracypris binoda Roth, 1929, the type species of the genus, to be a generic character. It appears likely that these features may develop in other genera. The specific name of $B$. ? scapulatus refers to the posterodorsal shoulder characteristic of the species.

Occurrence.-USGS collections 6492-SD, 7032SD, 7033-SD, and 7037-SD from the McCann Hill Chert, Eagle (D-1) quadrangle, Alaska.

\section{Genus PRAEPILATINA Polenova, 1970 \\ Praepilatina sp. aff. P. praepilata sibirica Polenova, 1970 Plate 13, figures 5-7}

Description. - Lateral outline subsemicircular; dorsal margin nearly a semicircle; posterior margin steeply inclined; ventral margin straight to slightly concave; anterior margin sharply rounded. Left valve apparently overlaps right; posteroventral margin of left valve sharply rounded; posteroventral margin of right valve extended as small spine or angulation. Valves evenly convex in dorsal view. Surface smooth.

Material.-About 12 valves, many broken, from the McCann Hill Chert.

Measurements.-The two figured right valves are $0.75 \mathrm{~mm}$ long and $0.50 \mathrm{~mm}$ high, and $0.75 \mathrm{~mm}$ long and $0.50 \mathrm{~mm}$ high, respectively. The figured left valve is $1.10 \mathrm{~mm}$ long and $0.85 \mathrm{~mm}$ high.

Types.-Figured specimens, USNM 173825, 173826, 173827.

Discussion.-This form appears to be most similar to Praepilatina praepilata sibirica from the Lower Devonian of the Altai-Sayan region of Siberia as illustrated by Polenova (1970, pl. 24, figs. 3, 5 ) in the posteroventral projection of the right valve. Polenova $(1970$, p. 49$)$ distinguished $P$. praepilata sibirica from $P$. praepilata praepilata (Polenova, 1960), the type species, on the basis that the left valve showed more dorsal overlap in $P$. p. sibirica. Unfortunately, we have no carapaces and hence cannot determine the degree of overlap; however, figures of P. p. praepilata (Polenova, 1960, pl. 8, fig. 5; 1970 , pl. 24, fig. 2) show a rounded rather than acuminate posteroventral margin.

Occurrence.-USGS collections 7037-SD, 7038SD from the Eagle (D-1) quadrangle, Alaska. The holotype of $P$. p. sibirica is from the Lower Devonian upper Krekov beds of the Salair district in Siberia.

\section{Family BARYCHILINIDAE Ulrich, 1894 Genus BARYCHILINA Ulrich, 1891 Barychilina? sp. \\ Plate 14, figure 19}

Description. - Valve subrhomboidal; hingeline straight; overlap unknown. Deep elongate sulcus ex- 
tending from dorsal margin about one-third the distance to the ventral border. Shallow depression on anterodorsal corner; L1 broad, tumid. Surface of valves finely punctate with longitudinal ridges in posterior half, depressed areas between ridges finely reticulate.

Material.-One right valve from the Michelle Formation.

Measurements.-The figured specimen is $0.90 \mathrm{~mm}$ long and $0.50 \mathrm{~mm}$ high.

Types.-Figured specimen, GSC 29451.

Discussion.-This species is very similar to Barychilina? opisthorhysa (Kesling and Kilgore, 1952), but has a shorter sulcus and finer reticulate posterior ridges.

Occurrence.-Ludvigsen collection I-3 from the Michelle Formation, Hart River, Yukon Territory.

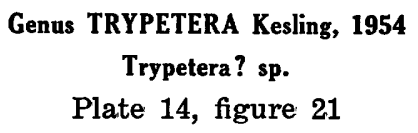

Description.-Dorsal margin straight; anterior margin smoothly curved; ventral margin gently curved; posterior margin broken. Deep round pit in anterodorsal part of right valve. Surface ornamentation consisting of large round punctae.

Material.-One broken right valve from the $\mathrm{Mi}$ chelle Formation.

Types.-Figured specimen, GSC 29447.

Discussion.-This form is known only from the anterior part of a right valve. The identification of this specimen is extremely questionable but appears plausible on the basis of the description of Trypetera by Kesling (1954, p. 178). No direct comparison with Trypetera barathrota Kesling, 1954, is attempted.

Occurrence.-Ludvigsen collection II-13 from the Michelle Formation, Blackstone River, Yukon Territory.

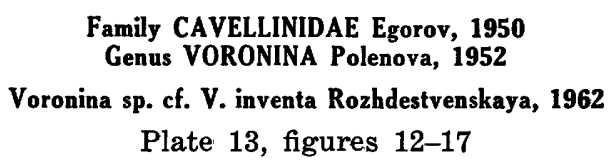

Description.-Lateral outline ovate; dorsal and ventral margins smoothly curved; anterior margin sharply curved; posterior margin bluntly subangulate. Carapace markedly asymmetrical; right valve larger than left, overlaps it all around. Greatest overlap dorsal; ventral overlap slightly less than dorsal overlap. Junction between lateral surface and marginal overlapping surface of right valve bluntly subangular; low keel may be developed at junction dorsally. Lateral surface of right valve flattened in end view; lateral surface of left valve smoothly convex. Dorsal and ventral margins of left valve nearly parallel; ends asymmetrically rounded, sharpest curve of anterior end ventral and sharpest curve of posterior end dorsal in position, so that lateral outline of left valve approximates a parallelogram. Interior of right valve with contact groove around free margins; hinge broken on only single valve (USNM. 173829) but apparently a simple sharp edge in right valve. Low swelling in anterodorsal half of right valve, anterior to which is possible oval muscle scar composed of large individual flecks. Exterior surface of valves smooth or finely punctate.

Material.-Two carapaces and a right valve from the McCann Hill Chert.

Measurements.-The figured carapace (pl. 13, figs. $12-14$ ) is $1.85 \mathrm{~mm}$ long, $1.35 \mathrm{~mm}$ high and $0.85 \mathrm{~mm}$ wide.

Types.-Figured specimens, USNM 173828 , $173829,173830$.

Discussion.-This form is very close to Voronina inventa Rozhdestvenskaya, 1962, but is apparently relatively shorter and higher. Rozhdestvenskaya (1962, p. 205) considered the right valve of $V$. inventa to be larger than the left, the reverse of the orientation suggested by Polenova (1952, p. 140) for $V$. voronensis Polenova, 1952, the type species of the genus. The specimens from Alaska appear to agree with Rozhdestvenskaya's orientation for $V$. inventa, as the presumed muscle scar is anterior in position and the greatest width is postmedian. Tolmachoff (1926, p. 36) described Ellesmeria ovata, the type species of his genus Ellesmeria, as having the right valve larger than the left, with greater overlap dorsally and ventrally than on the anterior and posterior ends; however, he also described $E$. ovata as having a shallow anterior sulcus on both valves, a feature which is not present in Voronina. Should the presence of a sulcus prove to be nondiagnostic for Ellesmeria, V. inventa Rozhdestvenskaya, 1962, and the Alaskan specimens might be considered to belong to Ellesmeria.

Both Polenova (1952, p. 141) and Rozhdestvenskaya $(1962$, p. 205) described dimorphism in Voronina, the tecnomorphs being flatter than the heteromorphs in dorsal view. The specimens from Alaska are considered to be heteromorphs by comparison with $V$. inventa; no tecnomorphic specimens have been found.

Occurrence.-USGS collections 6492-SD and 7032-SD, from the McCann Hill Chert, Eagle (D-1) quadrangle, Alaska.

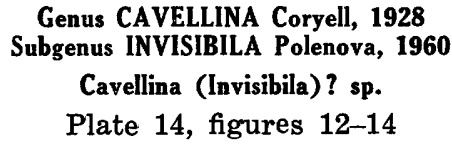

Description.-Lateral outline suboval ; dorsal margin gently curved; anterior and posterior ends evenly 
rounded ; ventral margin straight or slightly concave. Carapace narrow in dorsal view. Shell thin, shell surface smooth.

Material.-One sheared carapace and one right valve from the McCann Hill Chert.

Measurements.-The right valve of the carapace (USNM 173848) is $0.75 \mathrm{~mm}$ long and $0.40 \mathrm{~mm}$ high.

Types.-Figured specimens, USNM 173848, 173849.

Discussion.-The valves of the only carapace are sheared so that the character of the overlap and hingement cannot be determined. The general outline of the valves, however, resembles that of Cavellina (Invisibila) porrecta Polenova, 1960 (p. 33-34, pl. 5, fig. 5).

Occurrence.-USGS collection 7037-SD from the McCann Hill Chert, Eagle (D-1) quadrangle, Alaska.

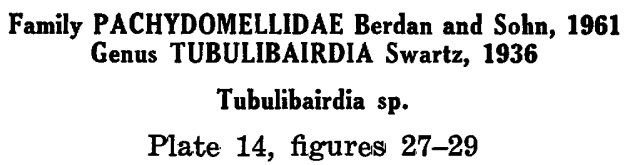

Plate 14, figures 27-29

Description.-Lateral outline of carapace suboval; dorsal margin broadly curved; anterior and posterior ends more closely curved; ventral margin gently curved to straight. Valves unequal; left valve overlaps right on free margins, narrowly on anterior and posterior ends and broadly ventrally, and overreaches right slightly dorsally. Hinge incised, half or more length of valve. Surface smooth.

Material.-One specimen from the Prongs Creek Formation; more than 15 specimens from the McCann Hill Chert.

Measurements.-The figured specimen from the McCann Hill Chert is $1.25 \mathrm{~mm}$ long, $0.75 \mathrm{~mm}$ high, and $0.80 \mathrm{~mm}$ wide.

Types.-Figured specimens, USNM 173831, GSC 29475.

Discussion.-Most of the specimens of Tubulibairdia from the McCann Hill Chert are noticeably poorly silicified in comparison to specimens of other genera in the same collections; some are steinkerns that show fillings of the characteristic tubules of Tubulibairdia. This poor preservation may be due to the coarsely porous character of the shell walls. The material at hand is not adequate to discriminate the species.

Occurrence.-USGS collections 6492-SD, 7032SD, 7033-SD, and 7037-SD from the McCann Hill Chert, Eagle (D-1) quadrangle, Alaska; Ludvigsen collection V-3, Prongs Creek Formation, Solo Creek, Yukon Territory.

\section{Pachydomellid indet. 1}

Plate 14, figures 24-26

Description.-Lateral and dorsal outlines of carapace subovate; anterior outline roughly heartshaped. Valves asymmetrical; left much larger than right, overreaching it dorsally and overlapping it ventrally and around ends. Hinge line deeply incised. Carapace very tumid; width greater than height, greatest width postmedian. Posterior of left valve with conspicuous compressed area; posterior of right valve also compressed, but not as much. Both anterior and posterior ends sharply rounded. Shell surface smooth or very faintly striatopunctate.

Material.-Two broken carapaces and nine left valves from the McCann Hill Chert.

Measurements.-The figured carapace is $0.60 \mathrm{~mm}$ long, $0.40 \mathrm{~mm}$ high, and $0.45 \mathrm{~mm}$ wide.

Types.-Figured specimens, USNM 173832, 173833.

Discussion.-The pronounced asymmetry, incised hinge line, and thick shell suggest that these specimens belong in the Pachydomellidae, although the preservation is such that the characteristic tubules of that family cannot be seen. The compressed posterior of both valves and the tumidity are characteristic of the genus Newsomites Morris and Hill, 1952, which Lundin and Newton $(1970$, p. 33, 34) consider similar to the pachydomellids although retaining it in the Bairdiidae pending further study. However, species assigned to Newsomites, such as N. pertumidus Morris and Hill, 1952, N. profusus Lundin and Newton, 1970, and N. notabilis (Polenova, 1955) have the greatest thickness median rather than postmedian as in the pachydomellids and the specimens from the McCann Hill Chert.

Occurrence.-USGS collections 6492-SD, 7032SD, 7037-SD, and 7038-SD from the McCann Hill Chert, Eagle (D-1) quadrangle, Alaska.

\section{Pachydomellid indet. 2 \\ Plate 14, figure 23}

Description.-Lateral outline suboval; dorsum curved; anterior end evenly curved; ventral outline straight to gently convex; posterior end more acute than anterior. Hinge straight, incised. Surface covered with spines, which are longest at ventral edge of lateral surface and shortest on flattened venter. Shell thick, apparently tubulous.

Material.-Two left valves from the McCann Hill Chert.

Measurements.-The figured specimen is $0.55 \mathrm{~mm}$ long and $0.30 \mathrm{~mm}$ high.

Types.-Figured specimen, USNM 173846.

Discussion.-These specimens resemble the inter- 
nal molds of Tubulibairdia in which the shell is dissolved and the traces of the filled tubules appear as spines. However, in these valves the shell is preserved and appears to be tubulous, although the silification obscures the structure. They may represent a Tubulibairdia-like form in which the setae which were presumably in the tubules became sheathed in spines, although the preservation is such that the spines do not appear to be hollow.

Occurrence.-USGS collection 7037-SD from the McCann Hill Chert, Eagle (D-1) quadrangle, Alaska.

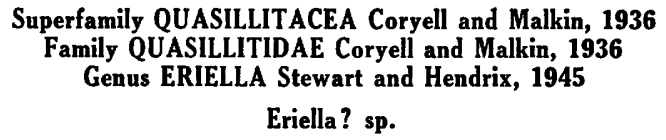

Plate 14, figures 1, 2

Description.-Right valve subovate in lateral outline; greatest height median; anterior and posterior margins equally rounded. Hinge long, nearly onethird the greatest length, situated near median and incised below dorsal shoulder. Surface coarsely reticulate, reticulae in concentric rows about a central reticulate area near midvalve; central pit, if present, the same size as surrounding reticulae.

Material.-One right valve from the Michelle Formation, four specimens from the McCann Hill Chert.

Measurements.-The figured specimen from the Michelle Formation is $0.50 \mathrm{~mm}$ long and $0.30 \mathrm{~mm}$ high.

Types.-Figured specimens, GSC 29452, USNM 173834.

Discussion.-This species is smaller, more ovate and more coarsely reticulate than the type species, Eriella robusta Stewart and Hendrix, 1945, from the "Plum Brook Formation" of Ohio. The specimens from the McCann Hill Chert are somewhat more finely reticulate than the specimen from the $\mathrm{Mi}$ chelle, and may not be conspecific. The figured right valve from the McCann Hill Chert has a small posteroventral spine as described for Eriella.

Occurrence.-Ludvigsen collection I-3 from the Michelle Formation, Hart River, Yukon Territory; USGS collection 7037-SD, McCann Hill Chert, Eagle (D-1) quadrangle, Alaska.

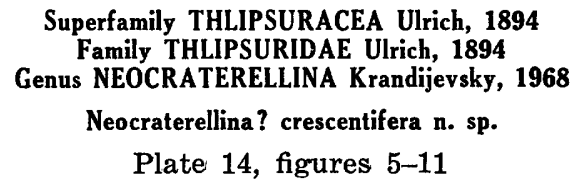

Healdia sp., Berdan in Churkin and Brabb, 1968, table 1, pl. 4, fig. 1. [Imprint 1967.]

Description. - Lateral outline ovate; dorsum smoothly curved; anterior margin sharply rounded; ventral margin nearly straight to slightly convex; posterior margin smoothly curved. Left valve larger than right, overreaching it dorsally and overlapping it distinctly on posterior and ventral margins, overlapping it narrowly on anterior margin. Dorsal outline subovate; hinge line narrowly incised. Greatest length median; greatest height slightly posteromedian; greatest width posteromedian. Left valve with crescentic groove subparallel to posterior margin, extending from posterodorsal third of valve to posteroventral quarter. Right valve with similar, shorter groove in posterior third which does not extend as far dorsally as groove in left valve. Shell surface otherwise smooth. Muscle scar apparently oval, situated on low ridge or swelling which is not seen on exterior of valve. Hinge short, straight; details of hingement not known. Contact groove present around free margins of left valve, apparently interrupted ventrally.

Material.-Eight carapaces and five single valves from the McCann Hill Chert.

Measurements.-The holotype is $0.75 \mathrm{~mm}$ long, $0.45 \mathrm{~mm}$ high, and $0.40 \mathrm{~mm}$ wide.

Types.-Holotype, USNM 173835; paratypes, USNM 170336, 173836, 173837, 173838.

Discussion.-This species was originally assigned to Healdia because of the crescentic posterior groove; however, it lacks the characteristic posterodorsal flattening of true Healdia. Further study of the muscle scar and the character of the groove suggests that Neocraterellina? crescentifera is a thlipsurid. Krandijevsky $(1968$, p. 72$)$ proposed the genus Neocraterellina, with Craterellina oblonga Ulrich and Bassler, 1913, as the type species, for thlipsurids with one curved or horseshoe-shaped or round closed furrow. Thlipsurella orthoclefta Swartz, 1932, was included in this genus by Krandijevsky (1968, p. 72). This species is comparable to N.? crescentifera in having a single posterior groove, but the groove of $N$. orthoclefta is straight rather than crescentic as in N.? crescentifera. The holotype of $N$. orthoclefta (USNM 86504) from the Shriver Chert in Pennsylvania appears to have a more strongly curved dorsum than illustrated by Swartz (1932, pl. 11, fig. 3a) and thus is closer to N.? crescentifera than is shown by the figures of both species.

Occurrence.-USGS collections 6492-SD, 7032SD, 7033-SD, and 7037-SD from the McCann Hill Chert, Eagle (D-1) quadrangle, Alaska.

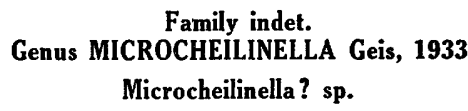

Description.-Carapace small, tumid, subovate in 
lateral view. Left valve overlapping right all around except dorsally. Hinge half greatest length, occupying middorsal area, incised between shoulders of both valves. Greatest height and length median; greatest width in posterior third. Surface smooth.

Material.-Two specimens from the Prongs Creek Formation.

Measurements.-The figured specimens are 0.60 $\mathrm{mm}$ long, $0.34 \mathrm{~mm}$ high, and $0.35 \mathrm{~mm}$ wide.

Types.-Figured specimens, GSC 29514, 29515.

Discussion.-This species is not readily distinguishable from numerous other small ovate smooth ostracodes of microcheilinellid type. The hinge of this species may be more incised than that of many other species, but this could be a matter of preservation. Until a complete revision of this genus is attempted, it is felt that a specific designation is unnecessary.

Occurrence.-Ludvigsen collection V-3 from the Prongs Creek Formation, Solo Creek, Yukon Territory.

\section{Ostracode indet. 1}

Plate 14, figure 20

Description.-Hinge line straight; prominent median sulcus in anterior half of valve; sulcus extends nearly to midvalve. Presulcal node ovate, indistinct; slight indication of $\mathrm{S} 1$ in anterodorsal corner of valve. Lateral outline subovate. Surface slightly papillose with faint posterior lineation. Anteroventral flange or spur projecting from right valve margin in position of spur on Hanaites. Pronounced tubercle present in posterodorsal quarter of valve. No other marginal structure observed.

Material.-Two incomplete specimens from the Michelle Formation.

Measurements.-The incomplete figured specimen is $0.90 \mathrm{~mm}$ long and $0.55 \mathrm{~mm}$ high.

Types.-Figured specimen, GSC 29511.

Discussion.-The specimens are crushed and too poorly preserved for more exact identification. Superficially they appear to have some characteristics of Hanaites but apparently are not reticulate.

Occurrence.-Ludvigsen collection I-3 from the Michelle Formation, Hart River, Yukon Territory.

\section{Ostracode indet. 2}

\section{Plate 14, figure 22}

Description.-Lateral outline semielliptical, amplete to postplete. Hinge line straight; anterior margin smoothly rounded; ventral margin gently curved, swinging up into more acutely curved posterior margin. S1 shallow and poorly defined; S2 wide, somewhat deeper than S1, extending about half height of valve; weak S3 or hemisulcus in posterior quarter of valve. L1 broad, smoothly arched; L2 small, ovate, set below hinge line; L3 broad, slightly humped above hinge line; L4 smooth, sloping to posterior margin. Anterior end of valve with poorly defined velar bend which extends posteriorly to beneath L3 but merges with surface anterior to small posteroventral spine. Small anterodorsal spine above S2. Shell surface apparently smooth to very finely granulose.

Material.-One left valve from the McCann Hill Chert.

Measurements.-The figured specimen is $1.30 \mathrm{~mm}$ long and $0.75 \mathrm{~mm}$ high.

Types.-Figured specimen, USNM 173839.

Discussion.-The anterior position of the weak velar bend, the small posteroventral spine and the humping of L3 above the hinge line suggest that this specimen may be an aberrant hollinid, but the weak sulcation and poorly developed velar structures are atypical of the Hollinacea.

Occurrence.-USGS collection 6492-SD from the McCann Hill Chert, Eagle (D-1) quadrangle, Alaska.

\section{Ostracode indet. 3}

Plate 14, figures 15, 16

Description.-Carapace small, tumid, subovatetriangular in lateral view. Right valve overlapping left all around except dorsally. Hinge half greatest length, occupying middorsal area, incised between shoulders of both valves. Valves with narrow anterior and posteroventrally drawn-out flanges; more pronounced on right valve. Greatest height and width median; greatest length in ventral half. Surface somewhat granular, possibly with internal tubules.

Material.-Two specimens from the Prongs Creek Formation.

Measurements.-The figured specimens are 0.60 $\mathrm{mm}$ long, $0.35 \mathrm{~mm}$ high, and $0.40 \mathrm{~mm}$ wide.

Types.-Figured specimens, GSC 29516, GSC 29517.

Discussion.-If these specimens are interpreted correctly, they possess right-over-left overlap. A reversal of overlap may exist with some pachydomellid genus, but this cannot be substantiated with the material at hand. These specimens are similar to the specimens from the McCann Hill Chert previously described as "pachydomellid, indet. 1" but differ in having the greatest thickness median rather than posterior and in having both anterior and posterior flanges.

Occurrence.-Ludvigsen collection V-3 from the Prongs Creek Formation, Solo Creek, Yukon Territory. 


\section{REFERENCES CITED}

Adamczak, Franciszek, 1967, Morphology of two Silurian metacope ostracodes from Gotland: Geol. Fören. Stockholm Förh., v. 88, pt. 4, no. 527, p. 462-475, 11 figs. 1968, Palaeocopa and Platycopa (Ostracoda) from Middle Devonian rocks in the Holy Cross Mountains, Poland: Stockholm Univ. Acta, Stockholm Contr. Geology, v. 17, 109 p., 46 pls.

Bassler, R. S., 1941, Ostracoda from the Devonian (Onondaga) chert of west Tennessee: Washington Acad. Sci. Jour., v. 31, no. 1, p. 21-27, 1 pl.

Becker, Gerhard, 1968a, Geschlechtsdimorphismus bei Ostracoden, II : Natur und Mus., v. 98, no. 3, p. 119-132.

1968b, Zur Morphologie und Systematik der Palaeocopida-Gattung Nodella Zaspelova und Aechminella Harlton: Senckenbergiana Lethaea, v. 49 , no. 5/6, p. 547-563, 1 pl.

Berdan, J. M., 1960, Revision of the ostracode family Beecherellidae and redescription of Ulrich's types of Beecherella: Jour. Paleontology, v. 34, no. 3, p. 467$478,1 \mathrm{pl}$.

1971, Some ostracodes from the Schoharie Formation (Lower Devonian) of New York, in Dutro, J. T., Jr., ed., Paleozoic Perspectives: A Paleontological Tribute to G. Arthur Cooper: Smithsonian Contr. Paleobiology, no. 3, p. 161-174, 1 pl.

Bless, M. J. M., and Jordan, Hanspeter, 1971, Classification of palaeocopid ostracodes belonging to the families Ctenoloculinidae, Hollinidae and Hollinellidae, in Oertli, H. J., ed., Colloque sur la paleoecologie des OstracodesColloquium on the paleoecology of Ostracodes, Pau, 20 27, VII, 1970: Centre Recherches Pau Bull., v. 5 supp., p. 869-890.

1972, Ostracodes of the family Hollinellidae: [Netherlands] Rijks Geol. Dienst, ser. C-V-3, no. 1, 154 p., 35 pls.

Blumenstengel, Horst, 1965, Zur Taxionomie und Biostratigraphie verkieselter Ostracoden aus dem Thüringer Oberdevon: Freiberger Forschungshefte, C 183, 127 p., 29 pls.

- 1970, Oberdevonische Ostracoden aus der Bohrung Mandelholz 18/56 (Harz, Elbingeröder Komplex): Freiberger Forschungshefte, C 256, p. 7-34, 5 pls.

Bouček, BedFich, 1936, Die Ostracoden des böhmischen Ludlows (Stufe e $\beta$ ): Neues Jahrb. Mineralogie, Geologie u. Paläontologie, Beil.-Bd. 76, Abt. B, no. 1, p. 31-98, 5 pls.

- 1967, Significance of dacryoconarid tentaculites and graptolites for the stratigraphy and palaeogeography of the Devonian System, in Oswald, D. H., ed., International Symposium on the Devonian System, Calgary, 1967: Calgary, Alberta Soc. Petroleum Geologists, v. 2, p. 1275-1281 [1968].

Boucot, A. J., Johnson, J. G. and Talent, J. A., 1969, Early Devonian brachiopod zoogeography: Geol. Soc. America, Spec. Paper 119, $113 \mathrm{p}$.

Brabb, E. E., and Churkin, Michael, Jr., 1965, Preliminary geologic map of the Eagle D-1 quadrangle, east-central Alaska: U.S. Geol. Survey open-file report, 2 sheets, scale $1: 63,360$.

Churkin, Michael, Jr., and Brabb, E. E., 1965, Ordovician, Silurian, and Devonian biostratigraphy of east-central Alaska: Am. Assoc. Petroleum Geologists Bull., v. 49, no. 2, p. 172-185.

1967, Devonian rocks of the Yukon-Porcupine Rivers area and their tectonic relation to other Devonian sequences in Alaska, in Oswald, D. H., ed., International Symposium on the Devonian System, Calgary, 1967: Calgary, Alberta Soc. Petroleum Geologists, v. 2, p. 227-258 [1968].

Churkin, Michael, Jr., and Carter, Claire, 1970, Devonian tentaculitids of east-central Alaska; systematics and biostratigraphic significance: Jour. Paleontology, v. 44, no. 1, p. 51-67, 3 pls.

Copeland, M. J., 1962, Ostracoda from the Lower Devonian Dalhousie beds, northern New Brunswick: Canada Geol. Survey Bull. 91, p. 18-51, 6 pls.

Fåhraeus, L. E., 1971, Lower Devonian conodonts from the Michelle and Prongs Creek Formations, Yukon Territory: Jour. Paleontology, v. 45, no. 4, p. 665-683, 2 pls.

Groos, Helga, and Jahnke, Hans, 1970, Bemerkungen zu unterdevonischen Beyrichien (Ostracoda) aus dem Rheinischen Schiefergebirge und dem Harz: Göttinger Arb. Geologie Paläontologie, v. 5, p. 37-46, 1 pl.

Harris, R. W., 1957, Ostracoda of the Simpson Group of Oklahoma: Oklahoma Geol. Survey Bull. 75, 333 p., 10 pls.

Henningsmoen, Gunnar, 1954, Silurian ostracods from the Oslo region, Norway; 1, Beyrichiacea. With a revision of the Beyrichiidae: Norsk Geol. Tidsskr., v. 34, no. 1, p. 15-71, 8 pls.

1965, On certain features of palaeocope ostracodes: Geol. Fören. Stockholm Förh., v. 86, p. 329-394.

House, M. R., and Pedder, A. E. H., 1963, Devonian goniatites and stratigraphical correlations in western Canada: Palaeontology, v. 6, pt. 3, p. 491-539, 8 pls.

Jaanusson, Valdar, and Martinsson, Anders, 1956, Two hollinid ostracodes from the Silurian Mulde marl of Gotland: Uppsala Univ. Geol. Inst. Bull., v. 36, pt. 4, p. $401-409,1 \mathrm{pl}$.

Jaeger, Hermann, 1970, Remarks on the stratigraphy and morphology of Praguian and probably younger monograptids: Lethaia, v. 3, no. 2, p. 173-182.

Johnson, J. G., and Lane, N. G., 1969, Two new Devonian crinoids from central Nevada: Jour. Paleontology, v. 43 , no. 1 , p. $69-73,1$ pl.

Jordan, Hanspeter, 1964, Zur Taxionomie und Biostratigraphie der Ostracoden des hochsten Silur und Unterdevon Mitteleuropas: Freiberger Forschungshefte, C 170,146 p., 29 pls.

Kesling, R. V., 1952, Ostracods of the families Leperditellidae, Primitiidae, Drepanellidae, Aechminidae and Kirkbyidae from the Middle Devonian Bell Shale of Michigan: Michigan Univ. Mus. Paleontology Contr., v. 10, no. 2, p. 21-44, 5 pls.

1954, Ostracods from the Middle Devonian Dundee Limestone in northwestern Ohio: Michigan Univ. Mus. Paleontology Contr., v. 11, no. 8, p. 167-186, 3 pls.

Kesling, R. V., and McMillan, G. W., 1951, Ostracods of the family Hollinidae from the Bell Shale of Michigan: Michigan Univ. Mus. Paleontology Contr., v. 9, no. 2, p. 45-81, 7 pls.

Kesling, R. V., and Peterson, R. M., 1958, Middle Devonian hollinid ostracods from the Falls of the Ohio: Micropaleontology, v. 4, no. 2, p. 129-148, 2 pls.

Kesling, R. V., and Rogers, K. J., 1957, Size, lobation, velate structures, and ornamentation in some beyrichiid 
ostracods: Jour. Paleontology, v. 31, no. 5, p. 997-1009, 3 pls.

Kesling, R. V., and Tabor, N. R., 1953, Ostracods of the family Hollinidae from the Genshaw formation of Michigan: Michigan Univ. Mus. Paleontology Contr., v. 10, no. 5, p. 83-100.

Klapper, Gilbert, and others, 1971, North American Devonian conodont biostratigraphy, in Sweet, W. C., and Bergström, S. M., eds., Symposium on Conodont Biostratigraphy: Geol. Soc. America Mem. 127, p. 285-316.

Krandijevsky, V. S., 1968, Reviziya semeistva Thlipsuridae Ulrich (Ostracoda), in Paleontologiya i stratigrafiya nizhnegopaleozoya Vol'no-Podolii: Kiev, Akad. Nauk Ukrain. SSR Inst. Geol. Nauk, p. 63-79, 1 pl.

Lenz, A. C., 1967, Upper Silurian and Lower Devonian biostratigraphy, Royal Creek, Yukon Territory, Canada, in Oswald, D. H., ed., International Symposium on the Devonian System, Calgary, 1967: Calgary, Alberta Soc. Petroleum Geologists, v. 2, p. 587-599 [1968].

- 1972, Ordovician to Devonian history of northern Yukon and adjacent District of Mackenzie: Bull. Canadian Petroleum Geology, v. 20, no. 2, p. 321-361.

Ludvigsen, Rolf, 1970, Age and fauna of the Michelle Formation, northern Yukon Territory: Bull. Canadian Petroleum Geology, v. 18, no. 3, p. 407-429, 4 pls.

- 1972, Late Early Devonian dacryoconarid tentaculites, northern Yukon Territory: Canadian Jour. Earth Sci., v. 9, no. 3, p. 297-318, 3 pls.

Lundin, R. F., 1968, Ostracodes of the Haragan Formation (Devonian) in Oklahoma: Oklahoma Geol. Survey Bull. 116,121 p., 21 pls.

Lundin, R. F., and Newton, G. D., 1970, Ostracoda and the Silurian stratigraphy of northwestern Alabama: Alabama Geol. Survey Bull. 95, 64 p., 7 pls.

Martinsson, Anders, 1960, Ostracods, in Boucot, A. J. and others, A Late Silurian fauna from the Sutherland River Formation, Devon Island, Canadian Arctic Archipelago: Canada Geol. Survey Bull. 65, 51 p., 1 pl.

1962, Ostracodes of the family Beyrichiidae from the Silurian of Gotland: Uppsala Univ. Geol. Inst. Bull., v. 41, 369 p.

McGill, Peter, 1967, Comparison of a middle Givetian ostracode fauna from Carcajou Ridge, Northwest Territories, Canada, with similar faunas from Europe, in Oswald, D. H., ed., International Symposium on the Devonian System, Calgary, 1967: Calgary, Alberta Soc. Petroleum Geologists, v. 2, p. 1069-1085, 4 pls. [1968].

Moore, R. C., ed., 1961, Treatise on invertebrate paleontology -Part Q, Arthropoda 3: New York and Lawrence, Kans., Geol. Soc. America and Univ. Kansas Press, $442 \mathrm{p}$.

Morris, R. W., and Hill, B. L., Jr., 1951, Shidelerites, a new Silurian ostracode genus: Jour. Paleontology, v. 25, no. 5 , p. 698-699.

1952, New Ostracoda from the Middle Silurian Newsom Shale of Tennessee: Bulls. Am. Paleontology, v. 34 , no. 142, 22 p., 2 pls.

Norris, A. W., 1967a, Descriptions of Devonian sections in northern Yukon Territory and northwestern District of Mackenzie: Canada Geol. Survey Paper 66-39, 298 p.

- 1967b, Devonian of northern Yukon Territory and adjacent District of Mackenzie, in Oswald, D. H., ed., International Symposium on the Devonian System, Cal- gary, 1967: Calgary, Alberta Soc. Petroleum Geologists, v. 1 , p. $753-780$ [1968].

1968, Reconnaissance Devonian stratigraphy of northern Yukon Territory and northwestern District of Mackenzie: Canada Geol. Survey Paper 67-53, 287 p.

Ormiston, A. R., 1969, The trilobite Koneprusia in the Lower Devonian of Alaska: Jour. Paleontology, v. 43, no. 5, p. 1210-1212.

- 1971, Lower Devonian trilobites from the Michelle Formation, Yukon Territory: Canada Geol. Survey Bull. 192, p. 27-42, 2 pls.

Pokorný, Vladimír, 1950, Skořepatci strednodevonských “červených vápenců korálových” z Čelechovic [The ostracods of the Middle Devonian Red Coral Limestones of Čelechovice]: Czechoslovakia, Státní Geol. Ústav, Sborník, v. 17, Pal., p. 513-632, 5 pls.

Polenova, E. N., 1952, Ostrakody verknei chasti Zhivetskogo Yarusa Russkoi platformy, in Mikrofauna SSSR, Sbornik V: Vses. Neft. Nauchno-Issled. Geol.-Razved. Inst. (VNIGRI), Trudy, new ser., no. 60 , p. 65-156, 15 pls.

- 1960, Devonskie ostrakody Kuznetskogo basseina i Minusinskoi kotloviny: Vses. Neft. Nauchno-Issled. Geol.-Razved. Inst. (VNIGRI), Trudy, no. 152, 139 p., $13 \mathrm{pls}$.

— 1968, Ostrakody nizhnego Devona Salaira: Akad. Nauk SSSR Sibirsk. Otdeleniye Inst. Geologii i Geofiziki, 154 p., 26 pls.

- 1970, Ostrakody pozdnego Silura i rannego Devona Altaye-Sayanskoi oblasti: Akad. Nauk SSSR Sibirsk. Otdeleniye Inst. Geologii i Geofiziki Trudy, v. 127, 104 p., 34 pls.

Rozhdestvenskaya, A. A., 1959, Ostrakody terrigennoy tolshchi Devona zapadnoi Bashkirii i ikh stratigraficheskoe znachenie, in Chibrikova, E. V., and Rozhdestvenskaya, A. A., eds., Materialy po paleontologii i stratigrafii Devonskikh i bolee drevnikh otlozhenii Bashkirii: Moscow, Akad. Nauk SSSR, Bashkirskii Filial, p. 117245,30 pls.

- 1962, Srednidevonskie ostracody zapadnogo sklona Yuzhnogo Urala, Predural'skogo progiba i platformennoi chasti Bashkirii, in Tyazheva, A. P., Rozhdestvenskaya, A. A., and Chibrikova, E. V., Brakhiopody, ostrakody i spory srednego i verkhnego Devona Bashkirii: Moscow, Akad. Nauk SSSR, Bashkirskii Filial, Gorno-Geologicheskii Inst., p. 169-349, 35 pls.

Sohn, I. G., 1960, Paleozoic species of Bairdia and related genera: U.S. Geol. Survey Prof. Paper 330-A, 105 p., 6 pls. [1961].

- 1961, Aechminella, Amphissites, Kirkbyella, and related genera: U.S. Geol. Survey Prof. Paper 330-B, p. $107-160,6$ pls. [1962].

Stearn, C. W., and Mehrota, P. N., 1970, Lower and Middle Devonian stromatoporoids from northwestern Canada: Canada Geol. Survey Paper 70-13, 43 p.

Stoltidis, Ilias, 1971, Ostrakoden aus dem Unterdevon des Bergischen Landes (Rheinisches Schiefergebirge) : Decheniana, v. 124 , no. 1 , p. 1-38, 5 pls.

Stover, L. E., 1956, Ostracoda from the Windom Shale (Hamilton) of western New York: Jour. Paleontology, v. 30 , no. 5 , p. $1092-1142,8$ pls.

Swain, F. M., 1953, Ostracoda from the Camden Chert, western Tennessee: Jour. Paleontology, v. 27, no. 2, p. 257-284, 3 pls. 
Swartz, F. M., 1932, Revision of the ostracode family Thlipsuridae, with descriptions of new species from the Lower Devonian of Pennsylvania: Jour. Paleontology, v. 6 , no. 1 , p. 36-58, 2 pls.

1933, Dimorphism and orientation in ostracodes of the family Kloedenellidae from the Silurian of Pennsylvania: Jour. Paleontology, v. 7, no. 3, p. 231-260, 3 pls.

1969, Ordovician ostracode Aparchites whiteavesi Jones (1889), and problems of relationships: Jour. Paleontology, v. 43, no. 5, p. 1237-1244, 1 pl.

Tolmachoff, I. P., 1926, On the fossil faunas from Per Schei's Series D from Ellesmere Land with exception of brachiopods, corals, and cephalopods: Second Norwegian Arctic Expedition in the Fram, 1898-1902, Oslo, Rept. 38,106 p., 8 pls.

Triebel, Erich, 1961, Asymmetrie der Klappen und Ausrichtung des Gehäuses bei der Ostracoden-Gattung Shidelerites: Senckenbergiana Lethaea, v. 42 , no. 5/6, p. 347-351, 1 pl.

Ulrich, E. O., 1891, New and little known American Paleo- zoic Ostracoda: Cincinnati Soc. Nat. History. Jour., v. 13 , no. 4 , p. $173-211,8$ pls.

Ulrich, E. O., and Bassler, R. S., 1923, Systematic paleontology of Silurian deposits; Ostracoda: Maryland Geol. Survey, Silurian [Volume], p. 500-704, 30 pls.

Warthin, A. S., Jr., 1937, Beyrichiacea in Type invertebrate fossils of North America (Devonian): Wagner Free Inst. Sci. Unit 9-A, 106 cards.

Weyant, Marcel, 1968, Ostracodes du genre Poloniella Gürich au Dévonien Moyen de l'Ile Ellesmere (Archipel Arctique Canadien) : Rev. Micropaléontologie, v. 11, no. 2, p. 99-110, 2 pls.

Zagora, Karl, 1968, Ostracoden aus dem Grenzbereich UnterMitteldevon von Ostthüringen: Geologie, Beihefte, v. 17, no. 62,64 p., 13 pls.

Zaspelova, V. S., 1959, Ostrakody i ikh znachenie dlya stratigrafii Devona severo-zapadn'ikh oblastei Russkoi platformy, in Sklykova, T. I., ed., Mikrofauna SSSR. Sbornik X, Ostrakody i foraminifery Russkoi platformy i srednei Azii: Vses. Neft. Nauchno-Issled. Geol.-Razved. Inst. (VNIGRI) Trudy, no. 136, p. 6-97, 17 pls. 



\section{INDEX}

\section{A}

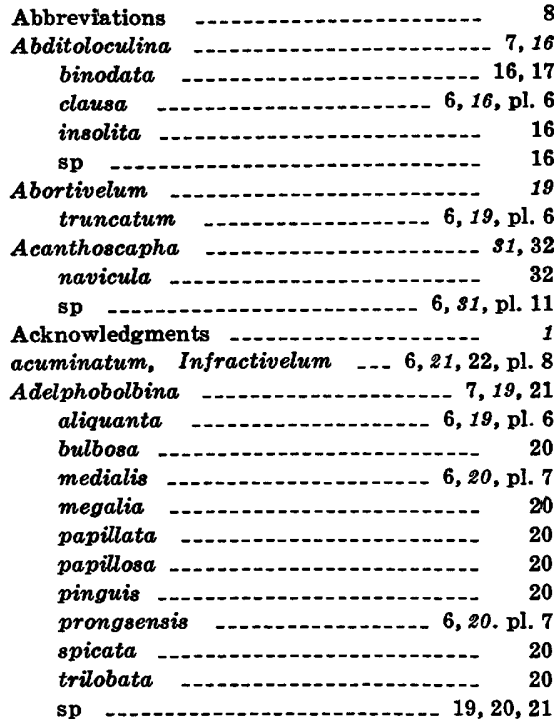
Ages of formations

Alaskabolbina -......... 14

bilineata

nodilineata _............ 6,14, 15, pl. 5

unilineata _............. 6, 14, 15, pl. 5

sp _...

alatus, Pseudocyproides -.... 33

aliquanta, Adelphobolbina _....... 6, 19, pl. 6

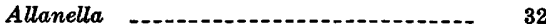

AltaiSayan region, Siberia, U.S.S.R. -- 36

antespinosa, Hollinella ................ 18, 19

Aparchites 27,28 auriculiferus _.......... 6, 7, 28, pl. 10 chuchlensis -.--1.-- 29

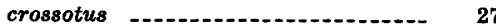

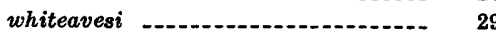

Aparchitidae

Apatobolbina -........ 14

arctigena, Beyrichia (Beyrichia) -...- 10

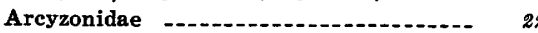

argutula, Knoxites ................. 15

Ogilvites -

auriculiferus, Aparchites

\section{B}

Bairdia

$30,31,32$

dejecta

emaciata

leguminoides _.......... 6, $\$ 0,31, \mathrm{pl} .11$

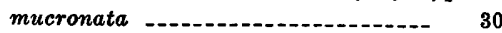

navicula

transversocostata _............. 31

Bairdiidae - 30,32

Bairdiocyprididae -

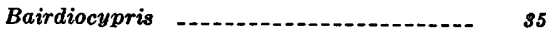
cordiformis _........... 6, 7, $35, \mathrm{pl} .12$ sp
[Italic page numbers indicate major reference]

Bairdiohealdites _. rozhdestvenskayae _._._._._._... 36 scapulatus _................ 6, 36, pl. 12 Bairdiolites -...... 31 sohni _.................. 6, 31, pl. 11 barathrota, Trypetera Barychilina opisthorhysa _....... 37 sp

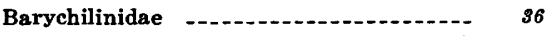
Bashkiria, U.S.S.R. _....... 7, 28, 29, 35

Beecherella carinata sp

Beecherellidae _.

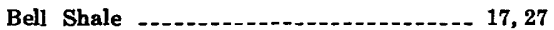
Berounella -...- 34 minuta Berounellidae Beyrichia -... 10,12 (Beyrichia) _...................... 70 arctigena brabbi sp. A -... 10 sp. B 10

(Scabribeyrichia) - 7,10 churkini _._._-_._.- 6, 10, 3 foliosa sp -

(Beyrichia) arctigena, Beyrichia -..- 10 brabbi, Beyrichia -_._-_ 6, 10, pl. 2 sp. A, Beyrichia _......... 10 sp. B, Beyrichia 10

Beyrichiinae - -

Bibliography -

Bicornina -......

sp - 6, s4, pl. 12 bicornis, Ogilvites _.......... 6, 15, pl. 6 bilineata, Alaskabolbina -....- 6, 14, 15, pl. 5 binoda, Condracypris _..... 36 binodata, Abolitoloculina _._.......... 16, 17 Biya beds, Bashkiria, U.S.S.R. Blackstone River blackstonensis, Kuresaaria _._._. $6,35, \mathrm{pl} .12$ Blue Fiord Formation _......... 5, 8, 30 Bohemia - borealis, Treposella brabbi, Beyrichia (Beyrichia) _...6, 10, pl. 2 brevis, Hanites -......- 6, 24, 25, 26, pl. 9 bulbosa, Adelphobolbina _......... 20 Bythocypris sp -

\section{C}

Camden Chert camdenensis, Camdenidea Camdenidea -.... - . camdenesis -........ 33 sp Canadian Arctic Archipelago ........ carinata, Beecherella _............ 33 caurina, Tricornina Cavellina -....... (Invisibila) _... porrecta -...- 38 sp Beyrichiidae -
Page

Celechovites -

Chironiptrum -.-.....

limitaris

reticularis

sp -

chuchlensis, Aparchites churkini, Beyrichia

(Scabribeyrichia) _... 6, 10, pl. 3

circulata, Libumella _._..... 6. 28, pl. 10

clausa, Abditoloculina

Clintiella -.-

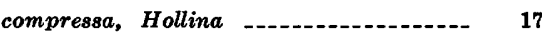

Condracypris -

binoda

Contact, McCann Hill Chert-Road

River Formation -..... 2

Michelle and Road River Formations 2

Nation River Formation-McCann Hill Chert -...-

Ogilvie and Michelle Formations_- 3

Prongs Creek and Road River Formations _...... 3

cordiformis, Bairdiocypris -

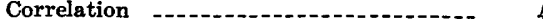

intercontinental

Craspedobolbininae

Craterellina oblonga

crescentifera, Neocraterellina _..- 7, 39, pl. 14

crossotus, Aparchites

Subarctichites

Ctenoloculinidae -

Ctenoloculininae

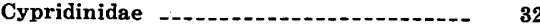

Cystomatochilina _._. 14

D

dalhousiensis, Eukloedenella dejecta, Bairdia _.. 6, so, pl. 11

Devon Island, Canada -.... 5 discoides, Libumella

\section{$\mathrm{E}$}

Eag!e (D-1) quadrangle, Alaska _..... 3, 8 eifeliensis, Obotritia Ellesmere Island _.............. 8, 20, 30 Ellesmeria - _._-_._._. 37 ovata -

emaciata, Bairdia -.-_- 30 Eobeyrichia -..... 11 Eriella -.robusta - . sp Eukloedenella

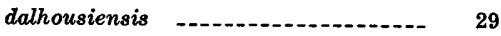
recta soloensis _..._._._._._.... 6, 29, pl. 11 sulcifrons -........ 29 umbilicata sp -

Eurekaspirifer pinyonensis Zone .....- 5 Eurychilina mirabilis ....... 24, 25 


\section{F}

Page

Falls of the Ohio River

Falsipollex

multispinosus $\ldots \ldots \ldots . . .6,17, \mathrm{pl} .7$

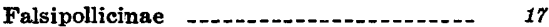

Flaccivelum -

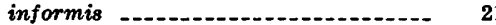

teleutaea -..-...-.... 21 sp foliosa, Beyrichia (Scabribeyrichia) -.- 11

Fossil collections -...-........-.....-3, 5, 8 (Framella), Poloniella -...-..--..-.- so scheii, Poloniella _......... 6, 8, so, pl. 11

\section{G}

Garniella

Gasterocoma bicaula -

Genshaw Formation ....-_-_-17, 20

givetiana, Halliella (Hanaites) -.....--. 24

Hanaites --.-.-.-.-.-.-.-.-.-.-. 25

gotlandica, Kuresaaria --.---.--_.--- 35

granosa, Parabolbina --.--.-_- 17

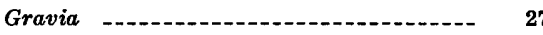

Guerichina strangulata Zone _.......- 5

\section{$\mathrm{H}$}

Halliella (Hanaites) givetiana -........... 24

Hanaites

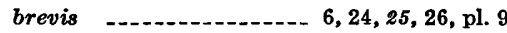
givetiana -.....-............ 25 linearis _........... 6, 24, 25, 26, pl. 9 platus spinosus -........ 6, 24, 25, pl. 9 sp. A $-1-10$

sp. B -.........- 25

(Hanaites) givetiana, Halliella --.--- 24

Hart River -..-.................. 1, 2, 3, 8

hartleyi, Mesomphalus -..... 9

Harz region, Germany -............ 5

Healdia -

sp --- 39

Heteromorph, defined -................ 18

Hillard Peak -

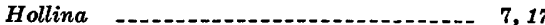

compressa - -

insolens - -

pyxidata -...-...-..-17

sp -

Hollinella

antespinosa

ludvigseni -....- 6, 18, pl. 7

paucituberculata _.............. 6, 18, pl. 7

plauta -........................ 18

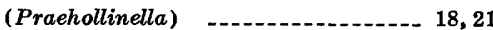

pumila

sella

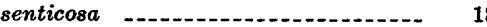

sp - - 18, 22

Hollinellidae -

Hollinidae -

Hollininae

hypercala, Parabolbina --.--_..--.-- 17

\section{I}

informis, Flaccivelum

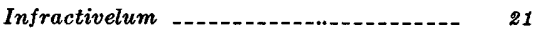
acuminatum -_._._._.-. 6, 21, 22, pl. 8 spiculosum _........._._. 6, 21, 22, pl. 8

insericus, Neoaparchites _._-_._-_. 6, 28, pl. 10 Punctaparchites -...-...-_..- 28 insolens, Hollina insolita, Abditoloculina $\quad \begin{array}{r}\text { Page } \\ 16\end{array}$

insolita, Abditoloculina
inventa, Voronina.--16 (Invisibia), Cavellina -...-.-- $s 7$ porrecta, Cavellina -..--..-.-.-.-. 38 sp., Cavellina _..........-. 7, s7, pl. 14

\section{J}

Jeffersonville, Ind -................-. 7

Jeffersonville Limestone ..._._._... 7,20

Jordanites -

\section{$\mathbf{K}$}

Kalkberg Limestone Kirkbyella (Kirkbyella) - - 24 sp (Kirkbyella), Kirkbyella -...- 24 sp., Kirkbyella _._._._._._._. 6, 24, 9 Kirkbyellidae -

Kloedenellidae -

Knoxites argutula -...-..- 15

Koneprusia subterarmata

rekov beds, Salair district, Siberia, U.S.S.R. - 36

Kuresaaria blackstonensis gotlandica - -

\section{L}

leguminoides, Bairdia _...... 6, so,31, pl. 11 Leptobolbina Libumella $\begin{array}{lll}\text { circulata } & \ldots \ldots \ldots \\ \text { discoides } & \ldots & \ldots\end{array}$ sp 27

limitaris, Chironiptrum _....... 6, 22, pl. 8 linearis, Hanaites ..... 6, 24, 25, 26, pl. 9 Localities

Louisville, $\mathrm{Ky}$ lyoni, Treposella

\section{M}

McCann Hill Chert collection localites fauna

lithology

medialis, Adelphobolbina megalia, Adelphobolbina

Mesomphalus hartleyi

Michelle Formation collection localites fauna lithology

Microcheilinella sp

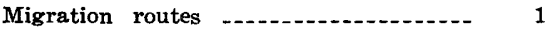
minuta, Berounella _.......... 6, 34, pl. 12 mirabilis, Eurychilina _._._._._. 24, 25 Monograptus yukonensis _...... 2, 8 mucronata, Bairdia _............. 30 multispinosus, Falsipollex _.... 6, 17, pl. 7

\section{$\mathrm{N}$}

Nation River Formation

navicula, Acanthoscapha Bairdia

Neoaparchites
Page

insericus obsoletus Neocraterellina crescentifera Newsomites _.................... 7, 38 notabilis pertumidus profusus _-_._. sp Nodella Nodellidae -...- 24 nodilineata, Alaskabolbina _.... 6, 14, 15, pl. 5 notabilis, Newsomites .............-. 38 Novgorod district, U.S.S.R.

Nowakia barrandei _-_....... parabarrandei

\section{0}

oblonga, Craterellina

Obotritia eifeliensis sp obsoletus, Neoaparchites _.......... 28 Primitia Ogilvie Formation -

Ogilvites -..-15 argutula -.....-.... 16 bicornis oiostathmicum, Chironiptrum _....... 22, 23 opisthorhysa, Barychilina orthoclefta, Thlipsurella Ostracode collections

Ostracode indet. 1 indet. 2 -........ $7,40, \mathrm{pl} .14$ indet. 3 -............. 7, 40, pl. 14 Ostthuringer, Germany _........ $?$ ovata, Ellesmeria -

\section{$\mathbf{P}$}

Pachydomellid indet. 1 _....... 7, 38, pl. 14 indet. 2 Pachydomellidae papillata, Adelphobolbina _............ 20 papillosa, Adelphobolbina _............ 20 Parabolbina granosa

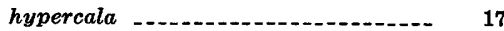
pulchella - sp

Parabolbininae -

Paraparchitidae -........ 28

Paraspirifer acuminatus Zone paucituberculata, Hollinella _.... 6, 18, pl. 7 pertumidus, Newsomites _........... 31, 38 Phlyctiscapha pinguis, Adelphobolbina platum, Proplectrum _...- 24 platus, Hanaites -... 25, 26 plauta, Hollinella

Plum Brook Formation _........ 39

Poloniella -..- so (Framella) -.... so scheii _............... 6, 8, $30, \mathrm{pl} 11$

Polygnathus dehiscens foveolatus lenzi -

Porcupine River porrecta, Cavellina (Invisibila) -... 38 (Praehollinella), Hollinella praepilata praepilata, Praepilatina -..- 36 sibirica, Praeplatina _..._. 6, 8, 36, pl. 13

Praepilatina praepilata praepilata praepilata sibirica 


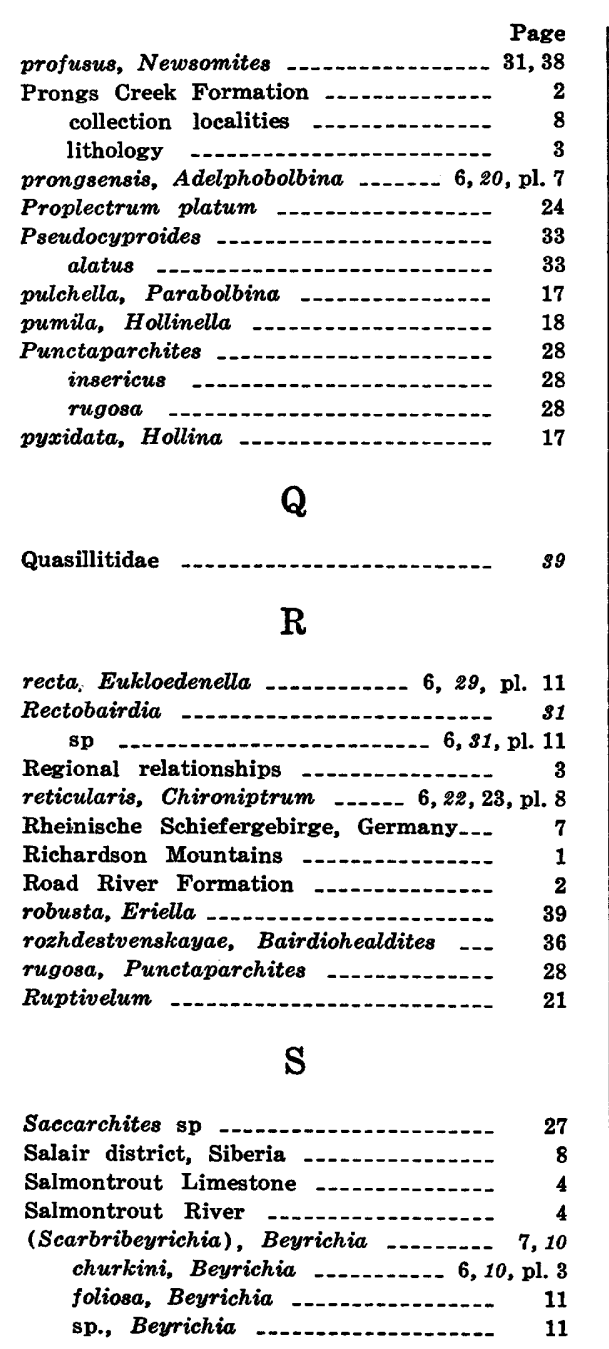

Page
32

scapulatus, Bairdiohealdites scheii, Poloniella (Framella) -- 6, 8, 30, pl. 11

Schoharie Formation -.......-.-.-.-.-- 7

Schohariella

Sedimentation

sella, Hollinella

senticosa, Hollinella -...-...-.-.-- 18

serratulus, Subartichites - -

Shidelerites $-1, \ldots$

typus _..._............ 32, 33, pl. 11

yukonensis -

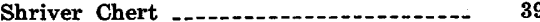

sibirica, Praepilatina praepilata_ $6,8,36, \mathrm{pl} .13$ sohni, Bairdiolites - -

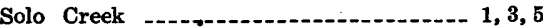

solo, Yukonibeyrichia .......... 6, 11, 1s, pl. 4 soloensis, Eukloedenella spicata, Adelphobolbina -...-...-... 20 spiculosum, Infractivelum ..... 6, 21, 22, pl. 8 spinosus, Hanaites _......... 6, 24, 25, pl. 9 Stratigraphy --stellata, Treposella -................. 9

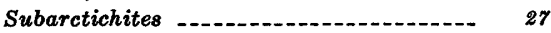
crossotus - - 27 serratulus _............. 6, 27, pl. 9 sulcifrons, Eukloedenella

\section{$\mathbf{T}$}

Tecnomorph, defined _._._. 18

Teicherticeras lenzi -..... 5

teleutaea, Flaccivelum _..........-. 21

Terminology

Tetracornella

Thlipsurella orthoclefta

Thlipsuridae -

Trail River -....

transversocostata, Bairdia _..._.... 31

Treposella -..-. 7, 9 borealis lyoni _.................. 6, $9,10, \mathrm{pl} .1$ stellata
Page

Tricornina caurina

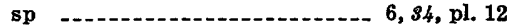
Tricorninidae trilobata, Adelphobolbina truncatum, Abortivelum -..-....- 6,19, pl. 6

Trypetera barathrota -..- 37 sp

Tubulibairdia _..... 38,39 sp _..... Turkestanella acuaria -..-......-.-. 5 typus, Shidelerites _........... 32, 33, pl. 11

\section{$\mathrm{U}$}

umbilicata, Eukloedenella Ural Mountains _...... 7, 28, 29

\section{V}

voronensis, Voronina Voronina inventa _................ 6,7, $37, \mathrm{pl} .13$ voronensis

W

Waldron Shale whiteavesi, Aparchites ... 29 Windom Member, Moscow Shale _...-. 21

\section{$\mathrm{Y}$}

Yukon Shelf _-.-- 1 yukonensis, Monograptus 8 Shidelerites _. Yukonibeyrichia -

Yukonibeyrichia -....-..- 11 solo -............... 6, 11, 18, pl. 4 yukonensis $\ldots \ldots \ldots, 11,12,13, \mathrm{pl} .4$ 
PLATES 1-14 


\section{PLATE 1}

[All figures $\times 30$ ]

Figures 1,2. Mesomphalus? sp. (p. 9).

Broken tecnomorphic right and left valves from the Prongs Creek Formation, Ludvigsen collection V-3. Figured specimens, GSC 29439, 29438.

3,4. Treposella sp. cf. T. lyoni (Ulrich, 1891) (p. 9).

Immature tecnomorphic right and left valves from the McCann Hill Chert, USGS collection 7037-SD. Figured specimens, USNM 173728, 173729.

5-10. Treposella borealis n. sp. (p. 9).

5. Small tecnomorphic left valve from the McCann Hill Chert, USGS collection 6492-SD. Paratype, USNM 170351.

6. Tecnomorphic right valve from the Prongs Creek Formation, Ludvigsen collection V-3. Paratype, GSC 29453.

7. Ventral view of holotype, USNM 170352, showing the treposelline bridges across the ventral surface of the crumina. McCann Hill Chert, USGS collection 6492-SD.

8. Lateral view of heteromorphic right valve, holotype, USNM 170352.

9. Interior view of a heteromorphic left valve from the McCann Hill Chert, USGS collection 7032-SD, showing the strut across the crumina. Paratype, USNM 173731.

10. Large tecnomorphic right valve from the McCann Hill Chert, USGS collection 6492-SD. Paratype, USNM 173730. 


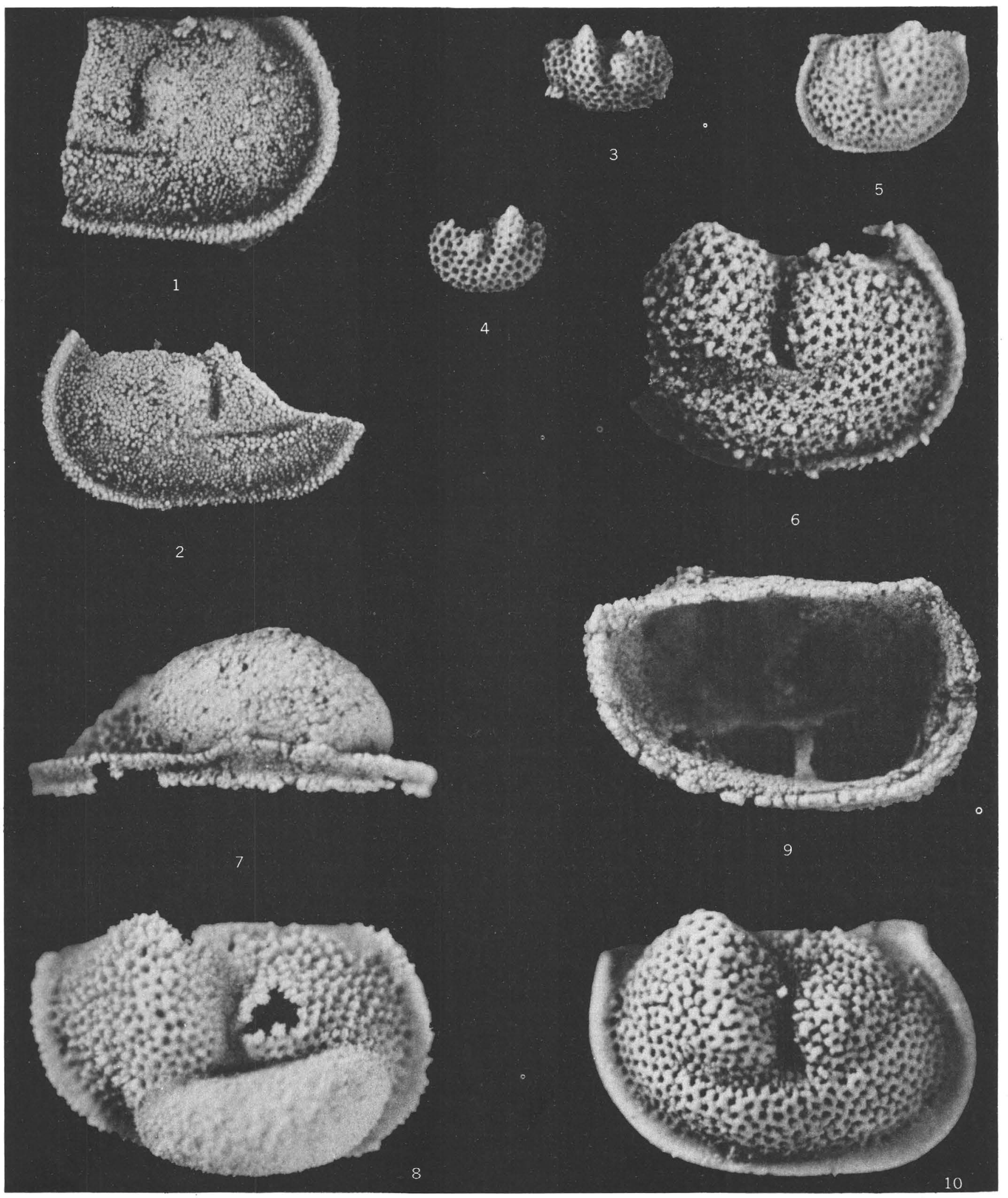

MESOMPHALUS? AND TREPOSELLA 


\section{PLATE 2}

Figures 1-8. Beyrichia (Beyrichia) brabbi n. sp., $\times 30$ (p. 10).

1. Small tecnomorphic left valve, paratype, GSC 29474, from the Prongs Creek Formation, Ludvigsen collection V-3.

2. Small tecnomorphic right valve, paratype, USNM 173732, from the McCann Hill Chert, USGS collection 6492-SD.

3. Tecnomorphic left valve, paratype, USNM 173733, from the McCann Hill Chert, USGS collection 6492-SD.

4. Tecnomorphic left valve, paratype, GSC 29473, from the Prongs Creek Formation, Ludvigsen collection V-3.

5. Ventral view of heteromorphic right valve, paratype, USNM 173734, from the McCann Hill Chert, USGS collection 6492-SD.

6. Large tecnomorphic right valve, paratype, USNM 170347, from the McCann Hill Chert, USGS collection 6492-SD.

7. Heteromorphic right valve, holotype, USNM 170346, from the McCann Hill Chert, USGS collection 6492-SD.

8. Heteromorphic left valve, paratype, USNM 173736, from the McCann Hill Chert, USGS collection 6492-SD. 


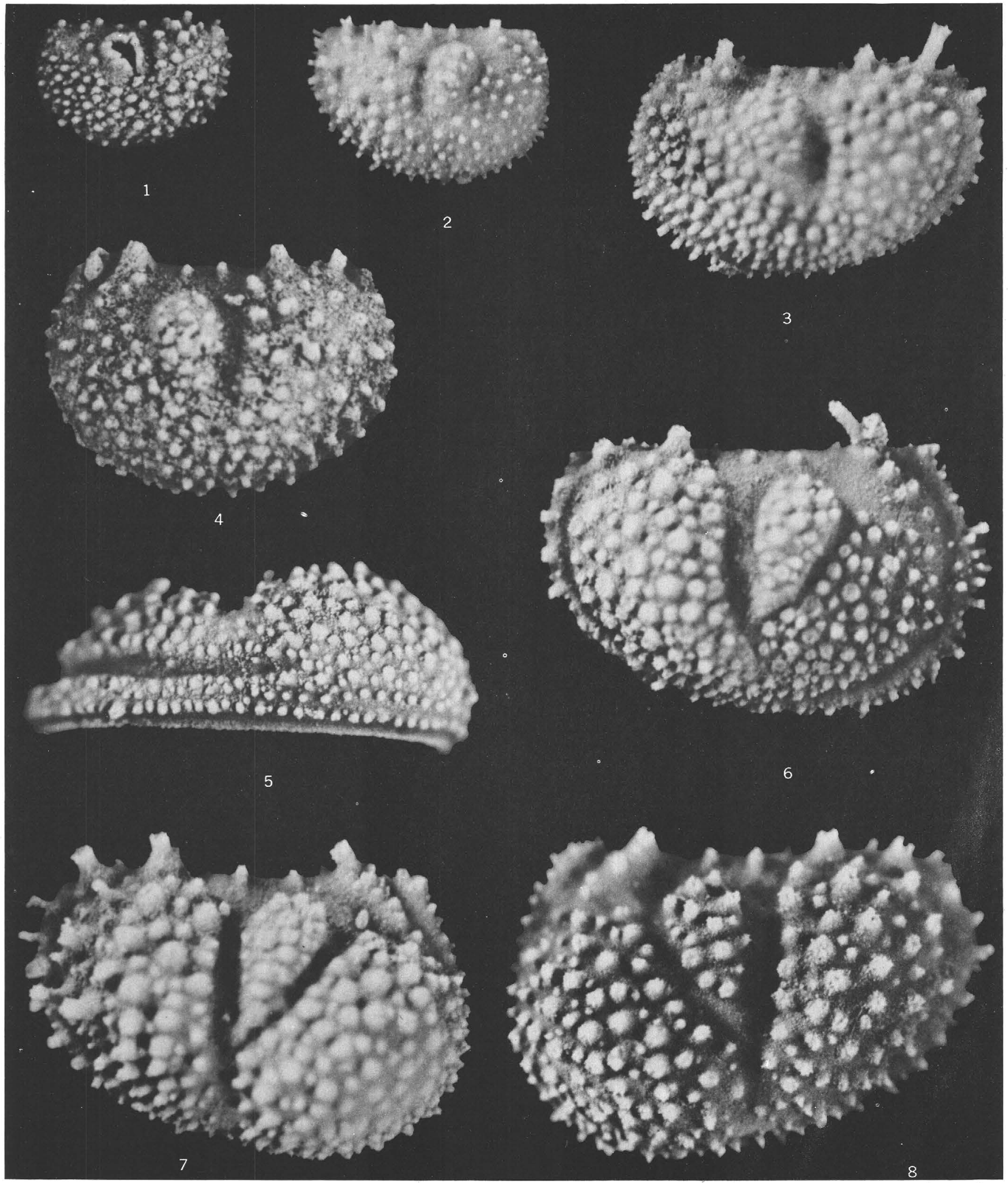




\section{PLATE 3}

FIGURES 1-9. Beyrichia (Scabribeyrichia) churkini n. sp., $\times 30$ (p. 10).

1. Small tecnomorphic right valve, paratype, USNM 173737, from the McCann Hill Chert, USGS collection 6492-SD.

2. Small tecnomorphic left valve, paratype, USNM 173738, from the McCann Hill Chert, USGS collection 6492-SD, showing four spines fusing to form calcarine spine.

3, 4. Tecnomorphic right valves, paratypes, GSC 29472, 29471, from the Prongs Creek Formation, Ludvigsen collection $\mathrm{V}-3$.

5. Large tecnomorphic left valve, paratype, USNM 170348, from the McCann Hill Chert, USGS collection 6492-SD, showing unusually well developed fissus.

6, 7. Ventral and lateral views of heteromorphic right valve, holotype, USNM 170349, from the McCann Hill Chert, USGS collection 6492-SD.

8. Tecnomorphic left valve, paratype, GSC 29470, from the Prongs Creek Formation, Ludvigsen collection V-5.

9. Heteromorphic left valve, paratype, GSC 29469, from the Prongs Creek Formation, Ludvigsen collection V-3 . 

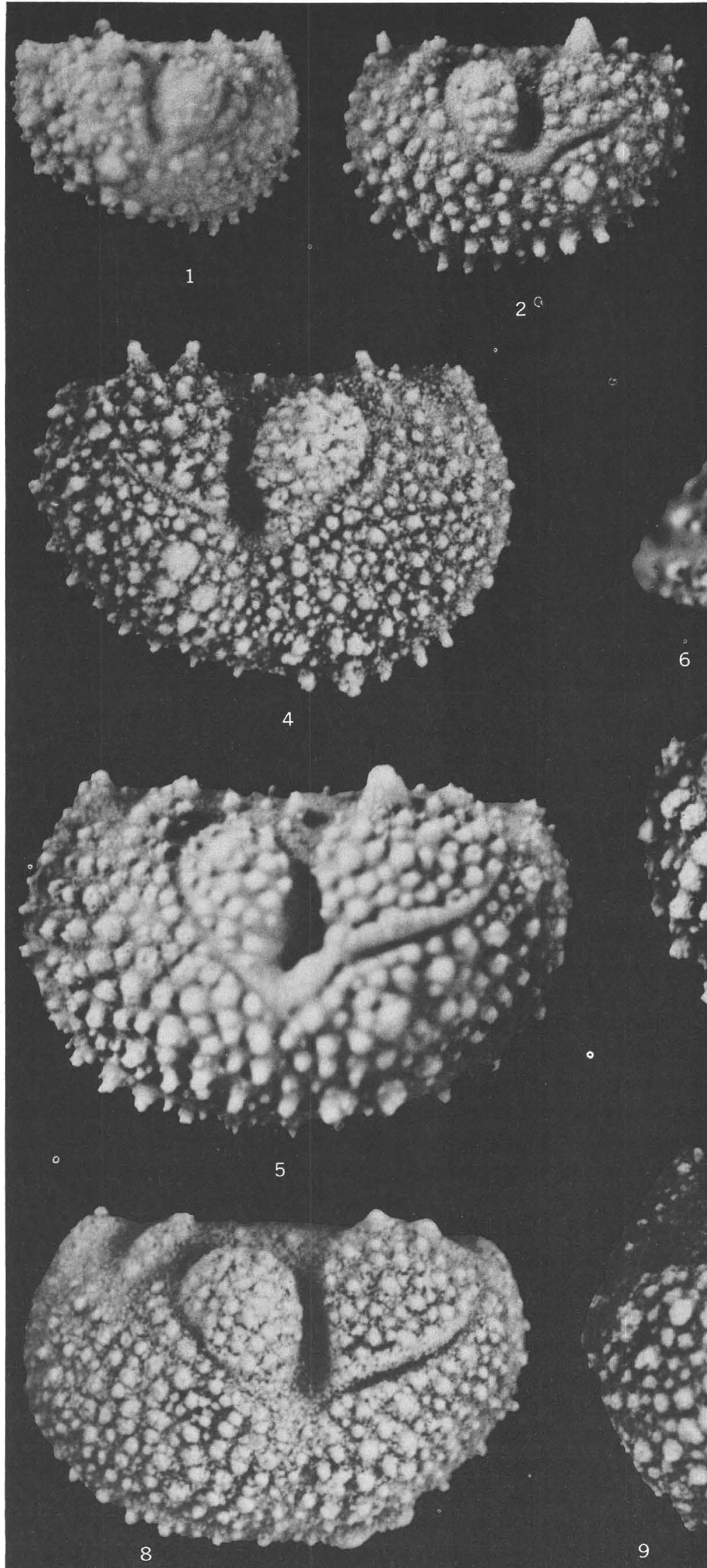

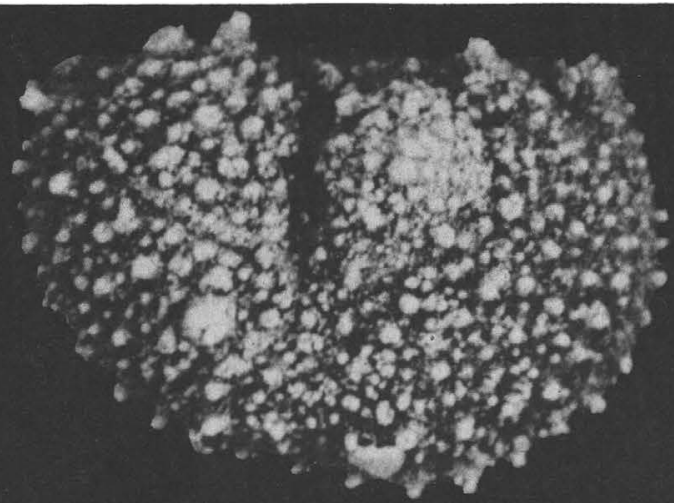

3
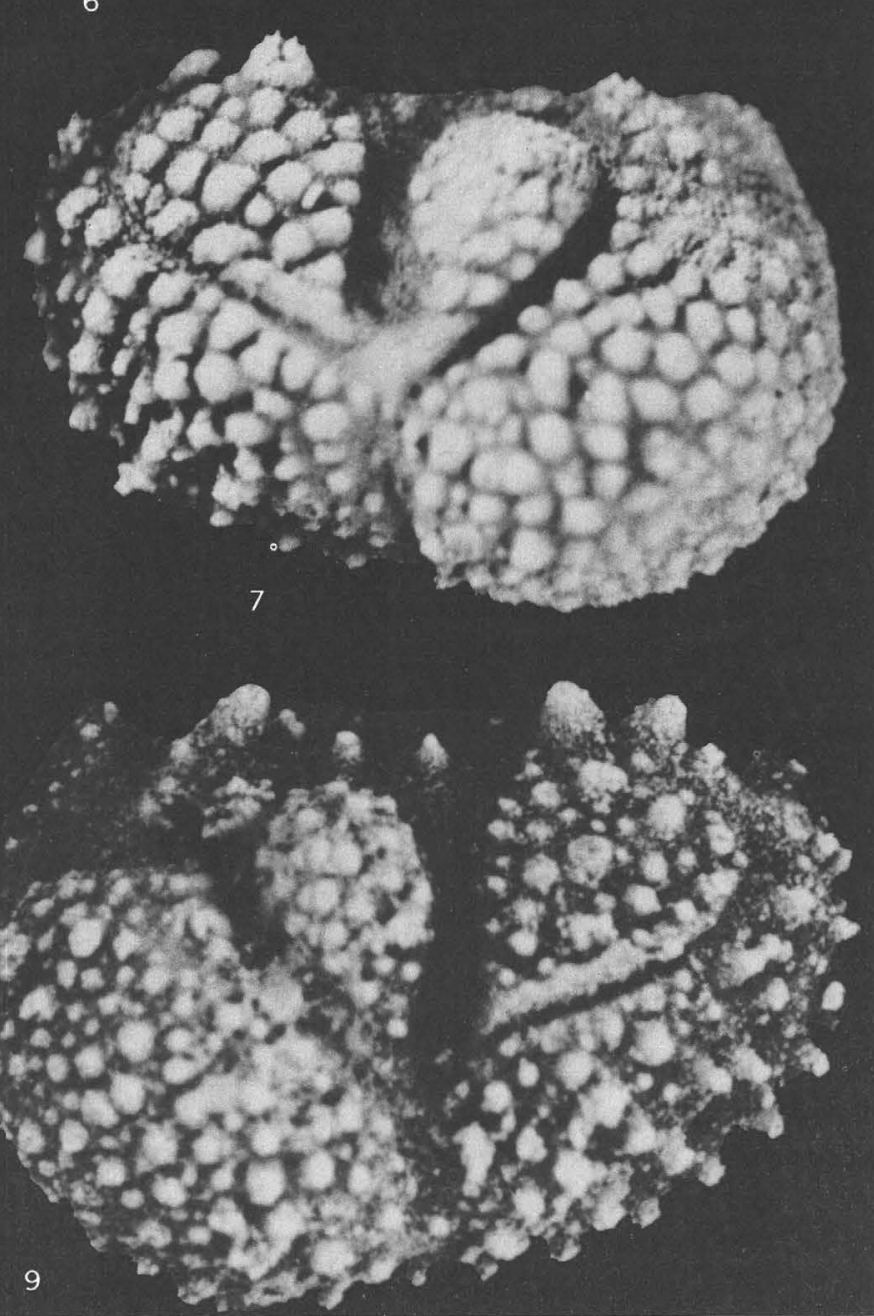

BEYRICHIA (SCABRIBEYRICHIA) 


\section{PLATE 4}

FiguRES 1-4. Yukonibeyrichia solo n. sp. (p. 13).

1. Tecnomorphic left valve, paratype, GSC 29436, from the Prongs Creek Formation, Ludvigsen collection V-3.

2. Tecnomorphic right valve, holotype, GSC 29435, from the Prongs Creek Formation, Ludvigsen collection V-3.

3,4. Heteromorphic left valve, lateral and ventral views, paratype, GSC 29437, from the Prongs Creek Formation, Ludvigsen collection V-4.

5-11. Yukonibeyrichia yukonensis n. gen., n. sp. (p. 12),

5,6. Broken heteromorphic right valve, lateral and ventral views, paratype, USNM 173740, from the McCann Hill Chert, USGS collection 7032-SD.

7. Small tecnomorphic right valve, paratype, GSC 29434, from the Prongs Creek Formation, Ludvigisen collection $\mathrm{V}-3$.

8. Small tecnomorphic right valve, paratype, USNM 173741, from the McCann Hill Chert, USGS collection 7032-SD.

9. Small tecnomorphic left valve, paratype, USNM 170345, from the McCann Hill Chert, USGS collection 6492-SD.

10. Tecnomorphic left valve, holotype, GSC 29432, from the Prongs Creek Formation, Ludvigsen collection V-3.

11. Heteromorphic left valve, paratype, GSC 29433, from the Prongs Creek Formation, Ludvigsen collection V-3. 


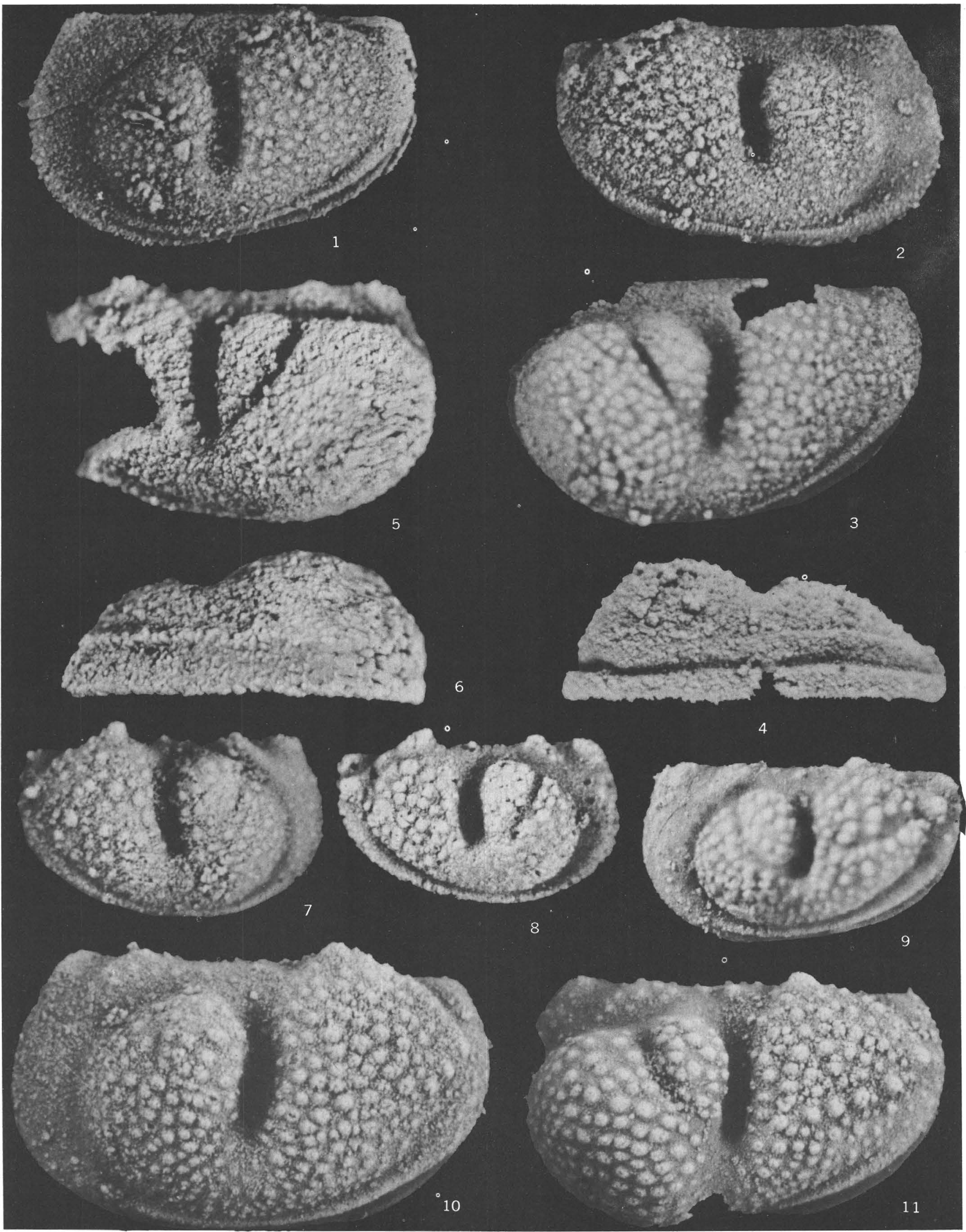




\section{PLATE 5}

[All figures $\times 30$ ]

1-6. Alaskabolbina nodilineata n. sp., from the Prongs Creek Formation, Ludvigsen collection V-3 (p. 14).

1. Lateral view of heteromorphic? right valve, holotype, GSC 29512.

2. Interior of holotype showing possible cruminal structure.

3. Ventral view of holotype showing double row of subvelar tubercles.

4-6. Lateral, interior, and dorsal views of heteromorphic? left valve, paratype, GSC 29513.

7-10. Alaskabolbina? sp., from the McCann Hill Chert, USGS collection 7037-SD (p. 15).

7. Small right valve, figured specimen, USNM 173840.

8. Small left valve, figured specimen USNM 173841.

9. Larger broken right valve, figured specimen, USNM 173842, showing more extended velum.

10. Small papillose right valve, figured specimen, USNM 173843, lacking dorsal cusps.

11, 12. Alaskabolbina sp. (p. 15).

11. Small immature right valve, figured specimen, USNM 173844, from the McCann Hill Chert, USGS collection 7037-SD, showing dorsal cusps.

12. Immature left valve, figured specimen, USNM 173845, from the McCann Hill Chert, USGS collection 7037-SD. Possibly juvenile form of Alaskabolbina nodilineata, n. sp.

13-15. Alaskabolbina unilineata n. gen., n. sp. (p. 14).

13. Right valve, holotype, USNM 173745, from the McCann Hill Chert, USGS collection 6492-SD.

14. Ventral view of holotype showing single toric ridge.

15. Dorsal view of holotype.

16-21. Alaskabolbina bilineata n. sp., from the Michelle Formation, Ludvigsen collection II-11 (p. 14).

16. Broken left valve, paratype, GSC 29465, showing dorsal tubercles.

17. Broken left valve, paratype, GSC 29467.

18. Broken right valve, paratype, GSC 29468.

19. Broken right valve, paratype, GSC 29466.

20. Left valve, holotype, GSC 29464.

21. Ventral view of holotype showing double toric ridges. 


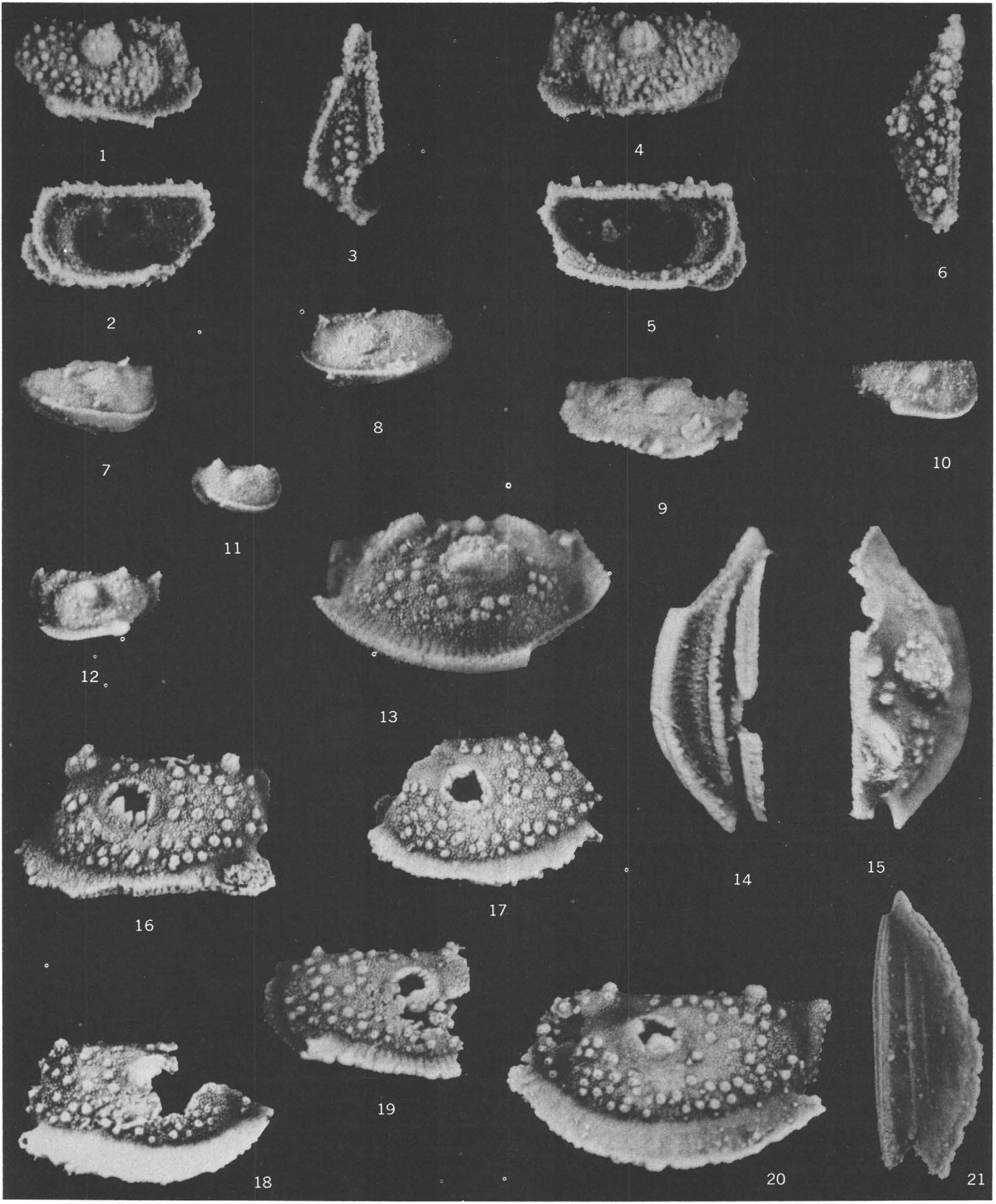

ALASKABOLBINA AND ALASKABOLBINA? 


\section{PLATE 6}

FiguRE

1. Ogilvites bicornis n. sp. (p. 15).

[All figures $\times 30]$

Left(?) lateral view of holotype, GSC 29454, from the Prongs Creek Formation, Ludvigsen collection V-3.

2-8. Abditoloculina clausa n. sp., from the McCann Hill Chert (p. 16).

2-4. Left-lateral, right-lateral, and ventral views of the holotype, USNM 170338, a heteromorphic carapace, USGS collection 6492-SD. Figure 4 shows the closed loculi characteristic of the species.

5,6. Ventral and left-lateral views of a tecnomorphic carapace, paratype, USNM 173746, USGS collection 6492-SD.

7, 8. Exterior and interior views of a heteromorphic left valve, paratype, USNM 173747, showing loculi, USGS collection 7033-SD.

9. Abditoloculina clausa? (p. 16).

Lateral view of an immature tecnomorphic right valve from the McCann Hill Chert, USGS collection 7033-SD. Figured specimen, USNM 173750.

10-16. Abortivelum truncatum n. gen., n. sp., from the McCann Hill Chert, USGS collection 7032-SD (p. 19).

10,11. Right-lateral and ventral views of a heteromorphic carapace, paratype, USNM 173751.

12-14. Right-lateral, ventral, and dorsal views of a tecnomorphic carapace, paratype, USNM 173753.

15, 16. Exterior and interior views of a heteromorphic left valve, the holotype, USNM 173752.

17-22. Adelphobolbina aliquanta n. sp. (p. 19).

17. Immature tecnomorphic right val right valve, paratype, USNM 170341, from the McCann Hill USGS collection $6492-S D$.

18. Lateral view of a tecnomorphic right valve, paratype, USNM 170341, from the McCann Hill Chert, USGS collection 6492-SD. This specimen was originally thought to be a heteromorph.

19. Tecnomorphic left valve, paratype, USNM 173756, from the McCann Hill Chert, USGS collection 6492-SD, showing anterodorsal cusp.

20,21. Exterior and interior views of a heteromorphic right valve, the holotype, USNM 173755, from the McCann Hill Chert, USGS collection 6492-SD, showing the character of the velum.

22. Tecnomorphic left valve from the Michelle Formation, Ludvigsen collection II-13, paratype, GSC 29497.

23. Hollina sp. (p. 17).

Tecnomorphic right valve, figured specimen, GSC 29441, from the Prongs Creek Formation, Ludvigsen collection V-3. 


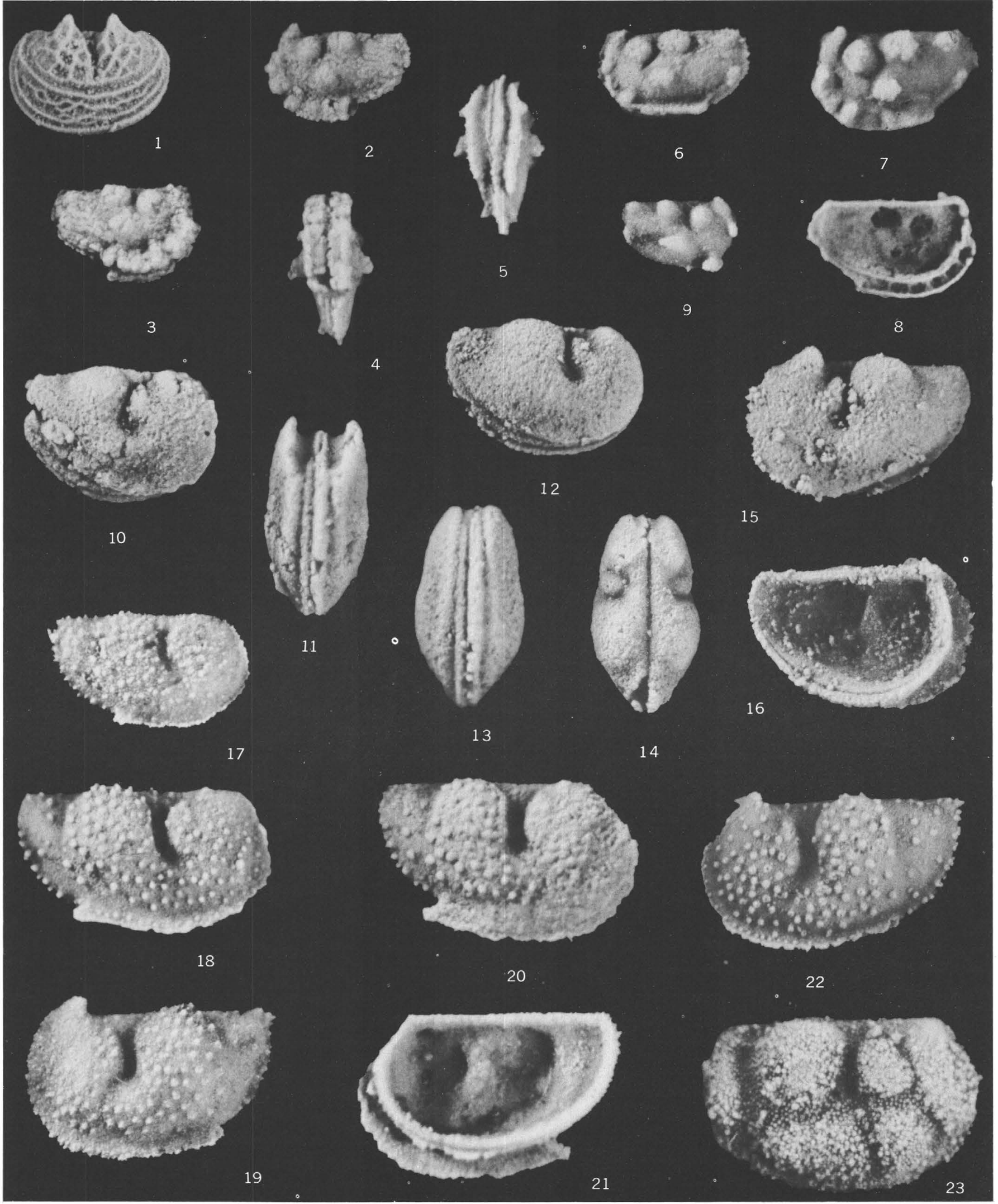

OGILVITES, ABDITOLOCULINA, ABORTIVELUM, ADELPHOBOLBINA, AND HOLLINA 


\section{PLATE 7}

FIGURES 1-3. Hollinella ludvigseni n. sp. (p. 18).

[All figures $\times 30$ ]

1. Tecnomorphic right valve, paratype, USNM 173764, from the McCann Hill Chert, USGS collection 6492-SD.

2. Tecnomorphic right valve, holotype, GSC 29462, from the Prongs Creek Formation, Ludvigsen collection V-3.

3. Heteromorphic right valve, paratype, GSC 29463, from the Prongs Creek Formation, Ludvigsen collection V-3.

4,5. Adelphobolbina sp. cf. A. medialis Stover, 1956 (p. 20). Technomorphic left and right valse, figured specimens, USNM 173759, 173760, from the McCann Hill Chert, USGS collection 6492-SD.

6-8. Hollinella paucituberculata n. sp., from the Michelle Formation, Ludvigsen collection II-13 (p. 18).

6. Heteromorphic right valve, paratype, GSC 29495.

7. Tecnomorphic left valve, paratype, GSC 29496.

8. Heteromorphic left valve, holotype, GSC 29494.

9-13. Adelphobolbina prongsensis n. sp., from the Prongs Creek Formation (p. 20).

9. Tecnomorphic left valve, paratype, GSC 29501, Ludvigsen collection V-3.

10. Teenomorphic left valve, paratype, GSC 29502, Ludvigsen collection V-4, showing papillose posterior.

11. Heteromorphic right valve, holotype, GSC 29498 , Ludvigsen collection V-3.

12. Heteromorphic left valve, paratype, GSC 29500, Ludvigsen collection V-3.

13. Heteromorphic left valve, paratype, GSC 29499, Ludvigsen collection V-3.

14-16. Falsipollex? multispinosus n. sp. (p. 17).

14. Broken tecnomorphic left valve, paratype, USNM 173762, from the McCann Hill Chert, USGS collection 6492-SD.

15. Heteromorphic right valve, holotype, USNM 173761, from the McCann Hill Chert, USGS collection 7032-SD.

16. Interior of holotype showing dolonal pouch. 

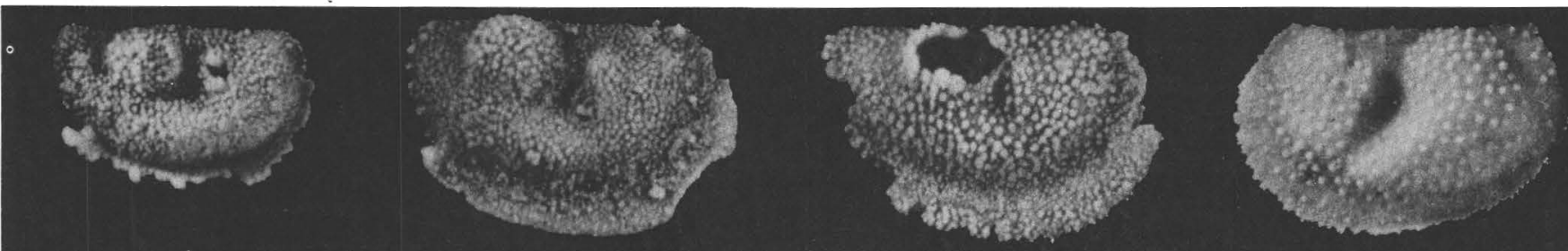

1

2

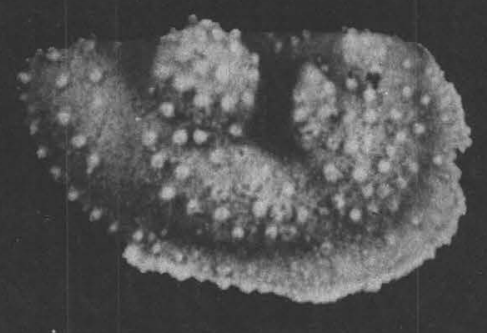

6

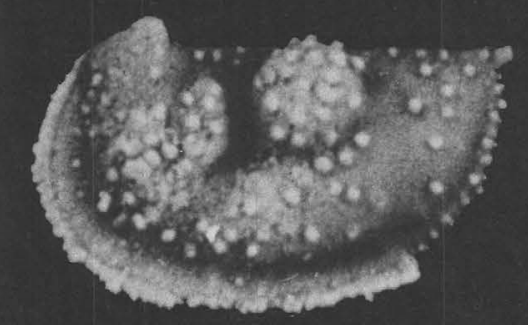

8

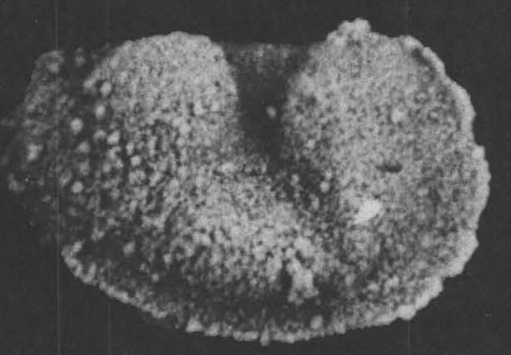

11
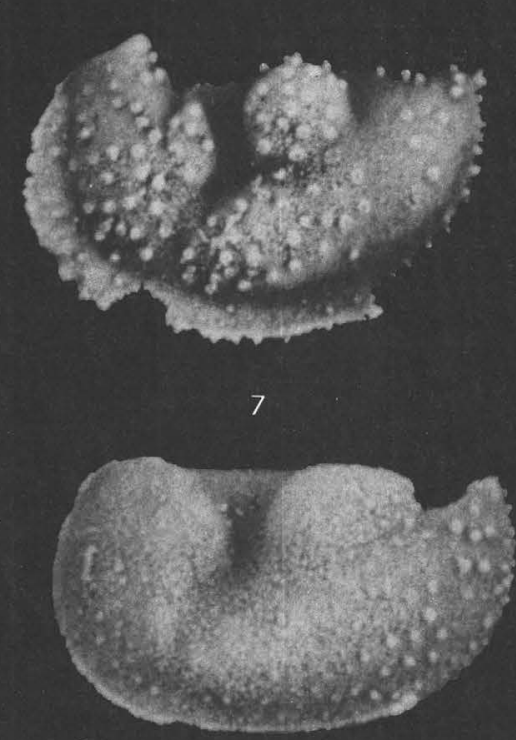

9

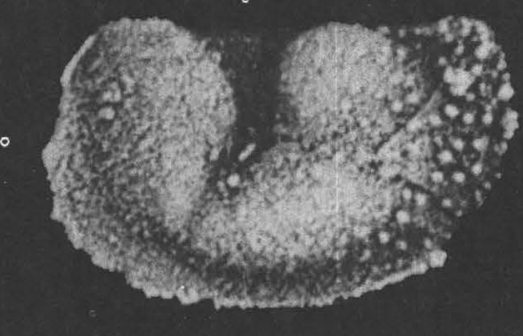

12

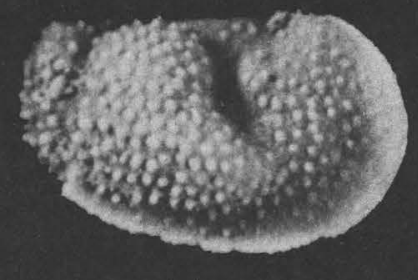

5

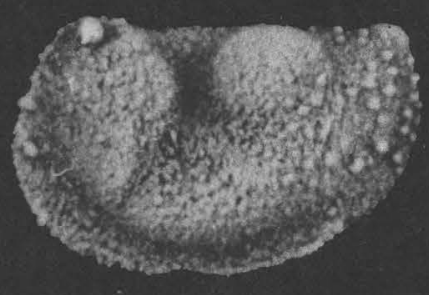

10

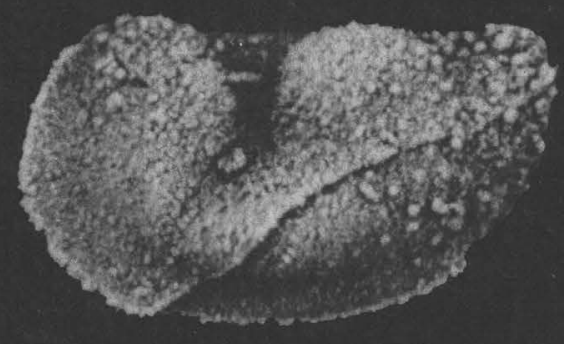

13

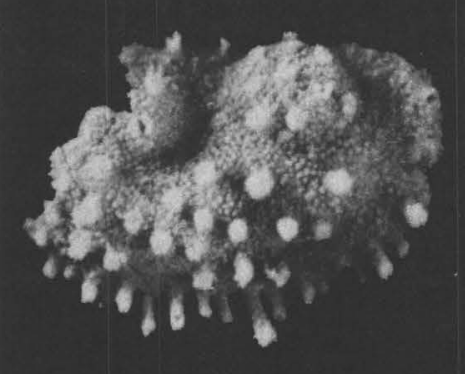

14
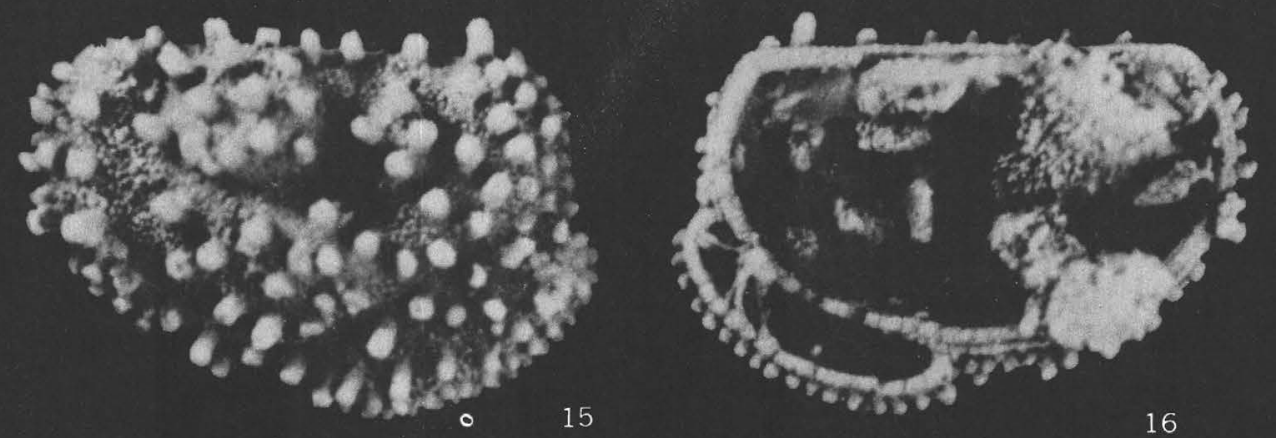


\section{PLATE 8}

FIGURE

1. Obotritia? sp. (p. 23).

[All figures $\times 30$ except as noted]

Left valve, figured specimen, USNM 173774, from the McCann Hill Chert, USGS collection, 7037-SD.

2-8. Chironiptrum limitaris n. sp., (p. 22).

2. Left-lateral view of carapace, paratype, USNM 173769, from the McCann Hill Chert, USGS collection 6492-SD.

3,4. Right-lateral and left-lateral views of carapace, paratype, USNM 170337, from the McCann Hill Chert, USGS collection 6492-SD.

5. Right valve, paratype, GSC 29455, from the Prongs Creek Formation, Ludvigsen collection V-3.

6, 7. Left-lateral and dorsal views of carapace, holotype, USNM 173770, from the McCann Hill Chert, USGS collection 7033-SD.

8. Right valve, paratype, USNM 173771, from the McCann Hill Chert, USGS collection 6492-SD.

9-14. Chironiptrum reticularis n. sp., from the Michelle Formation (p. 22).

9. Left valve, paratype, GSC 29459, Ludvigsen collection II-13.

10. Dorsal view of carapace, paratype, GSC 29461, Ludvigsen collection II-10.

11. Ventral view of carapace, paratype, GSC 29460, Ludvigsen collection II-10.

12. Left-lateral view of carapace, paratype, GSC 29458, Ludvigsen collection II-10.

13. Left-lateral view of carapace, paratype, GSC 29457, Ludvigsen collection II-10.

14. Right valve, holotype, GSC 29456, Ludvigsen collection II-10.

15,16. Flaccivelum sp., (p. 21).

Right valve, lateral and ventral views, figured specimen, GSC 29509, from the Michelle Formation, Ludvigsen collection II-10.

17, 18. Parabolbina sp., $\times 40$ (p. 17).

Ventral and left-lateral views of a carapace, figured specimen, GSC 29449, from the Michelle Formation, Ludvigsen collection II-10.

19-23. Infractivelum acuminatum n. gen., n. sp., from the Prongs Creek Formation (p. 21).

19. Tecnomorphic left valve, paratype, GSC 29506, Ludvigsen collection V-3.

20. Small tecnomorphic left valve, paratype, GSC 29507, Ludvigsen collection V-3.

21. Heteromorphic right valve, holotype, GSC 29503, Ludvigsen collection V-3.

22. Tecnomorphic right valve, paratype, GSC 29505, Ludvigsen collection V-4.

23. Heteromorphic right valve; paratype, GSC 29504, Ludvigsen collection V-3.

24-27. Infractivelum spiculosum n. sp., from the McCann Hill Chert (p. 22).

24. Tecnomorphic right valve, paratype, USNM 173766, USGS collection 7033-SD.

25. Tecnomorphic left valve, paratype, USNM 173765, USGS collection 7033-SD.

26. Tecnomorphic left valve, paratype, USNM 173767, USGS collection 6492-SD.

27. Heteromorphic left valve, holotype, USNM 107342, USGS collection 6492-SD. 


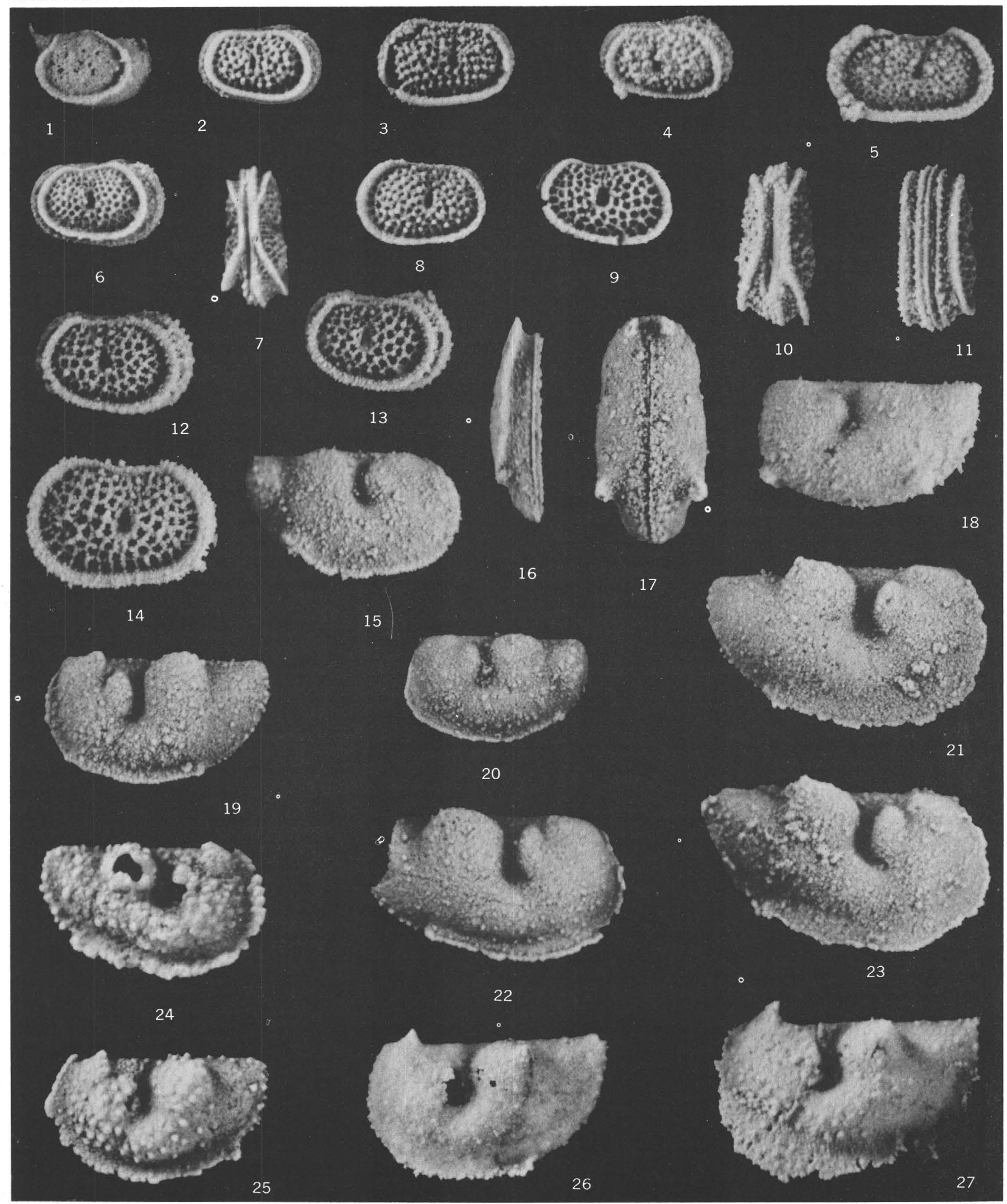

OBOTRITIA?, CHIRONIPTRUM, FLACCIVELUM, PARABOLBINA, AND INFRACTIVELUM 


\section{PLATE 9}

Figure 1. Kirkbyella (Kirkbyella) sp. (p. 24).

[All figures $\times 30$ ]

Left valve, figured specimen, USNM 173775, from the McCann Hill Chert, USGS collection 7037-SD.

2,3. Hanaites linearis n. sp., from the Prongs Creek Formation, Ludvigsen collection V-3 (p. 24).

2. Tecnomorphic left valve, paratype, GSC 29477.

3. Heteromorphic right valve, holotype, GSC 29478.

4-9. Hanaites brevis n. sp., from the McCann Hill Chert, USGS collection 6492-SD (p. 25).

4. Tecnomorphic right valve, paratype, USNM 173776.

5. Left-lateral view of small tecnomorphic carapace, paratype, USNM 173778.

6. Tecnomorphic left valve, paratype, USNM 170340.

7-9. Right-lateral, dorsal, and ventral views of heteromorphic carapace, holotype, USNM 173777.

10-15. Hanaites spinosus n. sp. (p. 25).

10. Small tecnomorphic right valve, paratype, USNM 173781, from the McCann Hill Chert, USGS collection 7033-SD.

11. Right-lateral view of heteromorphic carapace, paratype USNM 173782, from the McCann Hill Chert, USGS collection 6492-SD.

12. Dorsal view of heteromorphic carapace, paratype, USNM 173783, from the McCann Hill Chert, USGS collection 6492-SD.

13. Heteromorphic left valve, holotype, USNM 173780, from the McCann Hill Chert, USGS collection 6492-SD.

14. Tecnomorphic left valve, paratype, GSC 29479, from the Michelle Formation, Ludvigsen collection II-10.

15. Tecnomorphic left valve, paratype, USNM 170339, from the McCann Hill Chert, USGS collection 6492-SD.

16-24. Subarctichites serratulus n. sp. (p. 27).

16. Right-lateral view of holotype, USNM 173784, from the McCann Hill Chert, USGS collection 6492SD.

17. Dorsal view of holotype.

18. Ventral view of holotype showing rows of spinules.

19. Interior of broken carapace, paratype, USNM 173785, from the McCann Hill Chert, USGS collection 6492-SD, showing thin walls and narrow duplicature.

20. Left valve, paratype, USNM 170350, from the McCann Hill Chert, USGS collection 6492-SD.

21. Interior of left valve, paratype, GSC 29483, from the Prongs Creek Formation, Ludvigsen collection V-4.

22. Right valve, paratype, GSC 29486, from the Prongs Creek Formation, Ludvigsen collection V-3.

23. Interior of left valve, paratype, GSC 29484, from the Prongs Creek Formation, Ludvigsen collection V-3.

24. Interior of right valve, paratype, GSC 29485, from the Prongs Creek Formation, Ludvigsen collection V-3. 


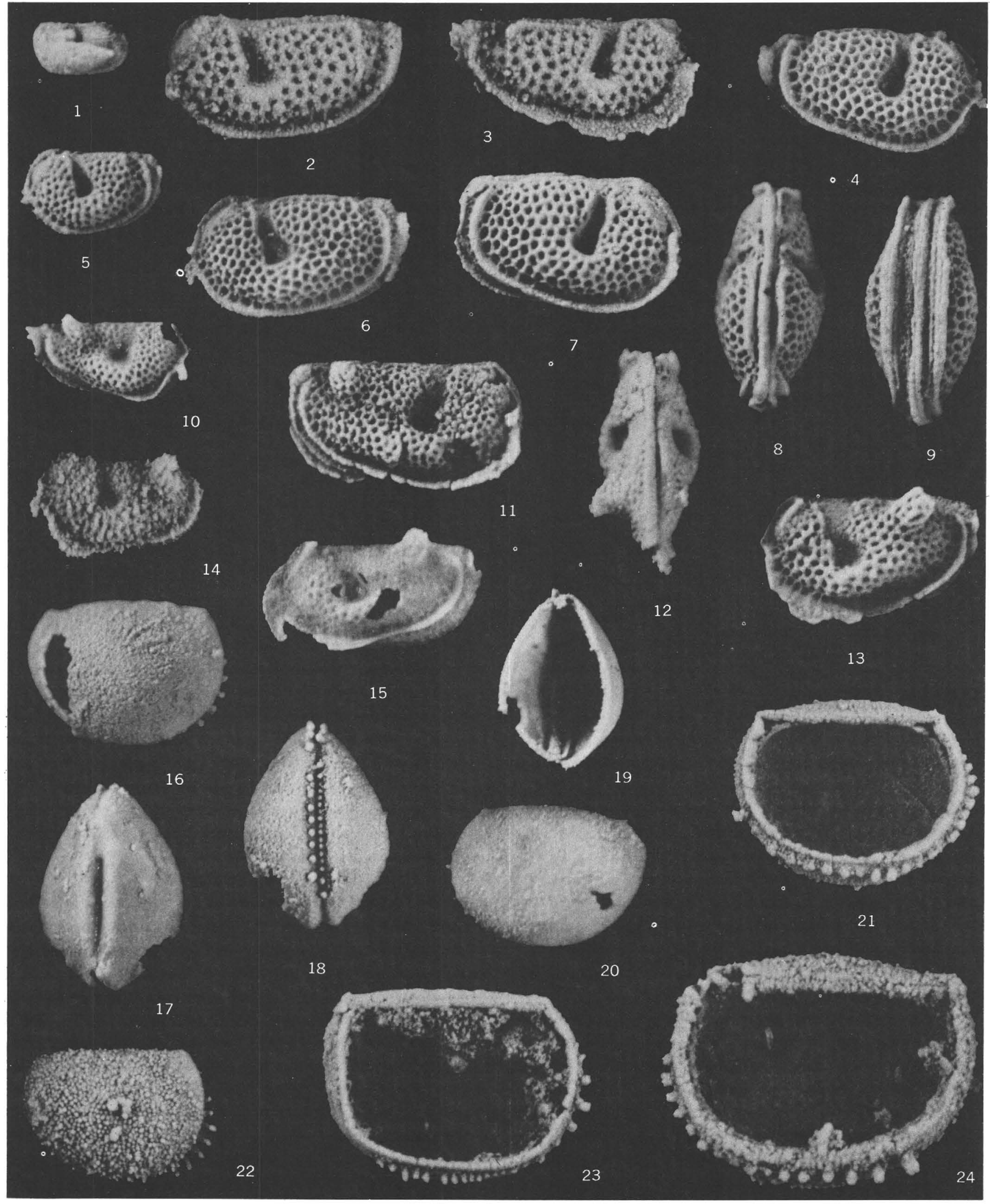

KIRKBYELLA, HANAITES, AND SUBARCTICHITES 


\section{PLATE 10}

[All figures $\times 30$ ]

Figures 1-5. Libumella sp. cf. L. discoides Rozhdestvenskaya, 1959 (p. 27).

1. Lateral view of carapace, figured specimen, GSC 29480, from the Prongs Creek Formation, Ludvigsen collection V-3.

2. Lateral view of carapace, figured specimen, GSC 29481, from the Prongs Creek Formation, Ludvigsen collection $\mathrm{V}-3$.

3. Lateral view of carapace, figured specimen, USNM 170344, from the McCann Hill Chert, USGS collection 6492-SD.

4,5. Lateral and dorsal views of larger carapace, figured specimen, USNM 173789, from the McCann Hill Chert, USGS collection 7032-SD.

6-8. Libumella sp. cf. L. circulata Rozhdestvenskaya, 1962 (p. 28).

6. Right valve, figured specimen, GSC 29482, from the Prongs Creek Formation, Ludvigsen collection $\mathrm{V}-3$.

7,8. Left valve, exterior and interior views, figured specimen, USNM 173790, from the McCann Hill Chert, USGS collection 7032-SD.

9-12. Neoaparachites? sp. aff. N.? insericus (Rozhdestvenskaya, 1962) (p. 28).

9, 10. Right valve, exterior and interior views, figured specimen, USNM 173791, from the McCann Hill Chert, USGS collection 6492-SD.

11,12. Right-lateral and dorsal views of carapace, figured specimen, USNM 173792, from the McCann Hill Chert, USGS collection 7032-SD.

13,14. "Aparchites" sp. aff. 'A." auriculiferus Rozhdestvenskaya, 1962 (p. 28).

Lateral and dorsal views of broken carapace, figured specimen, USNM 173793, from the McCann Hill Chert, USGS collection 7932-SD. 


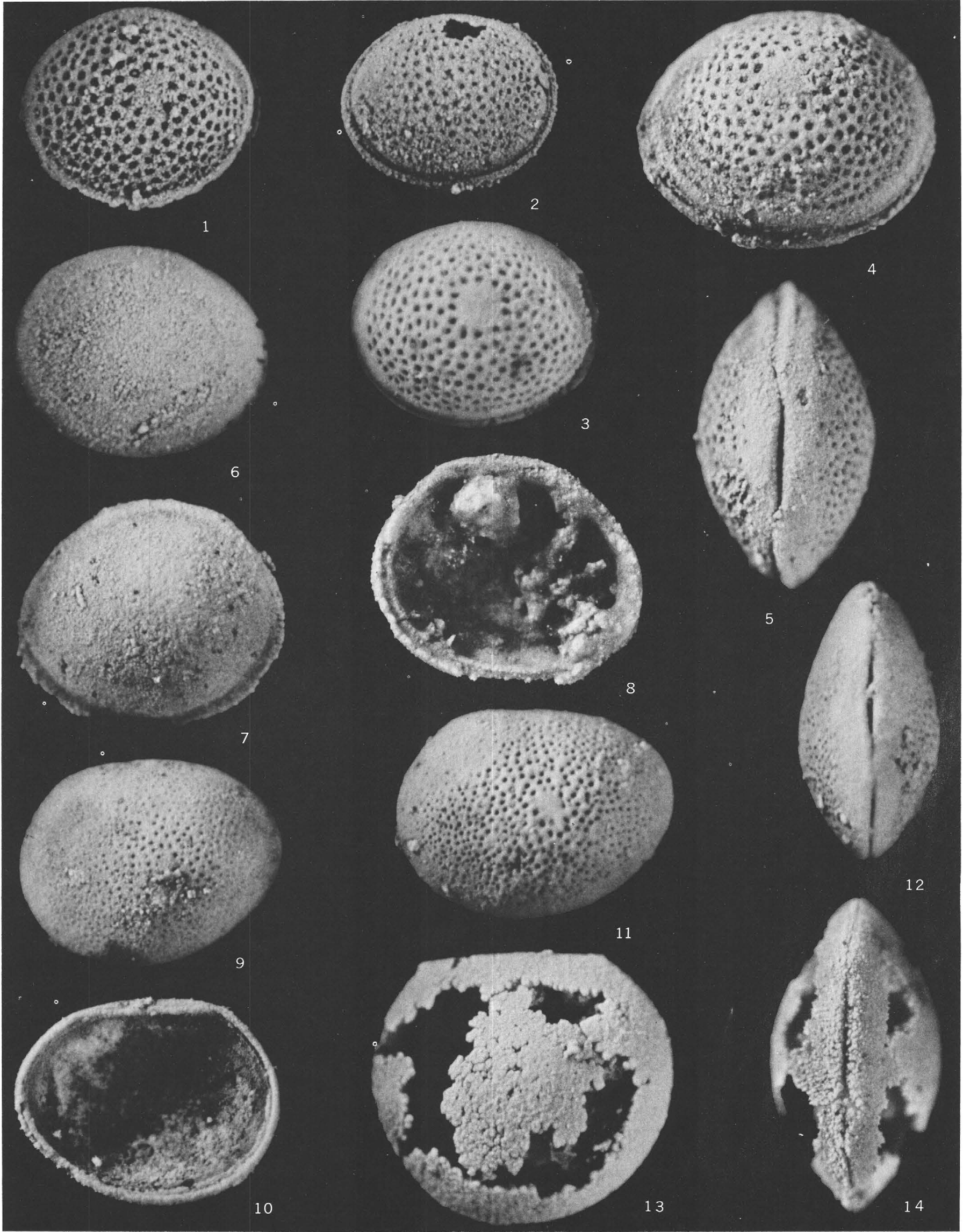




\section{PLATE 11}

Figures 1-4. Bairdia dejecta n. sp. (p. 30).

[A]l figures $\times 30$ ]

1. Right-lateral view of incomplete carapace, paratype, USNM 173801, from the McCann Hill Chert, USGS collection 7037-SD.

2-4. Right-lateral, left-lateral, and dorsal views of holotype, USNM 173800, from the McCann Hill Chert, USGS collection 7037-SD.

5, 6,9. Bairdiolites? sohni n. sp. (p. 31).

5, 6. Right-lateral and dorsal views of holotype, USNM 173803, from the McCann Hill Chert, USGS collection 7037-SD.

9. Interior of right valve, paratype, USNM 173804, from the McCann Hill Chert, USGS collection 7037-SD.

7,8. Beecherella? sp. (p. 33).

Dorsal and lateral views of right valve, figured specimen, USNM 173808, from the McCann Hill Chert, USGS collection 7037-SD.

10,11. Bairdia sp. cf. B. leguminoides Ulrich, 1891 (p. 30).

10. Right-lateral view of carapace, figured specimen, GSC 29508, from the Prongs Creek Formation Ludvigsen collection V-5.

11. Left valve, figured specimen, USNM 173799, from the McCann Hill Chert, USGS collection 7038SD.

12-14. Acanthoscapha sp. (p. 31).

Right-lateral, left-lateral, and dorsal views of poorly preserved carapace, figured specimen, USNM 173807, from the McCann Hill Chert, USGS collection 7037-SD.

15. Rectobairdia sp. (p. 31).

Left valve, figured specimen, USNM 173802, from the McCann Hill Chert, USGS collection 6492-SD.

16,17. Shidelerites typus Morris and Hill, 1951 (p. 32).

16. Right-lateral view of holotype, USNM 116420, from the Waldron Shale of Indiana.

17. Right-lateral view of paratype, USNM 116421a, showing anterior spine.

18. Shidelerites yukonensis n. sp. (p. 32).

Right-lateral view of carapace, holotype, GSC 29440, from the Prongs Creek Formation, Ludvigsen collection V-3.

19-24. Eukloedenella recta n. sp. (p. 29).

19,20. Left-lateral and dorsal views of carapace, paratype, USNM 173794, from the McCann Hill Chert, USGS collection 7037-SD.

21. Left-lateral view of carapace, paratype, GSC 29445, from the Michelle Formation, Ludvigsen collection II-10.

22. Right valve, paratype, GSC 29446, from the Michelle Formation, Ludvigsen collection II-11.

23. Right valve, holotype, GSC 29443, from the Michelle Formation, Ludvigsen collection II-10.

24. Dorsal view of carapace, paratype, GSC 29444, from the Michelle Formation, Ludvigsen collection II-10.

25-27. Poloniella (Framella) sp. aff. P. (F.) scheii Weyant, 1968, from the McCann Hill Chert, USGS collection 7037-SD (p. 30).

25. Left valve, figured specimen, USNM 173796.

26. Left valve, figured specimen, USNM 173798.

27. Left valve, figured specimen, USNM 173797.

28. Eukloedenella soloensis n. sp. (p. 29).

Right valve, holotype, GSC 29442, from the Prongs Creek Formation, Ludvigsen collection V-3. 


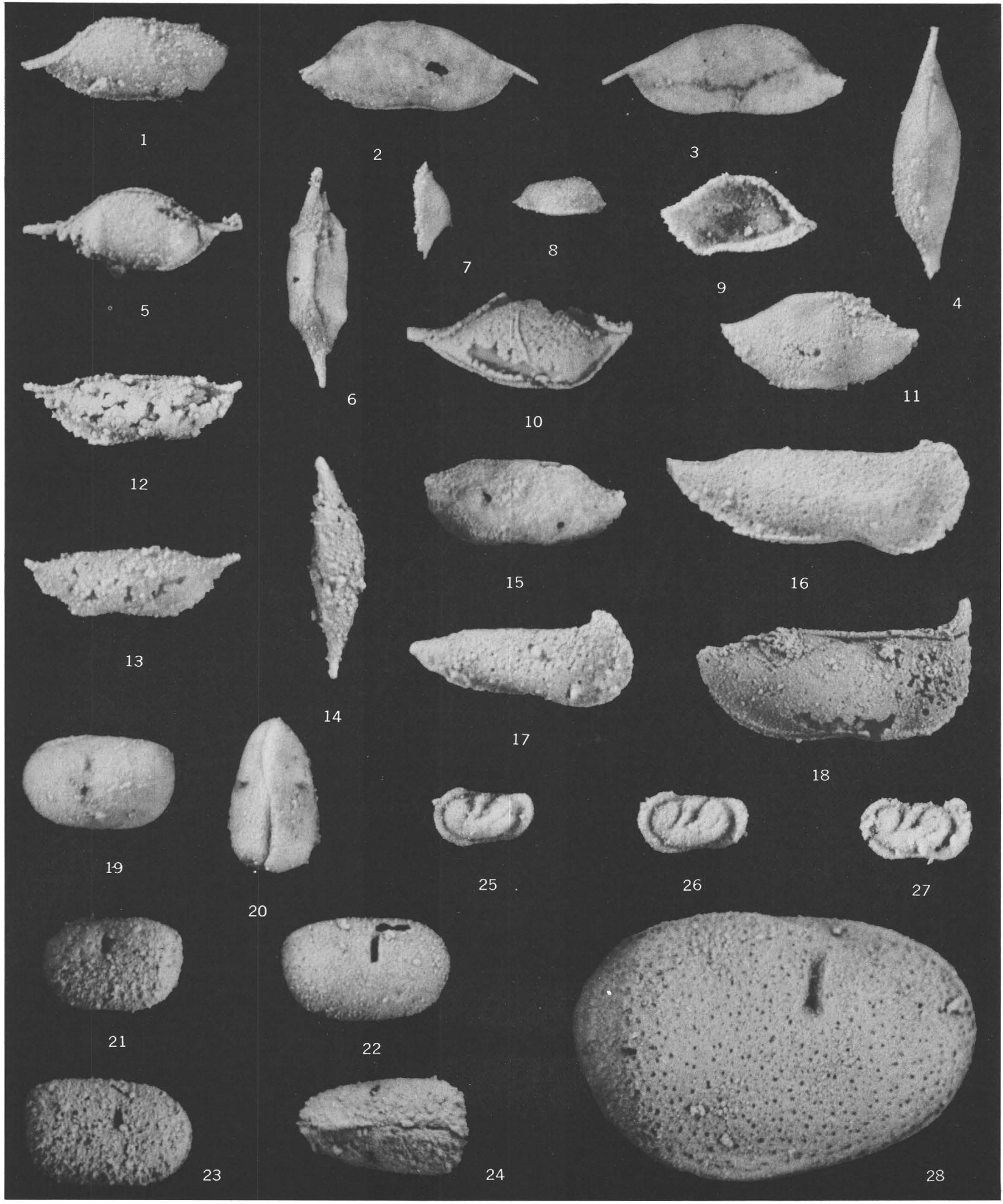

BAIRDIA, BAIRDIOLITES?, BEECHERELLA?, ACANTHOSCAPHA, RECTOBAIRDIA, SHIDELERITES, EUKLOEDENELLA, AND POLONIELLA (FRAMELLA) 


\section{PLATE 12}

FiguRES 1-3. "Tricornina" caurina n. sp. (p. 33).

Lateral, posterior, and dorsal views of right valve, holotype, GSC 29448, from the Prongs Creek Formation, Ludvigsen collection V-3.

4. Tricornina sp. (p. 34).

Broken left valve, figured specimen, GSC 29510, from the Michelle Formation, Ludvigsen collection I-3. 5-7. Bicornina sp. (p. 34).

5, 7. Left-lateral and dorsal views, figured specimen, USNM 173810, from the McCann Hill Chert, USGS collection 7037-SD.

6. Left-lateral view of carapace, figured specimen, USNM 173809, from the McCann Hill Chert, USGS collection 6492-SD.

8,9. Berounella sp. aff. B. minuta Blumenstengel, 1970 (p. 34).

Right-lateral and dorsal views, figured specimen, USNM 173811, from the McCann Hill Chert, USGS collection 7037-SD.

10,11. Bairdiocypris? sp. cf. B.? cordiformis Rozhdestvenskaya, 1959 (p. 35).

10. Right-lateral view of carapace, figured specimen, GSC 29450, from the Prongs Creek Formation, Ludvigsen collection V-3.

11. Right-lateral view of small carapace, figured specimen, USNM 173840, from the McCann Hill Chert, USGS collection 7037-SD.

12. Bairdiocypris sp. (p. 35).

Right-lateral view of carapace, figured specimen, GSC 29476, from the Prongs Creek Formation, Ludvigsen collection $\mathrm{V}-3$.

13-25. Kuresaaria blackstonensis n. sp. (p. 35).

13. Right-lateral view of small carapace, paratype, USNM 173818, from the McCann Hill Chert, USGS collection 6492-SD.

14. Interior of left valve, paratype, USNM 173816, from the McCann Hill Chert, USGS collection 7037-SD.

15. Dorsal view of carapace, paratype, USNM 173817, from the McCann Hill Chert, USGS collection 7032-SD.

16. Interior of left valve, paratype, GSC 29490, from the Michelle Formation, Ludvigsen collection II-13, showing hinge.

17. Interior of right valve, paratype, GSC 29492, from the Michelle Formation, Ludvigsen collection II-13, showing hinge and muscle scar.

18. Right view of carapace, holotype, GSC 29487, from the Prongs Creek Formation, Ludvigsen collection V-3.

19. Right valve, paratype, GSC 29491, from the Michelle Formation, Ludvigsen collection II-13.

20. Left valve, paratype, GSC 29488, from the Michelle Formation, Ludvigsen collection II-13.

21. Broken specimen, paratype, GSC 29493, from the Michelle Formation, Ludvigsen collection II13 , showing thickness of shell.

22. Interior of left valve, paratype, GSC 29489, from the Michelle Formation, Ludvigsen collection II-13, showing muscle scar and ventral stop ridges.

23. Right view of corroded carapace, paratype, USNM 173815, from the McCann Hill Chert, USGS collection 6492-SD, showing possible mural pores replaced by silica.

24, 25. Right-lateral and left-lateral views of large carapace, paratype, USNM 170343, from the McCann Hill Chert, USGS collection 6492-SD. 

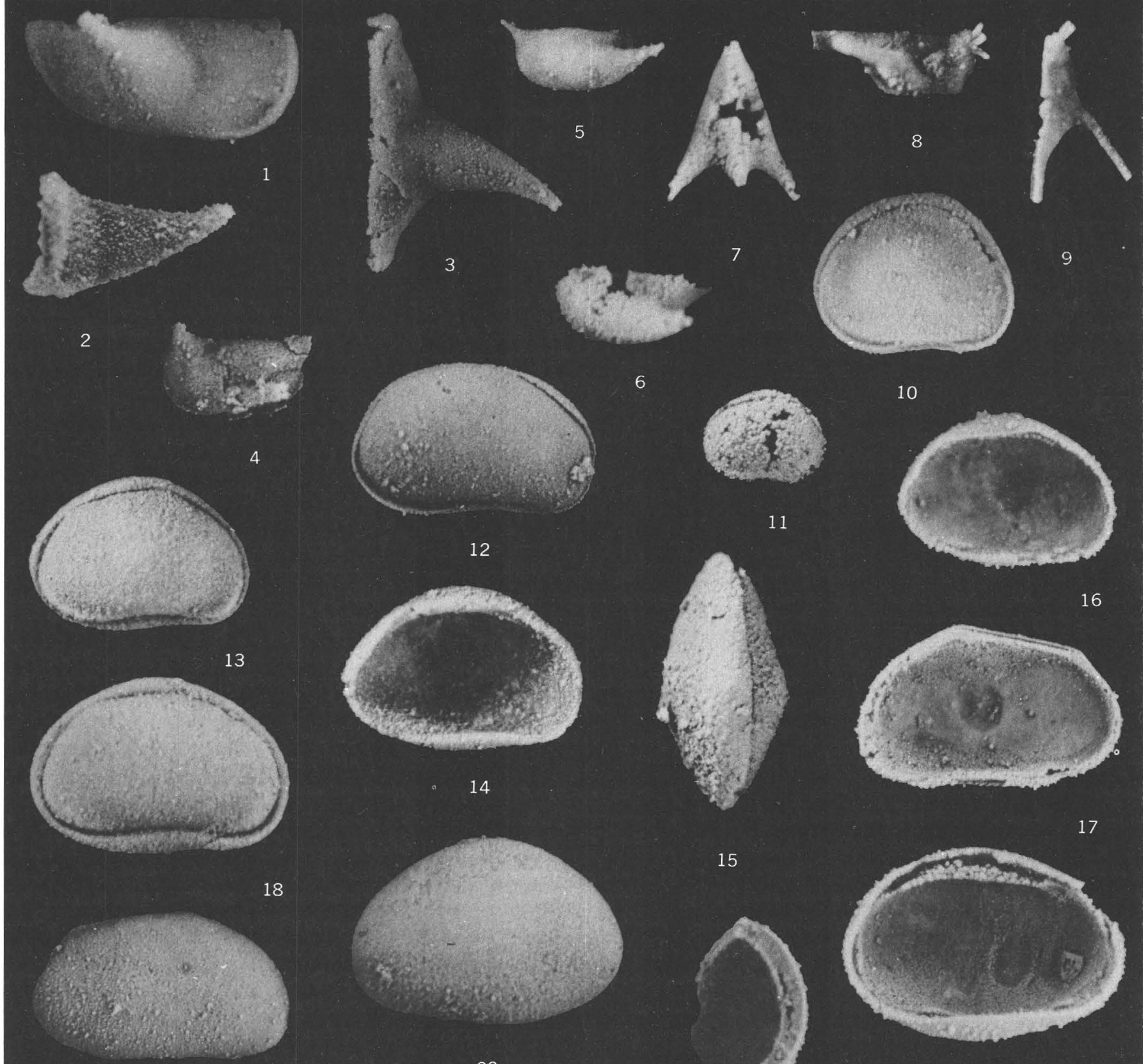

19
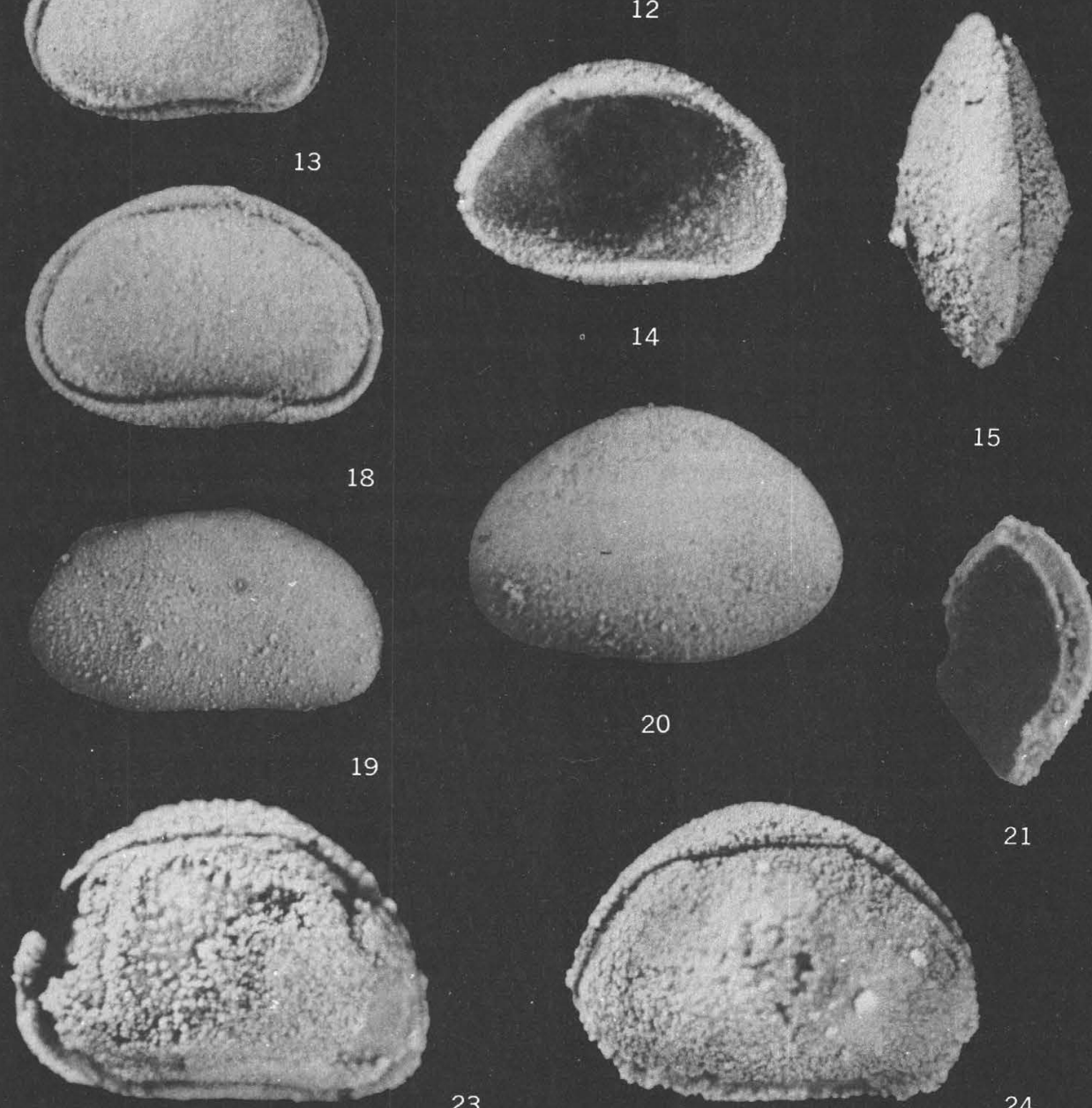

10

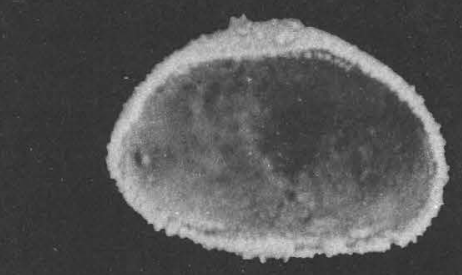

20
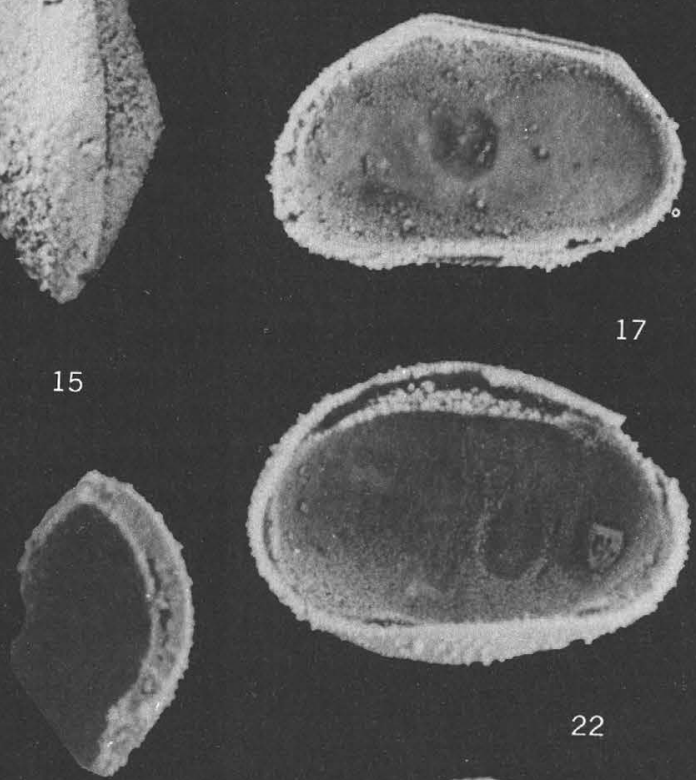

17

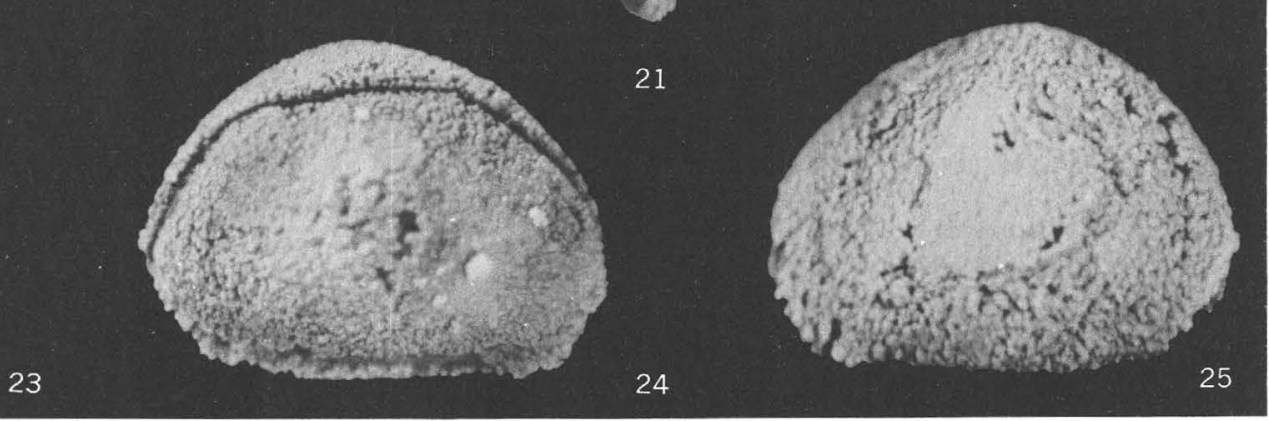

"TRICORNINA", BICORNINA, BEROUNELLA, BAIRDIOCYPRIS?, BAIRDIOCYPRIS, AND KURESAARIA 


\section{PLATE 13}

[All figures $\times 30$ ]

FIgURES 1-4. Camdenidea sp., from the McCann Hill Chert, USGS collection 7047-SD (p. 33).

1. Right valve, figured specimen, USNM 173813.

2, 3. Left-lateral and interior views, figured specimen, USNM 173814.

4. Left-lateral view of carapace, figured specimen, USNM 173812.

5-7. Praepilatina sp. aff. P. praepilata sibirica Polenova, 1970, from the McCann Hill Chert, USGS collection 7437-SD (p. 36).

5. Small right valve, figured specimen, USNM 173825 .

6. Interior of small right valve, figured specimen, USNM 173826.

7. Large left valve, figured specimen, USNM 173827.

8-11. Bairdiohealdites? scapulatus n. sp., from the McCann Hill Chert (p. 36).

8,9. Right-lateral and dorsal views of carapace, holotype, USNM 173819, USGS collection 7033SD.

10. Interior of left valve, paratype, USNM 173824, USGS collection 7037-SD, showing muscle scar.

11. Interior of left valve, paratype, USNM 173820, USGS collection 6492-SD, showing character of dorsal margin.

12-17. Voronina sp. cf. V. inventa Rozhdestvenskaya, 1962, from the McCann Hill Chert (p. 37).

12-14. Left-lateral right-lateral, and dorsal views of carapace, figured specimen, USNM 173828, USGS collection 7032-SD.

15, 16. Right-lateral and interior views, figured specimen, USNM 173829, USGS collection 6492-SD.

17. Left-lateral view of large carapace, figured specimen, USNM 173830, USGS collection 7032-SD. 


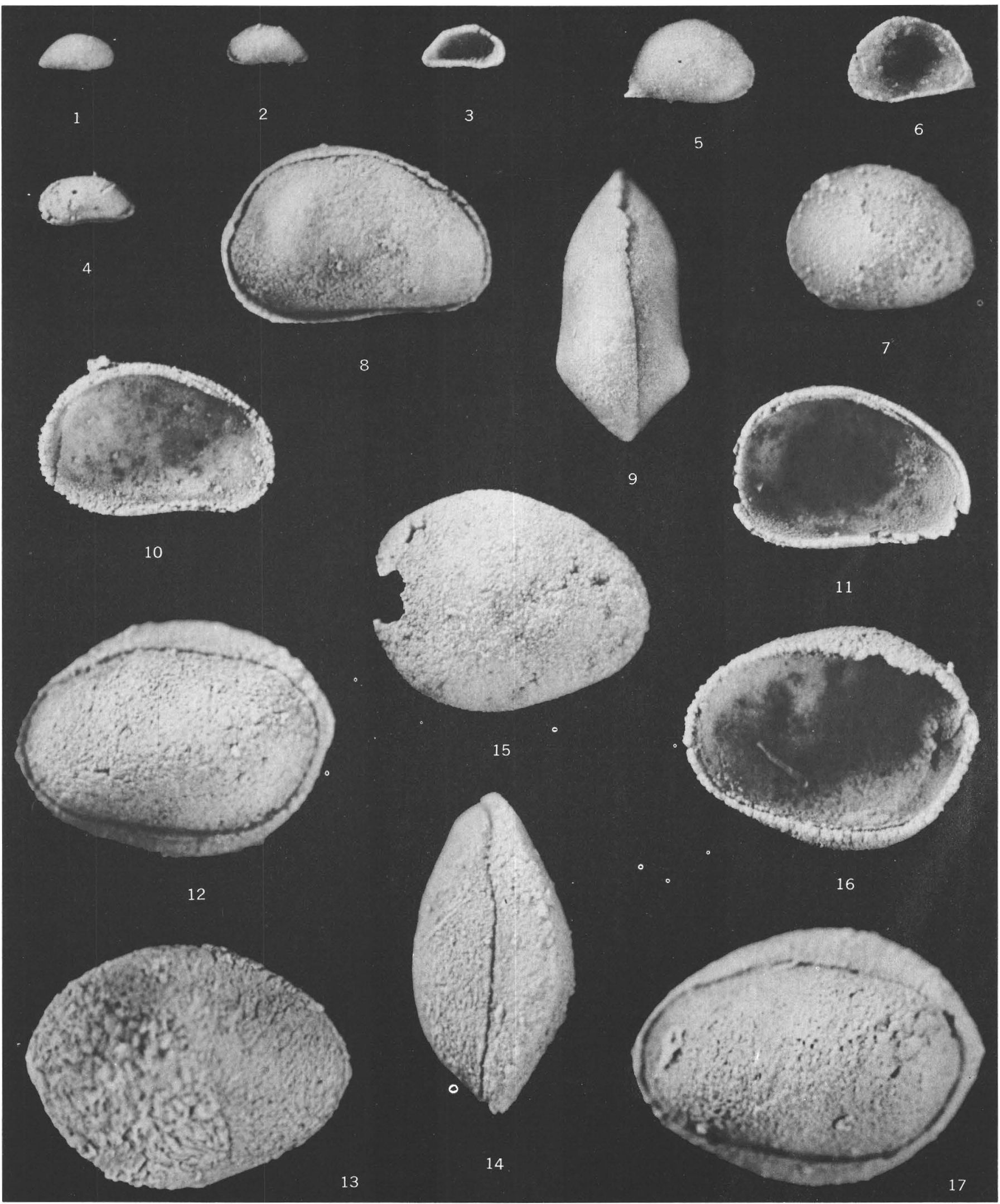

CAMDENIDEA, PRAEPILATINA, BAIRDIOHEALDITES?, AND VORONINA 


\section{PLATE 14}

Figures 1,2. Eriella? sp. (p. 39).

[All figures $\times 30$ ]

1. Right valve, figured specimen, USNM 173834, from the McCann Hill Chert, USGS collection 7037-SD.

2. Right valve, figured specimen, GSC 29452, from the Michelle Formation, Ludvigsen collection I-3.

3, 4. Microcheilinella? sp., from the Prongs Creek Formation, Ludvigsen collection V-3 (p. 39).

3. Right-lateral view of carapace, figured specimen, GSC 29515.

4. Dorsal view of carapace, figured specimen, GSC 29514.

5-11. Neocraterellina? crescentifera n. sp., from the MeCann Hill Chert, USGS collection 6492-SD (p. 39).

5,6. Right-lateral and ventral views of carapace, paratype, USNM 173836.

7. Left valve, paratype, USNM 170336.

8,9. Right-lateral and dorsal views of carapace, holotype, USNM 173835.

10. Interior of left valve, paratype, USNM 173837.

11. Interior of left valve, paratype, USNM 173838.

12-14. Cavellina (Invisibila)? sp., from the McCann Hill Chert, USGS collection 7037-SD (p. 37).

12,13. Right-lateral and left-lateral views of carapace, figured specimen, USNM 173848.

14. Interior of right valve, figured specimen, USNM 173849.

15, 16. Ostracode indet. 3 (p. 40).

15. Right-lateral view of carapace, figured specimen, GSC 29517, from the Prongs Creek Formation, Ludvigsen collection V-3.

16. Dorsal view of carapace, figured specimen, GSC 29516, from the Prongs Creek Formation, Ludvigsen collection V-3.

17, 18. Newsomites? sp. (p. 31).

Right-lateral and dorsal views of carapace, figured specimen, USNM 173847, from the McCann Hill Chert, USGS collection 7037-SD.

19. Barychilina? sp. (p. 36).

Right valve, figured specimen, GSC 29451, from the Michelle Formation, Ludvigsen collection I-3.

20. Ostracode indet. 1 (p. 40).

Broken right valve, figured specimen, GSC 29511, from the Michelle Formation, Ludvigsen collection I-3.

21. Trypetera? sp. (p. 37).

Broken right valve, figured specimen, GSC 29447, from the Michelle Formation, Ludvigsen collection II-13.

22. Ostracode indet. 2 (p. 40).

Left valve, figured specimen, USNM 173839, from the McCann Hill Chert, USGS collection 6492-SD.

23. Pachydomellid indet. 2 (p. 38).

Left valve, figured specimen, USNM 173846, from the McCann Hill Chert, USGS collection 7037-SD.

24-26. Pachydomellid indet. 1 (p. 38).

24. Left valve, figured specimen, USNM 173832, from the McCann Hill Chert, USGS collection 7037-SD.

25,26. Right-lateral and dorsal views of carapace, figured specimen, USNM 173833, from the McCann Hill Chert, USGS collection 7032-SD.

27-29. Tubulibairdia sp. (p. 38).

27, 28. Right-lateral and dorsal views of broken carapace, figured specimen, USNM 173831, from the McCann Hill Chert, USGS collection 7032-SD.

29. Right-lateral view of carapace, figured specimen, GSC 29475, from the Prongs Creek Formation, Ludvigsen collection V-3. 


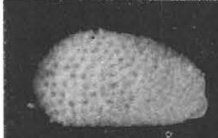

1

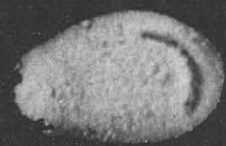

7

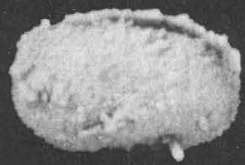

12

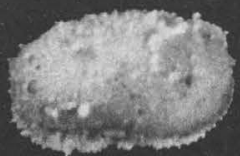

13

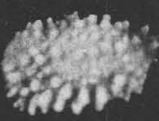

23

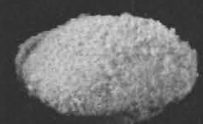

25

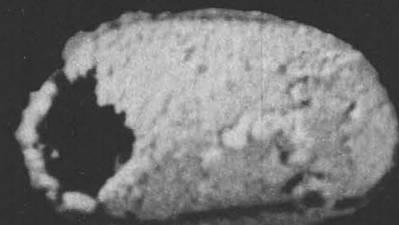

27
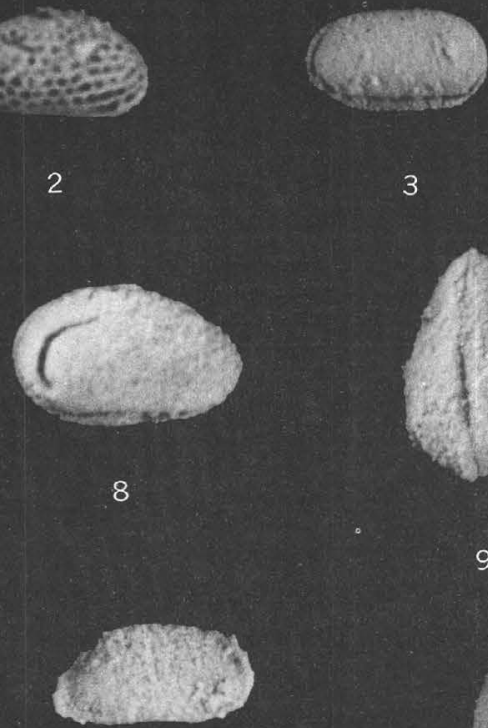

15

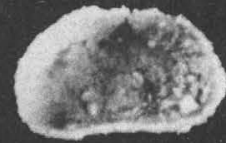

14

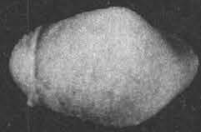

24

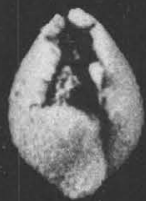

26

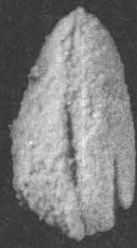

9

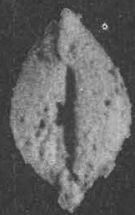

16

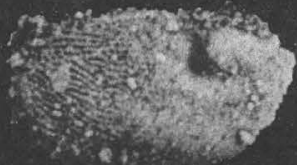

19

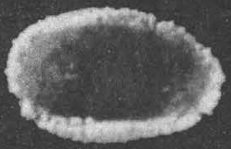

10
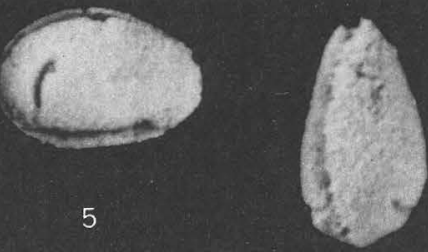

6

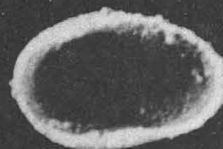

11

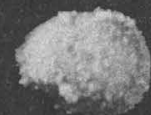

17

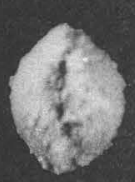

18

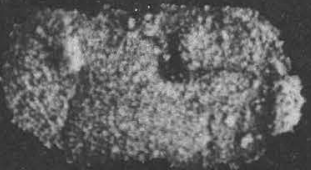

20

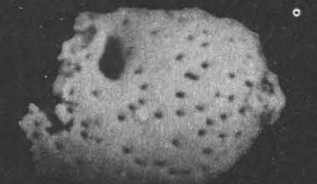

21

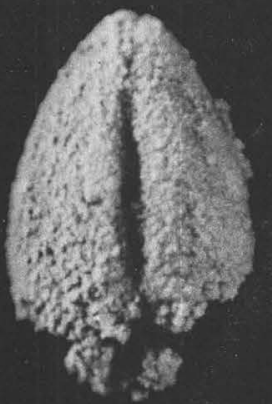

22
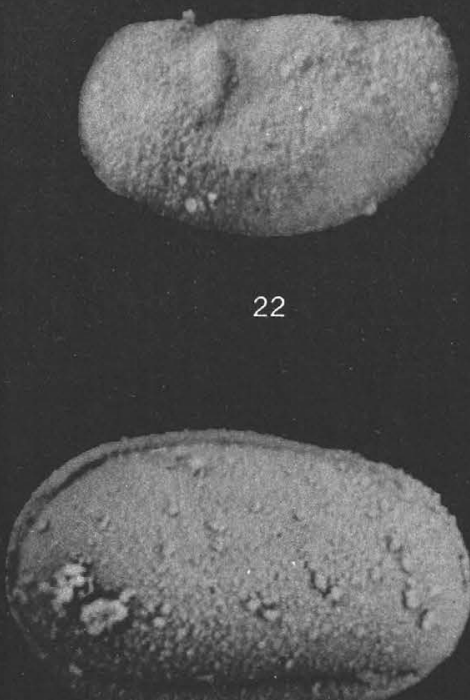

ERIELLA?, MICROCHEILINELLA?, NEOCRATERELLINA?, CA VELLINA (INVISIBILA)?, NEWSOMITES?, BAR YCHILINA?, TRYPETERA?, TUBULIBAIRDIA, AND OSTRACODES INDET 
